Maurer School of Law: Indiana University

Digital Repository@Maurer Law

Indiana Law Journal

Volume 84 | Issue 1

Article 2

Winter 2009

\title{
The Failure of Adversarial Process in the Administrative State
}

Bryan T. Camp

Texas Tech University School of Law, bryan.camp@ttu.edu

Follow this and additional works at: https://www.repository.law.indiana.edu/ilj

Part of the Administrative Law Commons, and the Dispute Resolution and Arbitration Commons

\section{Recommended Citation}

Camp, Bryan T. (2009) "The Failure of Adversarial Process in the Administrative State," Indiana Law Journal: Vol. 84 : Iss. 1 , Article 2.

Available at: https://www.repository.law.indiana.edu/ilj/vol84/iss1/2

This Article is brought to you for free and open access by the Law School Journals at Digital Repository @ Maurer Law. It has been accepted for inclusion in Indiana Law Journal by an authorized editor of Digital Repository @ Maurer Law. For more information, please contact rvaughan@indiana.edu.

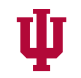

JEROME HALL LAW LIBRARY

INDIANA UNIVERSITY

Maurer School of Law
Blooming ton 


\title{
The Failure of Adversarial Process in the Administrative State $^{\dagger}$
}

\author{
BRYAN T. CAMP*
}

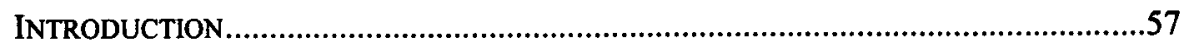

I. THE CONTEXT OF COLLECTION DUE PROCESS (CDP) .....................................58

A. TAX DETERMINATION: THE ASSESSMENT PROCESS .................................59

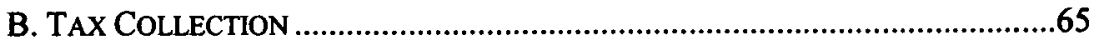

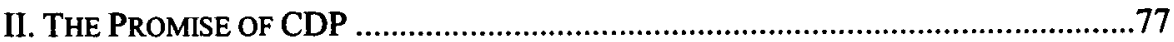

A. AS PROPOSED: THE SENATE VERSION...................................................78

B. AS ENACTED: CONFERENCE COMMITTEE MODIFICATIONS .......................79

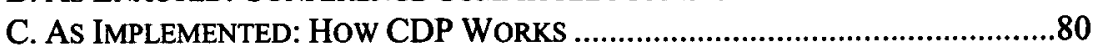

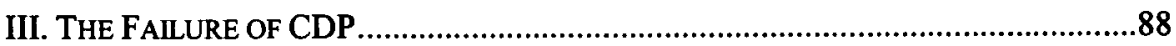

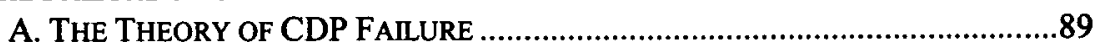

B. THE STUDY AND ITS RESULTS .....................................................111

IV. THE RULE OF LAW AND INQUISITORIAL DUE PROCESS ...................................118

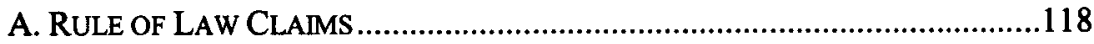

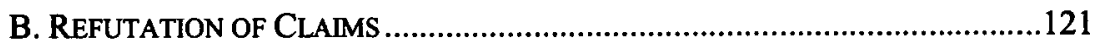

C. INQUISITORIAL DUE PROCESS .........................................................122

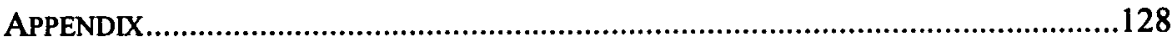

\section{INTRODUCTION}

"Distrust of the bureaucracy is surely one reason for the clamor for adversary proceedings in the United States.",

In a series of hearings in 1997 and 1998, Congress heard allegations that the Internal Revenue Service (IRS or "Service") abused taxpayers during the process of collecting taxes. ${ }^{2}$ The resulting distrust of the tax bureaucracy led Congress to create a special adversary proceeding providing for judicial review of IRS collection decisions. The proceeding is beguilingly titled "Collection Due Process" (and commonly referred to as CDP). My study of CDP's structure, operation, and of 976 court decisions issued through the end of 2006 demonstrates that CDP has not fulfilled its promise. It is instead an outstanding regulatory failure. Of the over sixteen million collection decisions made since 2000 , courts have reviewed at most 3,000 and have reversed only sixteen. That is a reversal rate of about one in a million. Adversary process is not an

+ Copyright $(02008$ Bryan T. Camp.

* Professor of Law, Texas Tech University School of Law. I am most grateful for the invaluable research assistance of Lee Franks. I am also grateful for the thoughtful comments I received on earlier drafts of this article from Les Book, Danshera Cords, Steve Johnson, Kristin Hickman, Leandra Lederman, Peter McNeilly, and Larry Schattner. I remain responsible for all errors of commission and omission.

1. Henry J. Friendly, Some Kind of Hearing, 123 U. PA. L. REV. 1267, 1279-80 (1974).

2. Bryan T. Camp, Tax Administration as Inquisitorial Process and the Partial Paradigm Shift in the IRS Restructuring and Reform Act of 1998, 56 FLA. L. REV. 1 (2004). 
effective regulatory mechanism to check government abuses in the modern administrative state.

This Article pursues two goals. First, it documents and explains CDP's failure to provide a meaningful external check on tax collection abuses. In fact CDP likely hurts those who most need its promised protection from arbitrary agency action: the working poor who risk seeing their Earned Income Tax Credit subsidies snatched away by the over-reaching tax collector. Second, this Article links CDP's failure to larger questions of the role for adversary process in the administrative state. Some commentators contend there can be no proper "rule of law" without adversarial process. ${ }^{3}$ This study of CDP proves the opposite claim: adversarial process, used in the wrong place and the wrong time, becomes a rule of deception rather than a rule of law. CDP is a failure on many levels, but an instructive failure, for it tells much about the problem of using adversarial process in the administrative state.

This Article proceeds in four parts. Because administrative law is breathtakingly parochial, the reader needs to understand the particular context of this regulatory program in order to understand the larger point it illustrates. Thus, Part I gives the conceptual overview of tax administration necessary to understand both the evaluation and critique of CDP. Part II then explains the origins and operations of CDP. Part III applies the theory of tax administration developed in Part II to larger administrative law concepts to show how CDP fails to serve its promised purpose, and how it actually harms both taxpayers and the cause of good tax administration. Part IV explores whether an inquisitorial administrative process can satisfy "rule of law" values and sketches out some ideas about how tax collection might be structured along the lines of what I term "inquisitorial due process."

\section{The Context of Collection Due Process (CDP)}

"Congress should know how to levy taxes, and if it doesn't know how to collect them, then a man is a fool to pay them." 4

Historically and conceptually, tax administration divides into two main functions: determining the correct tax liability and collecting it. ${ }^{5}$ As any entrepreneur will tell

3. See, e.g., Leslie Book, The Collection Due Process Rights: A Misstep or a Step in the Right Direction?, 41 Hous. L. REV. 1145, 1160-61 (2002) ("[J]udicial review of . . IRS collection hearings ... comprise a step in the progression of the rule of law principles that ... permeate twentieth century legal culture.").

4. Gerald Carson, The Golden Egg: The Personal income tax Where It Came FROM, How IT GREW 119 (1977) (quoting statements J.P. Morgan made in Legal Tax-Dodging Upheld by Morgan, N.Y. TIMES, June 8, 1937, at 27). Carson termed this statement "the indiscretion of a lifetime." Id.

5. Examples of the historical separation of these functions can be found in Camp, supra note 2; William T. Plumb, Tax Refund Suits Against Collectors of Internal Revenue, 60 HARV. L. Rev. 685 (1947); Joseph J. Thomdike, Reforming the Internal Revenue Service: A Comparative History, 53 ADMIN. L. REV. 717 (2001). For a defense of the conceptual separation, see Camp, supra note 2. The separation is not absolute in practice. For example, collection personnel also perform some liability determination functions in the form of 
you, figuring out what a client owes and then actually collecting it are quite different tasks. And so it is with tax administration. CDP occurs during the collection process, but one needs to understand something of both assessment and collection to appreciate how CDP fits within the tax administration structure, which has been based on this assessment/collection dichotomy since the Civil War. ${ }^{6}$

\section{A. Tax Determination: The Assessment Process}

The tax determination process culminates in an "assessment" of tax. Internal Revenue Code $\S 6201$ authorizes and requires the IRS to "assess" all tax liabilities. Section 6203 defines "assessment" as "recording the liability of the taxpayer in the office of the Secretary in accordance with rules or regulations prescribed by the Secretary." To understand CDP, one must first understand the role of assessments in tax administration.

An assessment serves two important functions in tax administration. First, it reflects the IRS's administrative adjudication of a taxpayer's tax liability for a closed set of past financial transactions. It is not simply a bookkeeping entry but rather represents the culmination of the tax determination process. Second, it allows the IRS to collect tax administratively, free of judicial supervision, until the assessment is fully paid. As such, it represents the start of a second process, tax collection. I will briefly discuss each in turn.

\section{Assessment Is an Agency Adjudication}

An assessment reflects the IRS's judgment about a taxpayer's liability but does not create the liability. Taxpayers are liable for taxes whether or not the IRS assesses them. ${ }^{8}$ The concept of a tax period is foundational to liability. Liability for income taxes arises by operation of law at the end of the applicable tax period (usually a year), at which time all transactions are deemed closed so as to present a discrete set of facts on which the liability rules operate. ${ }^{9}$ An assessment is just the application of liability

investigating and assessing I.R.C. $§ 6672$ 's Trust Fund Compliance Penalty and investigating taxpayers who have not filed any returns.

6. See Camp, supra note 2, at 37-53.

7. I.R.C. $\S 6203$ (2000). Unless otherwise noted, all citations to code sections are to the Internal Revenue Code, beginning at 26 U.S.C. $\$ 1$ (2000).

8. See I.R.C. § 6501(a) (2000) (stating that the IRS must either assess or bring proceedings in court without assessment within three years after the return is filed); see also Ewing v. United States, 914 F.2d 499, 502-03 (4th Cir. 1990) (rejecting taxpayer's argument that, prior to assessment, there can be no tax liability and therefore no "payment" of taxes).

9. See I.R.C. $\S 441$ (2000) ("[T]axable income shall be computed on the basis of the taxpayer's taxable year."); Healy v. Comm'r, 345 U.S. 278, 281 (1953) ("One of the basic aspects of the federal income tax is that there be an annual accounting of income. Each item of income must be reported in the year in which it is properly reportable and in no other.") (internal footnotes omitted); Edelson v. Comm'r, 829 F.2d 828, 834 (9th Cir. 1987) ("[T]ax liabilities, though unassessed, are deemed obligations due and owing at the close of the taxable year."). While CDP affects all types of taxes, this Article will chiefly deal with the taxation of income, which accounted for forty-four percent of net revenue in fiscal year 2006. I.R.S., DEP'T OF THE TREASURY, INTERNAL ReVEnUE SERVICE DATA BOOK, 2006, at 3 tbl.1, available at http://www.irs.gov/pub/irs-soi/06databk.pdf [hereinafter 2006 DATA BOOK]. 
rules to past facts made visible. The liability rules are the familiar rules of inclusions, exclusions, deductions, and credits found in subtitles $A$ through $E$ of the Internal Revenue Code ("Tax Code"). The past facts are made visible either by taxpayers reporting them on their returns or by the IRS discovering them through various types of audits. Either way, the assessment is distinct from the liability it reflects. ${ }^{10}$

I emphasize "judgment" because an assessment reflects the IRS's (and not the taxpayer's) judgment of what taxes are owed. Politicians, judges, and commentators often state that ours is a "self-assessment" system of tax administration. ${ }^{11}$ This claim is false as a matter of law and suspect as a matter of fact, assuming that what it really means is that taxpayers control the initial calculation of tax.

As a matter of law, assessment of a self reported liability occurs only if and when the IRS accepts a return as filed and makes the formal recordation of the resulting tax liability on its books. (These books have been kept electronically on computers since the early 1960s). ${ }^{12}$

Given that the IRS processes over 225 million tax returns each year (not including the over 1.5 billion information returns such as $1099 \mathrm{~s}$ and $\mathrm{W}-2 \mathrm{~s}),{ }^{13}$ it should come as no surprise that the IRS accepts most returns "as filed." That is, it accepts as true the self report of taxpayers-when made on properly completed forms. This decision to accept proper forms as a substitute for proper substance might seem to make the liability assessment the taxpayer's call, as a matter of fact if not of law.

But, as a matter of fact, the IRS still makes a judgment of the proper liability. ${ }^{14}$ What is misleading is that the judgment is not exercised on an individualized basis. The decision to accept taxpayer returns "as filed" is an aggregate, or bulk processing,

10. This distinction between assessment and liability is particularly important when a taxpayer pays the IRS (through withholding, for example) before the assessment period ends, but the IRS never assesses the liability. See, e.g., Lewis v. Reynolds, 284 U.S. 281, 283 (1932) (holding that expiration of assessment limitations period without assessment being recorded does not bar the Service from retaining payments already received if they do not exceed the amount which could have been-but was not-properly assessed within the limitations period). Amounts paid after the assessment period ends must be returned because they are, by definition, overpayments. I.R.C. $\$ 6401$ (a) (2000).

11. See, e.g., Montgomery v. Comm'r, 122 T.C. 1, 36 (2004) (Gerber, J., dissenting) (referring repeatedly to a "self-assessed" tax system); A Closer Look at the Size and Sources of the Tax Gap: Hearing Before the Subcomm. on Taxation and IRS Oversight of the S. Comm. on Finance, 109th Cong. 480 (2006) [hereinafter 2006 Tax Gap Hearings] (statement of Raymond T. Wagner, Jr., Chairman, IRS Oversight Commission) ("The reporting and payment of taxes by individuals and corporations is a process that begins with a self-assessment made by the taxpayer of taxes owed."); Joseph J. Darby, Confidentiality and the Law of Taxation, 46 AM. J. COMP. L. 577, 577 (1998) (stating that the tax system is "based on the principle of voluntary self-assessment"); Gary Klott, Tax Watch: Fighting IRS: Uneven Match, N.Y. TIMES, May 5, 1987, at D2 (quoting Michael Graetz, who states that the tax system is "structured as a selfassessment system"). But cf. Hibbs v. Winn, 542 U.S. 88, 100 n.3 (2004) (noting that the word "self-assessment" is not a technical term in the Code).

12. IRS Historical Studies, DEP'T OF the TrEasury, IRS Historical Fact BoOK: A Chronology: 1646-1992, at 181 (1993).

13. 2006 DATA BOOK, supra note 9, at 4 tbl.2, 37 tbl.14.

14. It is not necessarily the final judgment. The Tax Code gives the IRS at least three years to review any particular return. See I.R.C. $\$ 6501$ (2000). 
decision because it is a decision about a class of taxpayers, not an individual taxpayer. That the decision is made on an aggregate basis (treating those who fill out their forms properly as reporting the correct tax) does not make it any less an IRS decision or judgment. After all, as former Ambassador John Bolton would be happy to explain, there is no "IRS" just as there is no "United Nations."15 In both cases there is a bureaucracy whose "decisions" are simply the result of processes. ${ }^{16}$ At the IRS, those processes result in aggregate decisions, both from human-human interaction (development of regulations, for example) and also human-machine interactions (prewritten algorithms kick out "suspect" returns for audit). I shall return to this point when discussing tax collection.

Nor does the aggregate decision to accept returns "as filed" derive merely from limited resources or a Pollyanna faith in human nature. The yearly discipline of self reporting and payment cannot be divorced from the constant coercive threat of discovery and sanctions resulting from the Orwellian system of third-party information reporting and Benthamite system of audit selection. ${ }^{17}$ Without these, our tax administrators could not brag that "most countries would be thrilled to have a voluntary compliance rate of almost 84 percent." ${ }^{, 18}$ With them, assessments based on filed returns make administrative sense. The system is really just trusting that taxpayers are not fools. J.P. Morgan would approve.

\section{In 1994, Bolton said:}

The point that I want to leave with you in this very brief presentation is where I started, is that there is no United Nations. ... [I]t would be a real mistake to count on the United Nations as if it is some disembodied entity out there that can function on its own.

Democracy Now!, John Bolton in His Own Words: Bush's UN Ambassador Nominee Condemns United

Nations, http://www.democracynow.org/2005/3/31/john_bolton_in_his_own_words.

16. When asked about this statement in his April 11, 2005, confirmation hearings, Bolton explained that the U.N. is the product of actions and decisions made by its individual members and is not an organic entity. Craig Gilbert, U.N. Nominee Hit by a Barrage of Criticism; Bush Choice Bolton Grilled on Previous Statements, MiLwAUKEE J. SENTINEL, Apr. 12, 2005, at A1. People often make the same mistake of thinking of the IRS as a monolithic entity.

17. See Michel Foucault, Discipline and Punish 200-01 (Alan Sheridan trans., Vintage Books 1977) (1975) (discussing Bentham's theory underlying the Panopticon and the link between systems of punishment and internalized individual discipline); Camp, supra note 2, at 8-11 (describing IRS systemic matching program based on third party information returns).

18. 2006 Tax Gap Hearings, supra note 11, at 160 (statement of Mark J. Mazur, Director, Research, Analysis, and Statistics, IRS). The point is well illustrated by the statistics:

The IRS has estimated that individuals whose wages are subject to withholding report 99 percent of their wages for tax purposes. In contrast, self-employed individuals who formally operate non-farm businesses are estimated to report only about 68 percent of their income for tax purposes. Even more alarming, selfemployed individuals operating businesses on a cash basis report just 19 percent of their income to the IRS.

Id. at 95 (statement of J. Russell George, Treasury Inspector General for Tax Administration) (footnotes omitted). 


\section{Assessment Permits Collection, Precludes Review}

An assessment marks the end of one process-tax determination-and the beginning of another-administrative tax collection. A proper assessment enables the tax lien created by $\S 6321$ to arise. It allows the IRS to begin seizing taxpayer property under its levy authority in $\S 6331$. Finally, and most critically, a proper assessment opens up the $\S 6502$ collection period, which gives the IRS a whopping ten years to collect the tax administratively. The corollary is that if no proper assessment is made within the applicable assessment limitations period in $\$ 6501$ (generally three years) the liability itself is extinguished. The assessment limitations period acts as a statute of repose. $^{19}$

Once an assessment is recorded, it not only permits administrative collection action; it also bars judicial review of the liability decision until the amount assessed is paid. A strong pay-first rule has been integral to tax administration since 1867 when Congress enacted the Anti-Injunction Act to provide that "[N]o suit for the purpose of restraining the assessment or collection of any tax shall be maintained in any court by any person, whether or not such person is the person against whom such tax was assessed." Supreme Court has consistently interpreted "the principal purpose of this language to be the protection of the Government's need to assess and collect taxes as expeditiously as possible with a minimum of preenforcement judicial interference, 'and to require that the legal right to the disputed sums be determined in a suit for refund." 21 The payfirst rule treats the assessment as a court judgment, as the Supreme Court explained in 1935:

The assessment is given the force of a judgment, and if the amount assessed is not paid when due, administrative officials may seize the debtor's property to satisfy the debt. ... Thus, the usual procedure for the recovery of debts is reversed in the field of taxation. Payment precedes defense, and the burden of proof, normally on the claimant, is shifted to the taxpayer. The assessment supersedes the pleading, proof, and judgment necessary in an action at law, and has the force of such a judgment. The ordinary defendant stands in judgment only after a hearing. The

19. United States v. Powell, 379 U.S. 48, 59 (1964) (Douglas, J., dissenting) (footnote omitted); Ill. Masonic Home v. Comm'r, 93 T.C. 145, 149-50 (1989) (explaining the court's prior holding that the expiration of the period of limitations on assessment extinguishes liability). See generally, Bryan T. Camp, Tax Return Preparer Fraud and the Assessment Limitation Period, 116 TAX NoTES 687 (2007) (tracing the history of assessment limitation statutes from 1862 to show their operation as statutes of repose).

20. I.R.C. $\$ 7421$ (a) (2000). The Act plugged a hole in the "pay first, litigate later" regime created by the administrative reform provisions of the 1866 Revenue Act, ch. 184, 14 Stat. 98 . Section 19 of the 1866 Act set up the refund scheme now codified at I.R.C. $\S 7422$ (2000), but did not prohibit taxpayers from enjoining collection on the ground that the assessment was wrong. The pay-first rule is carried over into other statutes including, for example, the Declaratory Judgment Act. See 28 U.S.C. § 2201(a) (2000).

21. Bob Jones Univ. v. Simon, 416 U.S. 725, 736 (1974) (quoting Enochs v. Williams Packaging \& Navigation Co., 370 U.S. 1, 7 (1962)), quoted in Hibbs v. Winn, 542 U.S. 88, 103 (2004). The Court has upheld the pay-first rule against a due process challenge. Phillips v. Comm'r, 283 U.S. 589 (1931). 
taxpayer often is afforded his hearing after judgment and after payment, and his only redress for unjust administrative action is the right to claim restitution. ${ }^{22}$

Before 1924, there was no exception to the Anti-Injunction Act or the strong pay-first rule it supported. Once the IRS disagreed with a taxpayer's return, there was simply no recourse to the courts until after the taxpayer paid what the Service demanded, even if excessive. This rule was widely perceived as unfair. ${ }^{23}$ Despite the best efforts of the IRS and Congress to provide extensive internal review, distrust of the bureaucracy led to a clamor for adversary process.

In 1924, Congress responded to the clamor by creating a partial exception to the Anti-Injunction Act for situations where the Service disagreed with the taxpayer's reported tax liability. This exception allowed taxpayers an adversary procedure in which to seek pre-assessment judicial review in a specialized tribunal-then called the Board of Tax Appeals and now called the Tax Court-for disagreements between them and the IRS over the proper tax liability. ${ }^{24}$ It was called the deficiency procedure.

The deficiency procedure is available only when the IRS determines a "deficiency" of reported tax. "Deficiency" is a term of art; it is basically the difference between the proper amount of tax and the tax reported and consented to by the taxpayer. If a taxpayer fails to report any tax, either by filing a return with zeros or by failing to file a return, then the reported tax is deemed zero. ${ }^{26}$

Under the deficiency procedure, the IRS must give taxpayers a notice of the administrative liability decision through a document called the "Notice of Deficiency." This document serves multiple purposes: it is the official notice to the taxpayer of the amount and type of tax owed, it is the necessary and sufficient prerequisite for Tax Court jurisdiction (often called the "ticket to the Tax Court" ${ }^{\text {"27 }}$ ), and it frames the issues subject to review. ${ }^{28}$

22. Bull v. United States, 295 U.S. 247, 260 (1935); see also Flora v. Comm'r, 362 U.S. $145(1960)$ (holding that the full payment of tax is required before a federal court will have jurisdiction over the refund suit); Cheatham v. United States, 92 U.S. 85, 89 (1875) ("[P]ayment of the tax claimed ... [is] a condition precedent to a resort to the courts by the party against whom the tax is assessed.").

23. See Robert H. MONTGOMERY, InCOME TAX Procedure 173-77, 235-38 (1921).

24. Revenue Act of 1924 , tit. $9, \S 900,43$ Stat. $253,336-38$. This description is somewhat simplified. The Board of Tax Appeals was widely viewed as an administrative office and not a "true" court. But it did provide independent third-party review in an adversarial forum. It served the same function as a court and eventually Congress changed the form to match the function it was already performing.

25. The deficiency procedure is codified at I.R.C. $\$ \S 6211-6216(2000)$, and "deficiency" is defined in $\S 6211$. Note that this exception is also available only for income, estate, and gift taxes. Note too that the concept of deficiency has nothing to do with payment. A taxpayer who reports the proper tax, but does not pay it, has an underpayment, not a deficiency.

26. Treas. Reg. 301.6211-1(a) (amended 1995); Taylor v. Comm'r, 36 B.T.A. 427, 429 (1937) (stating that the IRS has to use deficiency procedures when determining the tax of a nonfiler).

27. Scar v. Comm'r, 814 F.2d 1363, 1372 (9th Cir. 1987) (Hall, J., dissenting).

28. Professor Leandra Lederman has reviewed these three functions. See Leandra Lederman, "Civil"izing Tax Procedure: Applying General Federal Learning to Statutory Notices of Deficiency, 30 U.C. DAVIS L. REV. 183, 203 (1996). 
Once a taxpayer receives the Notice of Deficiency, I.R.C. $\S 6213$ allows the taxpayer (generally) ninety days to seek review of the liability determination from a neutral third-party tribunal. Only after the ninety days (or the conclusion of the Tax Court case if the taxpayer timely petitions for review) may the IRS assess. Once the assessment is made, however, the opportunity for pre-payment judicial review of the liability determination is lost because, with some exceptions not relevant here, the Anti-Injunction Act and the pay-first rule apply. Thus it is no surprise that about ninety percent of the taxpayers who receive a Notice of Deficiency and who seek judicial review of the IRS liability determination choose the Tax Court prepayment option and do not simply pay the tax and file a refund suit. ${ }^{29}$

It is important to emphasize that the deficiency procedure does not extend to situations where taxpayers merely underpay their self reported liabilities and then later want to contest the very liability they reported. ${ }^{30}$ Most of the federal income tax liabilities of individuals that the IRS seeks to collect arise from an underpayment of self-reported liabilities and not from the refusal to pay an asserted deficiency. ${ }^{31}$ This has important implications for collection policies.

In sum, the assessment marks the point after which (a) the IRS can use its administrative collection powers and (b) taxpayers cannot obtain judicial review of the liability determination until the assessment is fully paid. The next Part more fully explains the administrative collection process.

29. The most recent attempt to count tax cases comparatively was for fiscal year 1987. See William F. Nelson \& James J. Keightly, Managing the Tax Court Inventory, 7 VA. TAX REV. 451,453 (1988). There is little reason to think the relative percentages have changed.

30. This situation could arise, for example, when taxpayers seek to amend their returns and the IRS rejects the proposed amended returns. See e.g., Koch v. Alexander, 561 F.2d 1115 (4th Cir. 1977) (taxpayer reported zero liability on amended return when original return showed $\$ 20,000$ ); Goldstone v. Comm'r, 65 T.C. 113 (1975) (IRS has no duty to accept amended returns once a valid original return is filed). Nor does the deficiency procedure apply to employment taxes, which account for over one-third of gross tax collections. Those taxes, imposed by I.R.C. $\S 3111$ (2000) on employers for the privilege of employing workers, are not included in the definition of "deficiency" in $\S 6211$. Employment taxes have increased in importance since 1960, rising to just over eleven percent of all taxes collected in fiscal year 1960 to almost thirty-three percent in fiscal year 2006. 2006 DATA BOOK, supra note 9, at 1415 tbl.6.

31. There is no easily accessible public data on this point. I know it from my own studies while working in the Office of Chief Counsel. However, one can fairly infer it from the various other available data. See 2006 DATA BooK, supra note 9, at 23 tbl.9 (showing that less than one percent of all returns were audited in fiscal year 2006); id. at 41 tbl.16 (showing that just seventeen percent of reported liabilities on delinquent returns are paid with the return). In addition, taxpayers who self reported their liabilities made up nearly fifty percent of the administrative CDP hearing requests in fiscal year 2004. U.S. GOV'T ACCOUNTABILITY OFFICE, GAO-07-112, TAX ADMINISTRATION: LITTLE EVIDENCE OF PROCEDURAL ERRORS IN COLLECTION Due Process APPEAL CASES, BUT OPPORTUNITIES EXIST To IMProve THE Program 28 (2006), available at $\mathrm{http}: / / \mathrm{www}$.gao.gov/new.items/d07112.pdf [hereinafter GAO 2006 CDP STUDY]. 


\section{B. Tax Collection}

Collecting tax is a process, not an event. The goal is to resolve unpaid liabilities, either by collecting the full amount from those taxpayers who can pay (but do not want to), or by agreeing to a collection alternative for those taxpayers who cannot immediately pay in full.

At any point in the collection process, taxpayers can seek an alternative to immediate full payment. The main alternatives are (1) installment agreements, where a taxpayer fully pays the liability (and interest) over time; ${ }^{32}(2)$ offers-in-compromise (OICs), where the IRS forgives an agreed-upon percentage of the liability and the taxpayer pays the compromised amount either at once or in installments; ${ }^{33}$ and (3) designation as "currently not collectible"(CNC). ${ }^{34}$ This last alternative puts a hold on most collection activity but leaves the assessment on the books. ${ }^{35}$ If later information (such as a tax return showing increase in income) shows that the taxpayer has assets to pay the liability, collection resumes. ${ }^{36}$ If a taxpayer has no assets and no prospects, the IRS writes off the account.

\section{Tools of the Collection Trade}

Understanding the collection process is easier once one understands the tools of the trade, or at least two of them. The IRS has three great collection tools: the offset power, the tax lien, and the levy. Since offset power does not trigger CDP, I will just note it. $^{37}$

32. See I.R.C. $\$ 6159(2000)$.

33. See I.R.C. $\$ 7122(2000)$.

34. The statutory authority for CNC status derives from the abatement authority, see I.R.C. $\S 6404$ (c) (2000), which gives the IRS the discretion to abate account balances where "the administration and collection costs involved would not warrant collection of the amount due." Id. This language was added in 1954 to "codify the practice of a number of years adopted under the general administrative authority of the Department." H.R. REP. No. 83-1337, at 412 (1954); see also S. REP. No. 83-1622, at 581 (1954) (same language).

35. It stops liens and levies but does not keep the IRS from offsetting a future year's overpayment against the prior year's underpayment. Under the former practice, collection employees who did not believe a liability could be economically collected filled out a Form 53 to request an abatement of the assessment and to record the basis for their belief so they would not be held personally responsible for the failure to collect that assessed tax. See Treas. Reg. Art. 1303 (1926); Carlin v. United States, 100 F. Supp. 451, 454 (Ct. Cl. 1951); Kroyer v. United States, 55 F.2d 495, 496 (Ct. Cl. 1932); Sugar Run Coal Mining v. United States, 21 F. Supp. 10, 11 (E.D. Pa. 1937). From the Form 53 procedure, the IRS has developed a collection policy. See I.R.S., INTERNAL REVENUE MANUAL $\$$ 5.16.1.1, available at http://www.irs.gov/irm/ [hereinafter INTERNAL REVENUE MANUAL]. The IRS now accomplishes the same result by inputting a computer Transaction Code 530, which simply puts a hold on the account. Id.

36. There are also other collection alternatives, such as bankruptcy, or discharging property from the tax lien, see I.R.S. Chief Couns. Notice CC-2003-016 (May 29, 2003), available at $\mathrm{http} / / / \mathrm{www}$.unclefed.com/ForTaxProfs/irs-ccdm/2003/cc-2003-016.pdf(reviewing options for collection), but the three listed above are far and away the most common.

37. The authority to offset comes both from statutory and common law. See I.R.C. $\S 6402$ (2000); United States v. Munsey Trust, 332 U.S. 234, 239 (1947). The offset tool is another 
The tax lien arises automatically under I.R.C. $\S 6321$ once the IRS properly assesses a liability, sends the taxpayer notice and demand for payment, and the taxpayer fails to pay. ${ }^{38}$ Once it arises, it attaches-like virtual "Pay Me" sticky notes dropping from the sky - on all property the taxpayer has or later acquires. ${ }^{39}$ If there are other liens on the property, the liens get paid off in order of their perfection-a "first in time, first in right" rule-and for this purpose the tax lien is deemed to be perfected as of the date the liability it relates to was assessed. ${ }^{40}$

When it first arises, the tax lien is "secret" in that there is no public record of its existence. In order to protect certain creditors, Congress long ago decided that, although the tax lien may exist and be perfected on all property of the taxpayer as of the assessment date, it cannot take priority against four types of competing creditorsknown as the "four horsemen"- until such time as the IRS makes it visible by properly filing a Notice of Federal Tax Lien (NFTL). ${ }^{41}$ Once revealed by the NFTL, the tax lien is good against almost all comers (the few exceptions are listed in $\$ 6323(\mathrm{~b})$ ) for the jurisdiction in which it is filed. ${ }^{42}$ For example, if a taxpayer takes out a home equity loan and the bank properly files its security interest before the IRS files the NFTL, the bank's lien takes priority over the tax lien.

The tax lien is often misunderstood. What confuses many folks is the relation between the tax lien and the NFTL. There is only one tax lien, although there may be multiple NFTLs, depending on how much property the taxpayer has and in what locations. Even those involved in tax administration get confused. For example, a Government Accountability Office (GAO) report recently asserted that the "IRS exercises this power when it files a federal tax lien against the property of a

example of an aggregate collection decision. Taxpayers in financial straits may ask to bypass the offset, but they must convince an individual employee to allow the refund to issue. See I.R.S. Field Serv. Advice Mem. 200213012 (Mar. 29, 2002) (describing this system and its limitations).

38. I.R.C. $\S 6321$ (2000). This section does not specify a time after which a taxpayer has failed to pay the tax for purposes of triggering the tax lien. However, another section gives the taxpayer ten days to pay before "it shall be lawful for the Secretary to collect such tax ... by levy ...."I.R.C. $\$ 6331$ (2000). The penalty imposed for a failure to pay is triggered only after twenty-one days from the notice and demand (ten days when the tax liability demanded equals or exceeds $\$ 100,000$ ). I.R.C. $\$ 6651$ (a)(3) (2000). As a practical matter, since the tax lien is retroactive to the date of assessment and since it takes much longer than twenty-one days before the IRS reacts to an unpaid account, the exact time period is of little consequence.

39. Glass City Bank v. United States, 326 U.S. 265, 268-69 (1945) (holding that a federal income tax lien attaches to later-acquired property).

40. United States v. City of New Britain, 347 U.S. 81, 87-88 (1953). "Perfected" means that the lien identifies the lienor, the amount claimed, and the property subject to the lien. Id. at 84. The IRS wins a tie. See United States v. McDermott, 507 U.S. 447, 453-55 (1993) (holding that a federal tax lien gets priority over simultaneously attaching, competing liens).

41. The four horsemen are purchasers for value, mechanics lienors, holders of security interests, and judgment lien creditors. See I.R.C. $\S 6323$ (a) (2000). This rule protects, for example, someone who would otherwise have paid full price for property encumbered by the tax lien. See e.g., Middlesex Sav. Bank v. Johnson, 777 F. Supp. 1024 (D. Mass. 1991) (applying the statutory lien rules to variety of competing creditors).

42. I.R.C. $\S 6323(\mathrm{~b})$. The NFTL makes the lien visible against all personalty once the IRS files it in the state of the taxpayer's principal residence or place of business. I.R.C. $\S$ $6323(f)(1)(A)(i i)$. But to make it visible for realty, the NFTL must be filed in the state or county (depending on local laws) where the realty is located. $\S 6323(\mathrm{f})(1)(\mathrm{A})(\mathrm{i})$. 
taxpayer." 43 That is wrong. The IRS does not "file a tax lien," and the NFTL cannot attach to anything because the NFTL is not the lien. The NFTL just makes the lien visible and, hence, good against the four horsemen. In short, the NFTL brings the tax lien to light, not to life.

The third tool, levy, is also often misunderstood. Section 6331 defines this tool as "the power of distraint and seizure by any means" to collect an unpaid tax liability. ${ }^{44}$ This is what the term "levy" means: the power to take any property of the taxpayer to satisfy a properly assessed and unpaid tax liability. ${ }^{45}$ Section 6331 (d) requires the IRS to give the taxpayer a general notice of its intent to use this tool at least thirty days before making the first levy. ${ }^{46}$ Historically, the purpose of that notice was to give the taxpayer an opportunity to approach the IRS and resolve the account before the IRS seized property. At no time did the notice tell the taxpayer exactly what property the IRS planned to seize; it was just a shot across the bow, issued long before the IRS even knew whether the taxpayer had any assets worth seizing.

A levy is often confused with a lien, but they are separate tools. First, the IRS must act to attach a levy to specific property, whereas the lien attaches by operation of law. Second, levies mostly operate only on existing property, whereas the tax lien attaches to all future acquired property as well as existing property. ${ }^{47}$ Most importantly,

43. U.S. GOV'T ACCOUNTABILITY OFFICE, GAO-05-26R, OPPORTUNITIES TO IMPROVE TIMELINESS OF IRS LIEN RELEASES 1 (2005), available at http://www.gao.gov/new.items/d0526r.pdf. Even the Treasury's Acting Deputy Inspector General for Audit made the same error. See TREASURY INSPECTOR GEN. FOR TAX ADMIN., REFERENCE No. 2004-30-086, FISCAL YEAR 2004 STATUTORY REVIEW OF COMPLIANCE WITH LIEN DUE PROCESS PROCEDURES (2004), available at http://www.treasury.gov/tigta/auditreports/2004reports/200430086fr.pdf ("[T] he IRS has the authority to attach a claim to the taxpayer's assets, called an NFTL, for the amount of the unpaid tax liability.").

44. I.R.C. $\$ 6331(b)(2000)$.

45. For reasons unknown to me, the IRS gives the term "levy" a different meaning in its internal guidance. The IRS distinguishes between a "levy" and a "seizure," whereas the Code makes no such distinction. In Service jargon, a "seizure" is what is done to something that can be sold, usually tangible realty or personalty, while a "levy" is done to something that cannot be sold, generally intangible property such as payments due the taxpayer from a third party, or money. See generally INTERNAL REVENUE MANUAL, supra note 35, at chs. 5.10, 5.11 ("Seizure and Sale" \& "Notice of Levy"). That distinction is not evident from the statute or from its history, which the IRS admits. Id. at $\S 5.11 .1 .1 .2$ ("There is no legal distinction between levy and seizure."). Note that the GAO interprets the distinction between "levy" and "seizure" differently. It believes that the Service "differentiates between the levy of assets in the possession of the taxpayer (referred to as 'seizure') and the levy of assets, such as bank accounts and wages, which are in the possession of third parties, such as banks or employers (referred to as a 'levy')." U.S. GEN. ACCOUNTING OFFICE, GAO-02-674, TAX ADMINISTRATION: IMPACT OF COMPLIANCE AND COLLECTION PROGRAM DECLINES ON TAXPAYERS 6 n.5 (2002), available at http://www.gao.gov/new.items/d02604.pdf. The GAO gives no citation or reason for why it believes that to be the Service's distinction and I do not think the GAO is correct, but the main point is that the Code contains no distinction; the power to "levy" is the power to "seize."

46. I.R.C. $\S 6331(\mathrm{~d})(2)$.

47. The only levy that operates continuously is a wage levy. See I.R.C. $\S 6331$ (e). As to the ability of the lien to attach to future acquired interests, see United States v. McDermott, 507 U.S. 447, 453 (1993). 
Congress has exempted certain types of property from levy, whereas the tax lien attaches to all property. For example, while $\S 6334(a)(3)$ prevents the IRS from seizing and selling the first $\$ 3,125$ worth of books or tools, those items still have the virtual "Pay Me" sticky note of the tax lien attached to them. ${ }^{48}$

The two tools also operate independently. For example, the Service can levy property owned by the taxpayer, even if the tax lien no longer attaches to that property (such as when the IRS mistakenly releases the lien). ${ }^{49}$ Similarly, the lien alone supports a levy, even if the property being seized is no longer owned by the taxpayer (such as when the taxpayer deeds property to a family member or when a bank sets off a checking account against a mortgage loan). ${ }^{50}$

\section{The Bulk Processing Nature of Modern Tax Collection}

The IRS employs its collection tools in a three-stage collection process to collect or resolve some 5.5 million unpaid accounts each year. ${ }^{51}$ The three stages are: (1) the Notice stage, (2) the Automated Collection System (ACS) stage, and (3) the Collection Field Function (CFf) stage. To the extent that a delinquent account is not resolved at one stage, it moves to the next. The first two stages are highly automated, relying heavily on aggregate collection decisions applied to the vast majority of accounts. Not until the CFf stage does any IRS employee go mano a mano with a delinquent taxpayer. That is the only stage where a specific account is assigned to an individual IRS employee (a Revenue Officer), who has significant latitude and discretion on how to collect the amount owed. The third stage occurs some two or three years after the assessment, and the delay in trying a "personal touch" has long been criticized as poor collection practice. ${ }^{52}$ But it is a reasonable choice when the task is trying to collect millions of unpaid accounts with only a few thousand employees. Computers come cheap. Humans are costly. I shall describe each stage in turn, emphasizing both the idea of bulk processing and the idea that the "collection tools" described above are used as much to bring taxpayers into discussions as to collect dollars.

48. I.R.C. $\S 6334(a)(3)$ (2000); see Popky v. United States, 326 F. Supp. 2d 594, 604 (E.D. $\mathrm{Pa}$. 2004) (holding that a tax lien remained attached to assets exempt from levy, so the government could claim priority to sell proceeds once the assets were sold).

49. The Service is authorized to levy either "all property and rights to property (except such property as is exempt under $\S 6334$ ) belonging to such person or on which there is a lien provided in this chapter ...."). I.R.C. § 6331(a) (emphasis added).

50. See United States v. Bank of Celina, 721 F.2d 163, 168 (6th Cir. 1983).

51. 2006 DATA BoOK, supra note 9, at 41 tbl.16.

52. See NAT'L TAXPA YER ADVOCATE, I.R.S., 2004 ANNUAL REPORT TO CONGRESS 232-42 (2004), available at http://ftp.irs.gov/irs-utl/ntafy2004annualreport.pdf [hereinafter 2004 TAXPAYER ADVOCATE REPORT]; U.S. GEN. ACCOUNTING OFFICE, GAO/GGD-94-2, TAX administration: IRS Can Do More to Collect TaXes labeled "Currently Not COLLECTIBLE" (1993) (critiquing the lack of a "personal touch" collection practice). 


\section{i. The Notice Stage}

The Notice stage is worked out of centralized campuses (formerly known as "Service Centers") and brings in over two-thirds of total dollars collected. ${ }^{53}$ What happens here is that computers automatically send out a series of Notices and Demands for Payment to taxpayers at their last known addresses. ${ }^{54}$ The automation cannot be overemphasized. No human hand writes a line. No human tongue licks an envelope. No human eye reviews an account beforehand. Most importantly, no human brain makes any individualized decision about what notice to send.

The Notice stage is an excellent example of the distinction between aggregate and individualized decision making. For example, $\S 6321$ requires only one Notice and Demand for payment before the tax lien arises, and $\S 6331$ (d) requires only a second Notice (of Intent to Levy) before the Service may seize assets. Nonetheless, the IRS has made the aggregate decision that for this class of taxpayers (those who have not fully paid their assessed tax), additional demands for payment beyond those two minima will often resolve the account. The computer sends non-business taxpayers four notices and business taxpayers three notices, spaced five weeks apart. No individual campus employee decides this for each account; it is an institutional decision made for the bulk processing of accounts receivable.

On reflection, one might think the decision to send all notices to all taxpayers makes little sense for some subgroups, and makes no sense at all for many individuals. For example, taxpayers whose assessment is based on their return "as filed" know full well that an unpaid tax liability exists. Heck, they reported it. Similarly, individual taxpayers who lose their pre-assessment litigation in Tax Court have ample notice of where the assessed amount of tax liability comes from. So while the first notice perhaps serves the purpose of letting the taxpayer know that the IRS is now ready and willing to receive the payment, it is difficult to think of any purpose served by additional notices not required by statute (and it is difficult to think why the statute should require multiple notices in such situations). But it does not matter; to make individualized decisions about which taxpayers should get what notices would involve the time and attention of human beings, which is very expensive. The cost of identifying and exempting those subgroups and individual taxpayers from the Notice

53. Of the $\$ 40.8$ billion collected in fiscal year $2006, \$ 28.7$ billion came from the Notice stage. 2006 DATA BooK, supra note 9, at 41 tbl.16.

54. While the Service has at times attempted to reach out with telephone calls rather than rely on written notices, resource constraints have pretty much squelched this approach. See TREASURY INSPECTOR GEN. FOR TAX ADMIN., REFERENCE No. 2006-30-055, TRENDS IN COMPLIANCE ACTIVITIES THROUGH FISCAL YEAR 200523 (2006), available at http://www.ustreas.gov/tigta/auditreports/2006reports/200630055fr.pdf [hereinafter 2005 TRENDS REPORT]. Recent attempts to farm out collections to private collection firms are one response to this trend. See House Members' Letter to Everson Calls for Halt to IRS Privatization Plans, TAX NOTES TODAY, July 21, 2006, available at 2006 TNT 140-30 (LEXIS) (reprinting a July 19 letter to IRS Commissioner Mark Everson from a bipartisan group of House members calling on the IRS to halt its plans to privatize debt collection); see also NAT'L TAXPAYER ADVOCATE, I.R.S., 2006 ANNUAL REPORT TO CONGRESS 34-62 (2007), available at http://www.irs.gov/advocate/article/0,id=165806,00.html [hereinafter 2006 TAXPAYER ADVOCATE REPORT] (describing the history and performance of privatized debt collection). 
process most likely outweighs the gains to the Treasury given the huge numbers of taxpayers involved.

Another example is the decision on where to mail the notices. The Code generally requires notices be sent to the taxpayer's "last known address." The operational decision of what that means is an aggregate decision, reflected in Treasury Regulation $301.6212-2$, which is written so that human intervention is not required to verify an address for each of the 5.5 million or so accounts processed each year. ${ }^{56}$ Instead, the address contained in the IRS's main data system is deemed the last known address, even if a third party informs an IRS employee somewhere that the taxpayer has moved. The only allowed third-party information is from the U.S. Post Office National Change of Address database which IRS computers access once a week. ${ }^{57}$ Even there, the regulation provides that once a taxpayer sends in the Post Office form, the "last known address" is still the address that is in the IRS database until such time as the information transfer takes place between the agencies.

Make no mistake, the campuses are full of IRS employees. In fact, the goal of the Notice process is to get the taxpayer to call into the campus and speak with a Customer Service Representative (CSR) to resolve the account by paying it in full or by entering into one of the main collection alternatives (installment agreements, OICs, or Currently Not Collectible).$^{58}$ But just because an employee is involved does not mean that the taxpayer receives individual attention. IRS employees "in" or "at" the campuses rely heavily on the aggregate decisions reflected in the rules and instructions given to them in that capacious compendium, the Internal Revenue Manual (IRM). The IRM instructs employees how to process almost any situation they encounter and provides rules for interacting with taxpayers and interfacing with the computers. IRS employees on the campuses are much more bound by rules than are the IRS employees in the field. As is typical in bureaucracies, discretion widens as an employee moves up the hierarchy.

\section{ii. The ACS Stage}

If the taxpayer does not respond, or cannot resolve the account at the Notice stage, the account moves to the Automated Collection System (ACS) stage. ${ }^{59}$ As its name

55. See Rev. Proc. 2001-18, 2001-8 I.R.B. 708 (listing the fifteen sections of the Internal Revenue Code that require notices sent to the "last known address").

56. I use the term "accounts" or "accounts receivable." The IRS's technical term for this concept is "tax module." Generally, a "tax module" is one type of tax liability for one tax period. See, e.g., TREASURY INSPECTOR GEN. FOR TAX ADMIN., REFERENCE No. 2003-30-186, SOME AUTOMATED COLLECTION SYSTEM BuSINESS RESUlTS HAVE RECENTLY IMPROVED, BUT MORE EMPHASIS ON NONFILERS IS NEEDED 22 (2003), available at http://www.treas.gov/tigta/auditreports/2003reports/200330186fr.pdf.

57. See Treas. Reg. § 301.6212-2(b) (2001).

58. The Service Center Collection Branch is where such employees work. They handle contacts generated by both the Notice process and the ACS.

59. INTERNAL REVENUE MANUAL, supra note $35, \S 5.19 .5 .2$ ("With some exceptions, balance-due accounts and return delinquency investigations are issued to ACS at the conclusion of normal service center notice routines. The exceptions . . . are listed in Exhibit 5.19.5-9."). The decision to skip ACS and go directly to CFf is still an aggregate decision; although carried 
implies, ACS is also automated; it too operates from campuses. This is the stage where the IRS first sends out levies and files NFTLs. ${ }^{60}$ Again, I emphasize that this work is done mainly by computer systems with little human intervention. Computers decide which accounts get priority in processing. ${ }^{61}$ Computers interact with other computers to identify types and locations of taxpayer assets (such as employer name, bank accounts, etc.), and computer algorithms determine the most likely levy sources. ${ }^{62}$ The CDP Notices required by $\S 6320$ and $\S 6330$ (informing taxpayers of their rights to a Collection Due Process hearing, which I explain below) are automatically issued by computer on form letter LT11, with no human intervention. ${ }^{63}$ It is the computer system that prevents most levies until the statutory thirty days pass from the date of the CDP Notice (with an extra fifteen days built in to allow time for taxpayer CDP requests to be entered into the system). ${ }^{64}$ For some levies, an IRS employee in the Collection Branch reviews the information on a computer screen and decides how many levies to send, but even then the employee exercises little discretion on what to do and engages in little individualized decision making. ${ }^{65}$ The decisions have been made beforehand, in the aggregate. Levies exempt from CDP, such as those to states (to grab state tax

out by humans, it does not result from an individualized determination but instead from rules about how to treat classes of accounts. See id. at $\$ \S 5.1 .1 .13,5.19 .5 .3 .1$.

60. NFTL, once again, stands for "Notice of Federal Tax Lien" (emphasis added). It is not the lien. Somewhat confusingly, the IRS uses a "Notice of Levy" to perform the levy on intangible items such as bank accounts. That document is the levy. See supra text accompanying notes 41-43; see also TREASURY INSPECTOR GEN. FOR TAX ADMIN., REFERENCE No. 2004-30094, Additional EfForts ARE NeEded to Ensure TAXPa yer Rights ARE Protected WhEN MANUAL LEVIES ARE ISSUED 2-5 (2004), available at http://www.treas.gov/tigta/auditreports/2004reports/200430094fr.pdf (explaining the difference between automated and manual levies).

61. See Treasury INSPECtOR GEN. FOR TAX AdMIN., Reference No. 2004-30-165, The New Risk-Based Collection InItiative Has the Potential to INCREASE ReVENuE aNd IMPROVE FUTURE COLLECTION DESIGN ENHANCEMENTS, 1-2 (2004), available at http://www.treas.gov/tigta/auditreports/2004reports/200430165fr.pdf (describing a computer system that "use[s] predictive models to characterize accounts according to the probability of productive or unproductive closure, for routing to the most effective treatment area").

62. See INTERNAL REVENUE MANUAL, supra note $35, \$ 5.19 .4 .3 .5$ ("Levy Sources and ACS Display").

63. See id. at $\S$ 5.19.4.3.1 ("Pre-Levy Requirements").

64. Some levies are not subject to the CDP restrictions, notably those seeking to seize state income tax refunds. Such exempt levies sail right through the system with no check. See INTERNAL REVENUE MANUAL, supra note 35, § 5.19.4.3.3 ("Levy Routing and Duties"). In 2004, the Treasury Inspector General for Tax Administration (TIGTA) found the computerized systematic levy process was better than humans at complying with the thirty day CDP wait period. See TREASURY INSPECTOR GEN. FOR TAX ADMIN., supra note 61, at 2-5. By 2006, TIGTA found both error-free. See TREASURY INSPECTOR GEN. FOR TAX ADMIN., REFERENCE No. 2006-30-101, FisCAL YeAR 2006 STATUTORY REVIEW OF COMPLIANCE WITH LEGAL GUIDELINES WHEN ISSUING LEVIES 3-4 (2006), available at http://www.ustreas.gov/tigta/auditreports/2006reports/200630101fr.pdf.

65. See generally INTERNAL REVENUE MANUAL, supra note 35, § 5.19 .1 (explaining employee procedures for levies). Along these lines, note that the ACS process does not generate paper files. All data are kept in electronic format which is then picked up by the Integrated Collection System if the account is transferred to the field. Id. (giving instructions for the virtual "Desktop Integration" system). 
refunds), are completely automatic, running on weekly or monthly database matches between the IRS and the state or federal levy source. ${ }^{66}$

The point of the ACS levies is not so much to collect dollars as to get taxpayers to call into the campus and resolve the account. ${ }^{67}$ Oftentimes, taxpayers who do not respond to notices may well respond if a levy hits, say, their paycheck or goes to a third party they would prefer not know about their tax troubles. Although $\S 7602$ authorizes the IRS to gather information by using summonses, the process would be far more efficient by whacking the taxpayer over the head hard enough to prompt contact in order to resolve the account.

The raw numbers give one a feel for the bulk nature of the ACS collection process. In fiscal year 1997, the last full year before Congress enacted the CDP requirements, ACS sent out over 2.9 million levies, which brought in $\$ 2.296$ billion. ${ }^{68}$ By fiscal year 2000 , due in large part to the impact of the CDP requirements, ACS sent out only 144,000 levies, but still collected almost $\$ 1.159$ billion. ${ }^{69}$ That is, ACS collected over fifty percent of the dollars using only five percent of the levies. By fiscal year 2005 , ACS levies almost returned to their former levels of 2.535 million, bringing in $\$ 1.9$ billion. ${ }^{70}$

These numbers also suggest something else. Most levies shooting out of ACS are blanks. They don't hit anything. That does not mean, however, that they are useless. What they do accomplish is to help taxpayers realize the need to address the tax delinquency in a way that a simple letter cannot.

\section{iii. The Field Stage}

Accounts not resolved through the Notice or ACS processes are assigned by computer to Revenue Officers (RO) in the field (the CFf), using the Integrated Collection System (ICS), another computer system. Again, since each RO can only handle so many accounts, accounts are assigned priority using a pre-determined algorithm, once again representing an aggregate decision. Therefore, only some get assigned while the others wait their turn in what is called "the queue." Some wait so

66. See I.R.C. $\S 6330(f)(2000)$; see also INTERNAL REVENUE MANUAL, supra note 35 , 5.19.9 ("Automated Levy Programs").

67. There is a robust debate within the IRS on whether this use of ACS is the best collection policy. The National Taxpayer Advocate has tirelessly advocated for more use of active IRS employee outreach at the ACS stage rather than passive dependence on taxpayers calling in to resolve their accounts. See, e.g., 2006 TAXPAYER ADVOCATE REPORT, supra note 54, at 62-82. The merits of that debate are beyond the scope of this Article, and the IRS management has indicated that it has no intent to modify ACS operations. Id. at 75-77. In fact, the IRS is creating even more bulk processing algorithms to "use internal and external data on taxpayer characteristics to better match taxpayers to the treatment stream that will most likely result in meaningful contact and timely resolution of the case." Id. at 76. Accordingly, this Article focuses on how ACS is used now and in the foreseeable future and not on how it might be used in a more perfect world.

68. 2005 TRENDS REPORT, supra note 54, at 25, 29.

69. Id.

70. Id. 
long that they get timed out and written off. ${ }^{71}$ Here, although ROs use the ICS to generate levies and NFTLs, they also generate them manually as they engage in the more traditional methods of searching for delinquent taxpayers and their assets through old-fashioned legwork. And it is only here, in the field, the final collection stage, that an IRS employee works each case individually in the stereotypical way most people think of when they think of tax collection: a face-to-face encounter with a Revenue Officer.

\section{Of Can't-Pays and Won't-Pays}

The conceptual context of collection is classification. Taxpayers must be sorted into the correct "box" for appropriate treatment: "can't-pays" or "won't-pays." Operationally, classification decisions are made any time a taxpayer seeks one of the collection alternatives. That can happen at any stage - either in response to a notice, a levy, or a RO banging on the door. The IRS decision about the collection alternative is what classifies the taxpayer as a won't-pay or can't-pay. Thus, the operational rules for deciding who is entitled to an installment payment, who is entitled to compromise their liability, or who should be designated as "currently not collectible" are all rules about who will be determined to be a can't-pay at a particular point in time. For example, when a taxpayer seeks an Offer In Compromise (OIC), the taxpayer has to submit over fifty pages of forms in the OIC Form 656 application package. ${ }^{72}$ The forms ask for detailed personal financial information, and the IRS employee processing the forms uses the information to verify the taxpayer's claimed lack of assets through third parties. $^{73}$

Not all classification decisions are individualized. Some are aggregate decisions. For example, to evaluate an OIC, an IRS employee must determine the taxpayer's ability to pay, which requires a decision about what living expenses to allow as necessary. ${ }^{74}$ The IRS has developed national and local tables of allowable expenses, and while the regulations provide that a taxpayer's allowable living expenses should be an individualized determination, the IRM directs employees to use the tables in some cases as a cap, and in other cases as a presumption. ${ }^{75}$ Congress also makes aggregate

71. See id. at 26 (showing that 788,083 delinquent accounts were removed from the queue inventory in fiscal year 2005).

72. U.S. GOV'T ACCOUNTABILITY OFFICE, GAO-06-525, IRS OFFERS IN COMPROMISE: Performance Has BeEn MIXed; Better Management Information and Simplification COULD IMPROVE THE PROGRAM 8 (2006), available at http://www.gao.gov/new.items/d06525.pdf [hereinafter GAO OIC STUDY].

73. See generally id. at 8-11 (describing the OIC process).

74. INTERNAL REVENUE MANUAL, supra note $35, \S 5.8 .8$.

75. See generally INTERNAL REVENUE MANUAL, supra note $35, \S 5.19 .1 .6$ ("Analyze Taxpayer's Ability to Pay"). The National Taxpayer Advocate discusses this point in detail in her 2005 Annual Report. See 1 NAT'L TAXPAYER ADVOCATE, I.R.S., 2005 ANNUAL REPORT TO CONGRESS (2005), 271-81 available at http://www.irs.gov/advocate/article/0,id=152735,00.html [hereinafter 2005 TAXPAYER ADVOCATE REPORT]. As an empirical matter, how often (if at all) IRS employees deviate from the national and local tables is not clear-the National Taxpayer Advocate says they rarely do, and the IRS response disagrees. See id. at 281-86. What is clear, however, is that the tax 
decisions. Section 6159(c) requires the IRS to accept installment agreements from all taxpayers whose liability is less than $\$ 10,000 .^{76}$

Procedurally, all taxpayers start out in the won't-pay box. This is because the IRS does not know why a taxpayer has not paid the tax. The taxpayer knows. And the aggregate decision is to keep taxpayers in the won't-pay box until an individualized decision is made otherwise. That is why I emphasize that the collection process is not just about collecting money, but is also in large part about collecting information necessary to make the classification. Taxpayers remain under the legal obligation to pay the assessed amount unless and until they convince an IRS employee at some stage that they truly cannot pay, within the policy's guidance as to what that means. Until they do, the IRS pursues their assets. The won't pay presumption is proper not just because citizens have the legal duty to report their financial transactions to the government and to pay the appropriate tax, but also because it places the information burden on the party who has best access to the relevant information. ${ }^{77}$

Proper classification is a dynamic process. Taxpayers may make multiple attempts to seek classification as a can't-pay. For example, in fiscal year 2005, almost forty percent of taxpayer OIC submissions were repeat attempts. ${ }^{78}$ Taxpayers who are judged won't-pays at one stage might later be judged can't-pays as their facts and circumstances change or as they are reviewed by different decision makers or subjected to different rules. I cannot overstate the dynamic nature of the classification decision. Taxpayers have multiple opportunities to present information to various components of the IRS. Since each collection stage involves different IRS employees, this means that even with the same information, different decision makers may come to different conclusions about a taxpayer. For example, while one component of the IRS might reject a taxpayer's OIC because the review process leads to a prediction that the taxpayer can pay more than is offered, that prediction may prove to be false and nothing further is ever collected from the taxpayer. ${ }^{79}$ Similarly, as time goes on, a taxpayer's circumstance changes, which can change his or her classification in either direction. For example, in a recent study, the GAO noted that between 1998 and 2003, about fifteen percent of taxpayer accounts where an OIC was rejected was later

practitioner community widely believes that the aggregate decision that the tables represent is rarely modified on an individual basis. Id.

76. The IRS has operationalized this requirement. See INTERNAL REVENUE MANUAL, supra note $35, \S 5.14 .5 .3$. As is usual, practical bulk processing reasons have led the IRS to go beyond the statutory requirements in that it will accept an installment agreement even if the taxpayer can fully pay the tax immediately. Id. This saves the IRS employees from having to make an additional determination of the taxpayer's ability to pay immediately.

77. The National Taxpayer Advocate, for one, suggests that a better tax collection policy would put all taxpayers in the can't-pay box as a start, for the common sense reason that most taxpayers, in fact, want to pay their taxes and only a small minority seeks to avoid its civic responsibilities. See 2006 TAXPAYER ADVOCATE REPORT, supra note 54, at 74-75. The operational difficulty with this approach, however, is the information asymmetry between the individual taxpayer and the IRS. See generally Camp, supra note 2, at 5-17.

78. See GAO OIC STUDY, supra note 72, at 13 fig.2.

79. See 2004 TAXPAYER ADVOCATE REPORT, supra note 52, at 311. The IRS collected nothing from thirty-seven percent of those OICs that were rejected as too low an offer or for lack of information to make a reasonable collection potential classification. Id. The National Taxpayer Advocate did not break out what part of the thirty-seven percent was due to what cause. 
deemed Currently Not Collectible. ${ }^{80}$ And the Currently Not Collectible decision itself is often made for taxpayers who have little current liquidity but large equities in their primary residences and future income from retirement accounts. ${ }^{81}$

One can conceptualize all collection activity as classification. A look at the overall statistics on IRS inventory management illustrates the point. The Treasury Inspector General for Tax Administration (TIGTA) Trends in Compliance Activities report for fiscal year 2005 (issued March 2006) says that over 5.373 million $^{82}$ delinquent collection accounts were closed at some stage during the collection process. Of that number, 1.424 million were closed by full payment, with 186,000 during the Notice stage, 848,000 during the ACS stage, and 391,000 during the CFf stage. ${ }^{83}$ By definition, these accounts represent the won't-pays because they eventually proved to have the resources to fully pay the amount owed. Another 788,000 were simply written off the books while waiting in the queue to be worked in the field, generally because of the account's small amount, the taxpayer's increasing age, and lack of taxpayer information on the account. ${ }^{84}$ That leaves 3.161 million accounts closed by one of the collection alternatives. ${ }^{85}$ Those are taxpayers who, for whatever reason, were adjudged by the agency, at some point in time, to be can't-pays. Unfortunately, neither the GAO nor TIGTA have produced any statistics showing how many accounts shake out as can't-pays during each of the stages, but it is certain that there is some distribution among the three stages just as there is a distribution of liabilities fully paid. ${ }^{86}$

Proper classification is difficult, even with enough information. A moment's reflection will suffice to realize that the definitions of won't-pay and can't-pay are highly operational and contingent on tax administration policy. While simple at the extremes, classification is difficult in the majority of cases. At one extreme are those in tax protestor communities, whether religious or political. They have the money but refuse to acknowledge the government's right to it, for reasons either godly or godawful. At the other extreme are the true turnips who have nothing now and never will. In between are the vast majority of taxpayers who do not have quite enough assets right now to fully pay all their tax and nontax obligations. Their cry of can't-pay pain merely means they prefer to pay competing creditors or that competing creditors presented a more compelling reason to get paid first. Think Tony Soprano. Determining whether that preference qualifies for can't-pay treatment is central to the

80. See GAO OIC STUDY, supra note 72, at 25 tbl.7.

81. See INTERNAL REVENUE MANUAL, supra note $35, \S 5.16 .1 .6$ ("Mandatory Follow-Up").

82. The sum of the three values within the Trends in Compliance Activities bar chart is 5.373 million.

83. 2005 TRENDS REPORT, supra note 54 , at 28 tbl.15.

84. Id. at 26 tbl.11.

85. The subtraction of the won't-pays' 1.424 million accounts paid in full and the 788,000 accounts written off the books from 5.373 million is 3.161 million.

86. It is also unfortunate that the statistics tend to be reported as "accounts" rather than "taxpayers." A taxpayer may owe multiple tax liabilities (either different kinds of taxes for the same tax period, most usually employment and income, or the same kind of tax for multiple tax periods). So reporting by "accounts" obscures just how many taxpayers we are talking about. This is one of the flaws of CDP review discussed below. 
task of knowing whether to accept or reject the installment agreement or the OIC or to shunt the taxpayer into the Currently Not Collectible bin.

Proper classification thus depends in large part on policy. Which competing creditors should the government yield to: landlords, ex-spouses, or private lenders? How many assets should a taxpayer be allowed to keep to meet competing obligations? When is a taxpayer's situation so precarious that his or her tax obligations should be modified or forgiven? These are all matters of policy. Some policies are set by Congress. For example, $\S 6334$ lists assets exempt from levy-such as that $\$ 3,125$ worth of books and tools mentioned earlier-and can be viewed as reflecting a congressional decision to allow taxpayers to prefer certain competing obligations over their tax obligations. Section 6334 also exempts a minimum portion of wage income, as well as such income necessary to make child support payments. ${ }^{87}$

The Treasury and the IRS make most policy calls on who goes into the can't-pay box. In fact, Congress will sometimes explicitly decline to make a policy call in a statute in order to give the agency operational flexibility. For example, in the massive Internal Revenue Service Restructuring and Reform Act of 1998 ("RRA 98"), Congress wanted the IRS to expand the definition of can't-pays used to determine who should get their tax liabilities compromised. ${ }^{88}$ But, it did not express the idea in the resultant statute. ${ }^{89}$ Instead, Congress "expressed a mood." 90 The Conference Committee report instructs the IRS to create a new category of persons eligible to compromise their liabilities: those whose classification as can't-pay (through the act of compromising the liability) would "promote effective tax administration" because of "factors such as equity, hardship, and public policy.""1 In other words, rather than draw a bright line, Congress decided to "draw the right line" between can't-pays and won'tpays. It left the policy decision to the IRS and Treasury. ${ }^{92}$

The IRS has every incentive to make the right decision. Chronic misclassification has the potential to undermine voluntary tax compliance, the foundation of our system. On the one hand, if the definition of can't-pay is too narrow, then the IRS pursues taxpayers who truly cannot pay. Not only does that waste resources but it also makes

87. See I.R.C. $\S 6334$ (2000).

88. See Internal Revenue Service Restructuring and Reform Act of 1998, Pub. L. No. 105$206, \S 3462,112$ Stat. $685,764-66$ (1998).

89. See I.R.C. \& 7122 (2000).

90. Universal Camera Corp. v. NLRB, 340 U.S. 474, 487 (1951).

91. H.R. REP. No. 105-599, at 289 (1998). The idea ended up in the Conference Report, and not in the statute, thanks in part to the negotiating skills of the lead Treasury Department representative, Chris Rizek. It is beyond the scope of this article to discuss how this introduction of equity norms into tax administration is at odds with the traditional "turn-square-corners" approach of administrative law in general and tax administration in particular. Suffice to say that a similar shift occurs in many other "equitable" provisions such as those covering Taxpayer Assistance Orders and Spousal Relief. Some of the provisions work well, others do not. But all of them undercut the traditional idea of a "true" tax liability in favor of a more flexible approach where-like much else in current postmodern life where the contingency of truth is, ironically, itself an accepted truth-tax liabilities are treated more as simply another item up for negotiation and less as a civic responsibility. One might want to debate the wisdom of that move; no one in Congress ever did.

92. See Treas. Reg. $\S 301.7122-1$ (b)(3) (2002). But see GAOOIC STUDY, supra note 72, at 35-38 (critiquing implementation of the "effective tax administration" concept). 
the IRS look hard and mean, thereby undermining confidence in government and leaving the citizenry-and ultimately democracy-vulnerable to charlatans and demagogues. On the other hand, if the definition is too broad, the IRS looks like a chump, and those who have paid their taxes wonder why the hammer never falls on similarly situated taxpayers who shirked their responsibility. Error in either direction weakens voluntary compliance, which depends in no small measure on perception. ${ }^{93}$

By definition, misclassification results in mistreatment. To treat people "right," one must first make a judgment about what kind of people they are. The allegations in the sensationalist congressional hearings into IRS "abuse" in 1997 and 1998 were all about mistreatment and, hence, about misclassification. ${ }^{94}$ The IRS was allegedly treating taxpayers wrongly because it was either trying to collect taxes not really owed or else it was brutishly depriving taxpayers of the very assets they needed to survive. In other words, it was treating can't-pays as won't-pays.

\section{THE PROMISE OF CDP}

"I think we are all concerned about stories that we hear every day from our constituents about how they are being abused.... I have followed enough cases in my State through the whole process to reach the conclusion that ... there are people who use the power to intimidate that obviously working for the IRS gives the ability to do. ${ }^{\prime \prime 95}$

Recall the power of an assessment. Until 1998, once the IRS assessed a tax, the Anti-Injunction Act made it well nigh impossible for taxpayers to complain in court about any decisions-liability or collection-until after the liability had been fully paid. ${ }^{96}$ The existence of an assessment allowed the IRS to call the collection tune, and full payment was the price to stop the music and obtain judicial review.

In 1997 and 1998, Senators William Roth and Charles Grassley orchestrated a series of hearings to highlight what they perceived as problems in tax collections. ${ }^{97}$ The hearings were full of collection horror stories. Witness after witness complained that IRS employees were taking unwarranted enforcement actions for illegitimate reasons. The focus of the hearings was in large part on how, due to perverse incentives, individual IRS employees took overly aggressive and inappropriate enforcement action. The perception of the lawmakers was that the IRS had too many bad apples and

93. See generally Leandra Lederman, The Interplay Between Norms and Enforcement in Tax Compliance, 64 OHIO ST. L.J. 1453 (2003).

94. For an extensive description, see Camp, supra note 2, at 78-91.

95. Practices and Procedures of the Internal Revenue Service: Hearing Before the S. Comm. on Finance, 105th Cong. 16 (1997) (opening statement of Sen. Phil Gramm).

96. Courts were very reluctant to find exceptions outside those listed in the statute itself. See Enochs v. Williams Packing \& Navigation Co., 370 U.S. 1, 5-8 (1962).

97. The three most important sets of hearings were: (1) IRS Oversight: Hearing Before the S. Comm. on Finance, 105th Cong. (1998) [hereinafter Hearing on IRS Oversight]; (2) IRS Restructuring: Hearing on H.R. 2676 Before S. Comm. on Finance, 105th Cong. (1998) [hereinafter Hearing on IRS Restructuring]; and (3) Practices and Procedures of the Internal Revenue Service: Hearing Before the S. Comm. on Finance, 105th Cong. (1997) [hereinafter Hearing on Practices and Procedures]. 
needed oversight. The opening statements of the various committee members demonstrated this understandable focus on people abusing others. ${ }^{98}$

The hearings did an excellent job of creating distrust towards the tax bureaucracy. ${ }^{99}$ The clamor for adversarial process was loud: "See, the problem that you have is that you have got an internal conflict of interest within the IRS. They are their own judge and jury over people's lives. Let us remove that. This will cure the 'Ivory Soap's' worth of taxpayer abuse." 100 Senator Gramm summed up the prevailing view among the lawmakers: "[T]his agency has too much unchecked power. An agency in a free society should never have the ability to investigate, evaluate, and basically prosecute, all wrapped up into one ... With the Internal Revenue Service, you have no external checks, and I think, basically, that is the problem."101

In response to the dust and noise, Congress created CDP, an adversarial process, to be Senator Gramm's "external check" and enacted it as part of the Internal Revenue Service Restructuring and Reform Act of 1998 ("RRA 98"). ${ }^{102}$

\section{A. As Proposed: The Senate Version}

The promise of CDP was to correct IRS misclassifications ultimately through the adversarial process in court. ${ }^{103}$ The proposal, made by the Senate Finance Committee and adopted by the full Senate (there was no comparable version in the House bill), was a very strong move towards judicial review. The Senate proposal would have required the IRS to give taxpayers thirty days notice before each levy or NFTL. During that time, taxpayers could ask the IRS for an administrative hearing, and if they did not like the result, they could ask for judicial review of each particular collection decision. Further, the Senate proposal would have allowed taxpayers not only to challenge the proposed collection decision at the hearing but also to raise any issue, including a challenge to the liability determination reflected by the assessment. Taxpayers would then have thirty days to appeal to a court from an adverse decision. Meanwhile, the

98. See Hearing on IRS Oversight, supra note 97, at 6 (statement of Sen. Charles E. Grassley).

This week we will hear testimony about horrors caused by IRS agents .... This does not mean that all IRS employees are bad .... At this moment, these hearings are about these people and the horrendous acts that have taken place. But in the bigger picture they are proof that more oversight and more diligent oversight is vital.

Id.

99. For a fuller analysis, see Camp, supra note 2, at 80-87. For the purposes of this paper, I highlight only how both the proposed CDP statutes and the enacted CDP statutes rest on an assumption of individualized abuse.

100. Hearing on Practices and Procedures, supra note 97, at 58 (testimony of attorney Robert Schriebman, Adjunct Professor of Tax Practice \& Procedure, University of Southern California Graduate School of Accounting).

101. Hearing on IRS Oversight, supra note 97, at 210-11 (statement of Sen. Phil Gramm).

102. See Internal Revenue Service Restructuring and Reform Act of 1998, Pub. L. No. 105 206, §§ 4001-02, 112 Stat. 685, 783-84 (1998).

103. For the following description about the Senate proposal, see S. REP. No. 105-174, at 67-68 (1998); see also Montgomery v. Comm'r, 122 T.C. 1, 13-17 (2004) (Laro, J. \& Gale, J., concurring). See generally Camp, supra note 2, at 119-28. 
IRS would be barred from taking the proposed action. While the IRS could propose another levy or another NFTL, the taxpayer would then be entitled to a separate "kitchen sink" hearing to raise any issue whether related to liability or collection, and then take a separate court appeal. While there were issue preclusion rules, there were no claim preclusion rules. If the taxpayer could think up new arguments (or just string them out), then the taxpayer could present them at the next court review.

The Senate proposal was a logical response to the "problem" of individual IRS employees being out of control or being given perverse incentives, like quotas, to do their work. By providing for judicial review of each levy or NFTL action, the assumption here was that the IRS made individualized decisions about all liens and levies. The Senate taxwriters operated from a vision of tax administration as individualized decision making.

The Senate proposal was also a logical response to the "problem" of collecting tax liabilities not truly owed by taxpayers. By allowing court review of the liability decision represented by the assessment, the proposal would have eviscerated the historic pay-first rule and the Anti-Injunction Act and reduced the legal effect of the assessment to almost a nullity. The taxwriters did not appear to understand how the deficiency procedures interacted with the Anti-Injunction Act or how most accounts receivable were based on self-reported liabilities.

Even taken on its own terms, the Senate proposal had some problems. Pre-notice for each NFTL would allow taxpayers to extract equity from their real estate by obtaining a secured loan (recall that the bank would become one of the "four horsemen" protected from the tax lien ${ }^{104}$ ). Pre-notice of each levy would allow taxpayers to switch banks and re-title assets. The thirty-day period to contest a proposed NFTL or levy would essentially become a thirty-day period to hide, move, or encumber assets. Further, court review for each levy would result in huge delays as taxpayers took advantage of multiple bites at the judicial review apple. Although these concerns carried no weight in the Senate, the Treasury did have more success with the Conference Committee, which revised the Senate's proposal into the legislation eventually enacted. ${ }^{105}$

\section{B. As Enacted: Conference Committee Modifications}

The Conference Committee weakened the Senate's strong move to judicial review in two ways. First, rather than allowing taxpayers to contest each and every collection action and the merits of liabilities in all situations, the Conference Committee revised the language to allow for only two CDP hearings: one after the first NFTL and one before the first levy. ${ }^{106}$ This meant that the IRS would not have to defend each proposed levy as a separate individualized decision. Moreover, it would not have to identify any particular asset it proposed to levy. While that solved the Service's problem of taxpayers moving assets, it created a significant problem for taxpayers: how to argue against an abstract decision to levy. Instead of protesting a particularized

104. See supra text accompanying note 41 .

105. For a public example of the administration's lobbying, see $C B O$ Revenue Estimates of IRS Bill Reform, TAX NOTES TODAY, May 6, 1998, available at 98 TNT 87-17 (LEXIS). That was just the tip of the lobbying iceberg.

106. H.R. REP. No. 105-599, at 263-67. (1998) (Conf. Rep.). 
decision to levy a particular asset-a car, for example - a taxpayer was now forced to protest the aggregate decision to levy any item of property.

Second, the Conference Committee limited taxpayers' ability to contest liability decisions. ${ }^{107}$ Taxpayers could now only protest the liability if they did not actually receive a notice of deficiency or if they "did not otherwise have an opportunity to dispute the liability." 108 The Conference Committee Report explained the statutory language: "[T] he validity of the tax liability can be challenged only if the taxpayer did not actually receive the statutory notice of deficiency or has not otherwise had an opportunity to dispute the liability."109 The "not otherwise have an opportunity" language was intended to prevent taxpayers under audit from ducking their chance for Tax Court pre-payment review by agreeing to the examination report prior to the issuance of a Notice of Deficiency, consenting to immediate assessment on a Form 870 , and then later claiming they had no entitlement to Tax Court review because there had been no Notice of Deficiency. ${ }^{110}$

\section{As Implemented: How CDP Works}

CDP applies to levy actions and to NFTLs. The CDP provisions regarding levies are in $\S 6330$. The CDP provisions for NFTLs are in $\S 6320$, but because that statute basically piggybacks on $\S 6330$, the following discussion cites generally only to $\S$ 6330. ${ }^{11}$ CDP has four main components: (1) notice; (2) administrative hearing; (3) judicial review; and (4) post-determination review. I will discuss each in turn, showing how the IRS has adapted the CDP requirements to its bulk processing collection environment.

\section{CDP Notice}

The IRS must give taxpayers up to two notices of their right to a CDP hearing for each separate tax liability sought to be collected. Section 6330(a)(1) requires a CDP notice before the first time the IRS attempts to exercise its levy powers. Section 6320(a)(2) requires notice within five days after the IRS files any NFTL and requires a CDP notice after the first NFTL. Both statutes give taxpayers thirty days from the date the notice is sent, not received, to request an administrative hearing (the CDP hearing). ${ }^{112}$ While the statutes allow the CDP notice to be delivered to the taxpayer in person or left at the taxpayer's house, the most important mode of service is "by

107. See id.

108. I.R.C. $\$ 6330(\mathrm{c})(2)(B)(2000)$.

109. H.R. REP. No. 105-599, at 265 (1998) (Conf. Rep.) (emphasis added).

110. See generally Pomerantz v. Comm'r, 90 T.C.M. (CCH) 628,629 (2005) (Involving a taxpayer that "did not otherwise have an opportunity to dispute such tax liability" when properly sent a Notice of Deficiency but the taxpayer's attorney chose to waive taxpayer's rights to contest the deficiency in Tax Court by signing a Form 4549). For one startling example of the taxwriter's misunderstanding of the deficiency process, see Camp, supra note 2, at 114-17.

111. For the corresponding regulations, see Treas. Reg. $\S \S 301.6320-1,301.6330-1$ (both as amended in 2006).

112. See $\S 6320(a)(3)(B), 6330(a)(3)(B)(2000)$. 
certified or registered mail, return receipt requested, to [the taxpayer's] last known address."113

As implemented, the IRS sends approximately eighty-four percent of all CDP notices automatically out of ACS. ${ }^{114}$ The computers automatically spit out form letter LT11 with no human intervention. ${ }^{115}$ The unfortunate requirement that the notices be sent "return receipt requested" invariably fools a certain percentage of taxpayers into thinking that they must sign for the notice to make it valid. ${ }^{116}$ They deliberately avoid receipt and gleefully think they have beaten the system. Sadly, the information that tells them they have not comes in the very package they refused. Even taxpayers who take delivery can never, by definition, get thirty days from the sent date to respond.

The statute requires a substantial amount of information to be included with the CDP notice, including what tax liability is being collected, how much is owed on it, what the proposed action is, a "brief statement" explaining the entire law of seizures and sales (including redemption rights), how the taxpayer can appeal, and what collection alternatives the taxpayer can propose. ${ }^{117}$ As implemented, the IRS not only sends the one-page notice (usually in the form of ACS pattern letter LT11) and the two-page Form 12153 (Request for a Collection Due Process Hearing), but it also includes two IRS Publications, the twelve-page Pub. 594 (Understanding the Collection Process) and the four-page Pub. 1660 (Collection Appeal Rights). ${ }^{18}$ Whenever possible, the IRS sends out both required CDP notices at once, so as to consolidate the potential two hearings into one. ${ }^{119}$

113. $§ 6330(a)(2)(C)$.

114. For fiscal year 2004, the only year for which statistics are available, ninety-four percent of levy CDP notices and eighty-four percent of all CDP notices issued from ACS. See 2005 TAXPAYER ADVOCATE REPORT, supra note 75, at 459.

115. See Internal Revenue Manual, supra note 35 , $\S 5.18 .4 .3 .4$ ("Pre-Levy Requirements"). Until January 19, 1999, these notices were sent during the Notice stage, but they are now sent during the ACS stage. This theoretically allows IRS employees to call taxpayers first, although resource constraints since 1998 have prevented such proactive measures in practice. See 2004 TAXPAYER ADVOCATE REPORT, supra note 52, at 232-43 (critiquing the failure of telephone outreach).

116. The phenomenon was documented in an internal IRS study of Notices of Deficiency, which are sent certified or registered and without a return receipt. No other statute requires return receipts on such high volume notices. The National Taxpayer Advocate has recommended dropping this requirement. 2005 TAXPAYER ADVOCATE REPORT, supra note 75, at 462. It was quite a trick for the IRS to build machines that could attach the little green Post Office return receipt cards without using human labor.

117. See $\S 6330(\mathrm{a})(3)(\mathrm{C})$.

118. See $\S 6320(\mathrm{~b})(4)$; Treas. Reg. $\S 301.6320-1$ (d) (as amended in 2006). Though the statutes do not directly discuss the implementation process, these forms are used commonly in practice.

119. See $\S 6320(\mathrm{~b})(4)$; Treas. Reg. $\S 301.6320-1$ (d)(2) (as amended in 2006) (questions two and three and the corresponding answers). 


\section{CDP Hearings and Equivalent Hearings}

"CDP hearings" are for taxpayers who make timely, written requests in response to the CDP notices. ${ }^{120}$ They get the administrative hearing provided for by statute. ${ }^{121}$ The hearing must be conducted by an "impartial officer" from the IRS Office of Appeals, an independent function operating within the IRS bureaucracy. ${ }^{122}$ At the hearing, $\S$ 6330(c) directs the hearing officer-called the Settlement Officer ("SO"), usually an experienced former collection field employee - to do three tasks: (1) verify the legality of the liability and proposed action; (2) consider any appropriate taxpayer argument; and (3) "balance the need for the efficient collection of taxes with the legitimate concern of the person that any collection action be no more intrusive than necessary." $" 123$

To accomplish these tasks, CDP requests are assigned to a SO who then sends the taxpayer a letter inviting direct contact and asking for the information the SO needs to perform the three tasks. ${ }^{124}$ The SO then issues a decision document called the Notice of Determination (note the parallel nomenclature to "Notice of Deficiency"), which is the taxpayer's "ticket" to judicial review.

"Equivalent Hearings" are for taxpayers who fail to make timely, written requests for a CDP hearing. The IRS bound itself in its regulations to give taxpayers the same process as given in CDP hearings and requires SOs to perform the same three tasks: verify the liability, consider issues raised by the taxpayer, and perform the same

120. Although the statute does not require the request be in writing, the IRS put that in the regulation. See Treas. Reg. $\S 301.6330-1$ (a) (as amended in 2006).

121. However, $\$ 6330(\mathrm{~g})$ does allow the IRS to disregard "any portion of a request for a hearing" that meets the definition of "specified frivolous submission" per $\S 6702(\mathrm{~b})(2)(\mathrm{A})$. I.R.C. $\$ \S 6330(\mathrm{~g}), 6702(\mathrm{~b})(2)(\mathrm{A})(2000)$. Congress added this provision in an attempt to cut down on the volume of won't-pays who were attempting to use CDP proceedings to delay collection. See Tax Relief and Health Care Act of 2006, Pub. L. No. 109-432, §6702, 120 Stat. $2922,2960-62$. The provision requires the IRS to publish a list of positions it deems frivolous. The IRS published the first list in Notice 2007-30. See I.R.S. Notice 2007-30, 2007-1 C.B. 883. Thus, this provision came into force after the period examined within this Article.

122. See I.R.C. $\$ 6330$ (b) (2000) (requiring that " $\mathrm{t}]$ he hearing under this subsection shall be conducted by an officer or employee who has had no prior involvement with respect to the unpaid tax ...."). Although the statute is silent on the Office of Appeals and its role within the IRS, this statute refers to the Office of Appeals indirectly because the statute is for the appealing party, which works directly with the Office of Appeals. See INTERNAL REVENUE MANUAL, supra note $35, \S 1.17$.

123. Section 6330 (c) requires the appeals employee to "obtain verification . . . that the requirements of any applicable law or administrative procedure have been met" and allows the taxpayer to raise "any relevant issue," either about the proposed collection action (levy or NFTL), or about the underlying tax liability. But a taxpayer may only challenge the underlying liability the taxpayer shows that he or she "did not receive any statutory notice of deficiency for such tax liability or did not otherwise have an opportunity to dispute such tax liability."

124. Cf. Carlton M. Smith, Does the Failure to Appoint Collection Due Process Hearing Officers Violate the Constitution's Appointments Clause? 8 (Cardozo Legal Studies, Research Paper No. 245, 2008) (describing system used to issue notices of determination). 
balancing analysis. ${ }^{125}$ The critical difference is that the taxpayer is not entitled to judicial review of Equivalent Hearings. This difference is reflected in the decision document's title. A CDP hearing results in a Notice of Determination, which is another "ticket to the Tax Court" like a Notice of Deficiency. But an equivalent hearing results in a document titled "Decision Letter." It is a ticket to nowhere.

In implementing the statute, the IRS has transformed the meaning of "hearing" into something completely different from what was contemplated by Congress. Congress assumed that the "hearing" would be a discrete event. ${ }^{126}$ But the IRS has stretched that concept to a degree that obliterates the adversarial concept of a "hearing" as a single point in time where all the parties come together to hash out all the issues at once. In its place, the IRS has created an inquisitorial hearing process. This transformation can be seen in multiple ways.

First, CDP hearings need not be conducted in person and need not be a single event, but may instead be a series of telephonic or written correspondence taking place over time. ${ }^{127}$ Even if a taxpayer requests an in-person hearing, the Appeals Officer can refuse the request if, in his or her judgment, there is nothing to have a hearing about. ${ }^{128}$ There is no requirement that the SO tell the taxpayer what the hearing will consist

125. See Treas. Reg. § 301.6330-1(i)(2), Q \& A 12(2006) ("[The Office of] Appeals will consider the same issues that it would have considered at a CDP hearing on the same matter."). See generally I.R.S. Chief Counsel Notice CC-2003-016 (May 23, 2003), available at http://www.unclefed.com/ForTaxProfs/irs-cedm/2003/cc-2003-016.pdf (addressing Collection Due Process cases). The regulation follows up on the strong hint made by Congress in the Conference Report. See H.R. REP. No. 105-599, at 266 (1998) ("The Secretary must provide an equivalent hearing to the pre-levy hearing if later requested by the taxpayer.").

126. This is seen in language of the Conference Report, which refers to the "date of the hearing," "the scheduled hearing," and "at the time of the pre-levy hearing." H.R. REP. No. 105599 , at 266.

127. See Treas. Reg. $\S 301.6630-1$ (d)(2) (as amended in 2006); Loofbourrow v. Comm'r, 208 F. Supp. 2d 698, 707 (S.D. Tex. 2002) (stating that a series of letters between taxpayer and the Office of Appeals constituted a sufficient "hearing").

128. The policy is spelled out in a 2003 I.R.S. memorandum. See I.R.S. Chief Counsel Notice CC-2003-031 (Sept. 1 1, 2003), available at http://www.unclefed.com/ForTaxProfs/irs$\mathrm{ccdm} / 2003 / \mathrm{cc}-2003-031$.pdf. The policy is used with non-cooperative taxpayers who tend to be tax protestors. See id. This practice has been approved by the Tax Court. See Katz v. Comm'r, 115 T.C. 329 (2000). Many federal district courts have also approved the practice. Cf. Frese v. United States, No. 05-1741, 2006 WL 231895, at *7 (D.N.J. Jan. 30, 2006) (holding that Appeals Officer's refusal to hold a face-to-face hearing until taxpayer submitted a later year's tax return and providing specific information relating to his financial status was not abuse of discretion). But see Cavanaugh v. United States, No. 03-250, 2004 WL 880442, at *6 (D.N.J. Mar. 23, 2004) (holding that a SO's decision to deny a request for a face-to-face hearing and instead proceed by telephone was an abuse of discretion). 
of. ${ }^{129}$ It is no wonder that hearings can sometimes be so informal that a taxpayer may not understand that one took place until receiving the Notice of Determination. ${ }^{130}$

Second, when a taxpayer requests a CDP hearing, the Internal Revenue Manual (IRM) instructs the IRS collection employee responsible for the case to continue working on it for forty-five days after the CDP request or, with management approval, up to ninety days. ${ }^{131}$ The collection employee is instructed to offer the taxpayer "Fast Track Mediation," an internal program designed to give taxpayers the ability to resolve their accounts by negotiating through a third-party mediator. ${ }^{132}$

Third, there is no adversarial party. Once the collection employee transmits the file to the SO, further contact is restricted to requests by the Office of Appeals for further information. ${ }^{133}$ The collection employee does not participate in the "hearing" but is restricted to writing a "dissent" if the SO accepts a collection alternative. The "dissent" becomes part of the package that is elevated within the IRS's review chain. ${ }^{134}$ Thus, the Appeals SO now works the case, involving other functions as needed. For example, if the taxpayer makes an Offer In Compromise and submits a processable Offer, the IRM provides that:

Appeals will generally work the offer investigation internally using electronic research sources and taxpayer documentation, particularly when the offer is not complex or does not require any field verification. If complex financial analysis issues surface, either regarding particular asset(s) or the offer as a whole, Appeals may send an Appeals Referral Investigation (ARI) to Collection for assistance. Appeals will retain jurisdiction of the offer in these instances. ${ }^{135}$

The final way in which the IRS has transformed the CDP process into another collection stage is by presuming that the "hearing" begins with the issuance of the initial contact letter by the Appeals SO and ends with the issuance of the Notice of Determination (for CDP hearings) or the Decision Letter (for Equivalent Hearings). ${ }^{136}$ Likewise, the Office of Chief Counsel has instructed its attorneys that the "administrative record" includes everything in the SO's file, both written and electronic. $^{137}$

129. AllGlass Sys., Inc. v. Comm'r, 330 F. Supp. 2d 540, 545 (E.D. Pa. 2004) ("[T] here is no requirement that a $C D P$ hearing be specifically designated as such by the conducting officer so long as the taxpayers and IRS officers, inter se, do in fact address the issues on the merits during the communications."); see Frese, 2006 WL 231895, at *7-8 (collecting cases).

130. See Stewart v. Comm'r, No. 03-271, 2004 WL 838045, at *2-3 (W.D. Pa. Mar. 1, 2004) (holding that the taxpayers had received a CDP hearing even though the SO stated that the meeting "was an informal meeting and was not the due process hearing").

131. INTERNAL REVENUE MANUAL, supra note 35, §5.1.9.3.5.

132. See id. $\S$ 5.1.9.3.8 ("CDP and Equivalent Hearing Fast Track Mediation (FTM)").

133. Id. § 5.1.9.5 ("Communications with Appeals").

134. See id. $\$$ 5.1.9.5.1 ("Disagreement with Appeals Decisions").

135. Id. $\S 5.1 .9 .3 .9 .1$.

136. See id. $\S 34.5 .4$.

137. I.R.S. Chief Couns. Mem. CC-2006-019, at 66 (Aug. 18, 2006), available at http://www.irs.gov/pub/irs-ccdm/cc-2006-019.pdf(listing all material that should be transmitted to the court for review but emphasizing that "[i]n CDP cases, the administrative record consists of all materials relied upon by an appeals or settlement officer in making a determination 
The upshot of all this is that the IRS has made the CDP "hearing" essentially a fourth stage of collection, complementing the Notice stage, ACS, and CFf. The CDP "hearing" is far from adversarial. Taxpayers may not call witnesses, ${ }^{138}$ may not demand documents from the Service, ${ }^{139}$ and have no right to examine documents or materials that the SO uses to perform the verification task. ${ }^{140}$ While taxpayers can raise issues and submit written materials, their ability to do so is no different than in any other stage of the collection process. The administrative CDP hearing is instead inquisitorial, with the SO firmly in control of the issues and information processing. CDP is simply another opportunity for the taxpayer to be classified as a "can't-pay."

Thus, it is no surprise that in almost forty percent of the CDP cases examined in this study, the same pattern emerges: the taxpayer requests a CDP hearing, the SO requests information, the taxpayer fails to provide the information, and the $\mathrm{SO}$ issues a Notice of Determination allowing collection to proceed. ${ }^{141}$ Although not usually reflected in the court decisions, the SO often asks for the exact same materials that the IRS collection employee would need to ask for, and in fact may have already asked for. ${ }^{142}$ As with every stage of collection, the SO presumes the taxpayer is a "won't-pay" and invites the taxpayer to submit information showing that he or she should be considered a "can't-pay." If the SO determines that the taxpayer is a won't-pay, the SO issues a

regarding the collection" and that, generally, "the administrative record consists of the information an agency reviews when making its determination").

138. See Treas. Reg. $\$ 301.6330-1$ (d) (as amended in 2006).

139. Barnill v. Comm'r, No. 6994-01L, 2002 WL 977364, at *3 (T.C. May 13, 2002).

140. See Nestor v. Comm'r, 118 T.C. 162 (2002) (holding that a SO was not required to give taxpayer copies of the documents used to verify the Service's compliance with applicable administrative requirement); see also Roberts v. Comm'r, 118 T.C. 365 (2002) aff'd, 329 F.3d 1224 (11th Cir. 2003).

141. While I could cite hundreds of cases, here are just a few: Kindred v. Comm'r, 454 F.3d 688 ( 7 th Cir. 2006) (taxpayers failed to provide requested financial information); Olsen $v$. United States, 414 F.3d 144 (1st Cir. 2005) (taxpayers also failed to provide requested financial information); Pennington v. United States, No. H-04-31 18, 2006 WL 1896996, at *2 (S.D. Tex. Jul. 10, 2006) (taxpayer failed to submit adequate documentation in support of his offer to compromise until after filing district court action; although district court asked IRS to review petitioners claims, the court upheld the SO's decision to reject petitions offer and impose a levy); Cohen Ent. v. United States, No. 05-1587, 2006 WL 1207956, at *1 (W.D. Pa. May 4, 2006) (taxpayer failed to provide requested documents); Frese v. United States, No. 05-1741, 2006 WL 231895, at *3 (D.N.J. Jan. 30, 2006) (taxpayers failed to respond to SO request to "describe the legitimate issues he wished to discuss"); Gardner v. United States, No. 04-2686, 2005 WL 1155728, at *1-2 (D.N.J. April 5, 2005) (SO asked taxpayer to submit a corrected return, and present specific and non-frivolous arguments; taxpayer's failure to provide either warranted dismissal); AllGlass Sys., Inc. v. Comm'r, 330 F. Supp. 2 d 540 (E.D. Pa. 2004) (SO asked taxpayer to file current returns and current financial information in order to consider collection alternatives; taxpayer failed to respond); Lister v. Comm'r, 85 T.C.M. (CCH) 774 (2003) (taxpayer failed to file requested returns or provide current financial information).

142. See, e.g., I.R.S., Telephone Conference Satisfied Collection Due Process Hearing Rights, TAX NOTES TODAY, Mar. 6, 2000, available at 2000 TNT 44-81 (LEXIS) (SO requested the exact same documents as field collection employee had requested in order to process a taxpayer's request for collection alternative). For example, if the taxpayer wants to make an Offer In Compromise, the taxpayer has to provide the same information using the same form (Form 656) regardless of whether the taxpayer submits the form to a RO or a SO. 
Notice of Determination, throwing the taxpayer back into the regular collection process stream.

This description of the "hearing" process is not a criticism of CDP. Far from it. The Office of Appeals has long been respected as an effective internal check on IRS operations. When the GAO studied the effect of the Office of Appeals on CDP hearings, it found that between sixteen and twenty-seven percent of taxpayers received a different (better) outcome after they appealed the NFTL or levy proposal. ${ }^{143}$ Almost a third of these different outcomes were because the Office of Appeals was more successful in eliciting information from taxpayers than other functions. ${ }^{144}$ One common fear was that CDP would transform the Office of Appeals into a "mini-me" Tax Court under the pressure of creating a "record" for review. ${ }^{145}$ That has not happened. As implemented, the CDP "hearing" has become essentially a separate, fourth, stage of collection, albeit one that gets court review.

In fact, as implemented, the internal review procedure is strikingly similar to another long-standing internal review program called the Collection Appeals Program (CAP). ${ }^{146}$ First implemented in 1996, CAP allows taxpayers to protest any levy, any NFTL, or any termination or rejection of an installment agreement (a main collection alternative), either before or after the action is taken, although taxpayers will generally not know when an NFTL is about to be filed. CAP hearings are like CDP and Equivalent Hearings in that the Appeals Officer "review[s] the case for appropriateness based on law, regulations, policy and procedures, ... considering all the facts and circumstances," and then issues a "closing letter" explaining the rationale for the decision. ${ }^{147}$ Importantly, the IRM instructs Appeals Officers that "[j] udgment is likely to be an issue on these types of cases although they can also involve legal or procedural issues. Appeals may reverse the Collection function's action, if evaluation of the taxpayer's history and current facts and circumstances reveal a more appropriate solution." 148

143. GAO 2006 CDP STUDY, supra note 31, at 3-4. The GAO's report found that sixteen percent of taxpayers negotiated collection alternatives with the Office of Appeals that they had not been able to negotiate before and eleven percent "fully paid their liabilities or no longer had balances due to IRS." Id. This finding means that Appeals sometimes reduces the amount owed, by abating penalties or interest, for instance. The GAO report did not specify how many of the eleven percent received reduced liabilities. Id. My personal experience suggests it was probably most of them.

144. Id. at 19-20 (finding that "when Appeals differed from Collection on the merits of the taxpayer's argument" in thirty-one percent of the cases it did so because the taxpayer gave it more information). The National Taxpayer Advocate has also noted the ability of the Office of Appeals to elicit more information from taxpayers. 2004 TAXPAYER ADVOCATE REPORT, supra note 52 , at 460.

145. See Leslie M. Book, CDP and Collections: Perceptions and Misperceptions, TAX Notes TODAY, Apr. 26, 2005, at 487, available at 2005 TNT 79-42 (LEXIS); Camp, supra note 2, at 127 ("[T]ilting Appeals towards becoming a "mini-me" Tax Court is unwise."); Pete Lowry, Thoughts on the Practicalities of the CDP Process, TAX NOTES TODAY, May 9, 2005, at 783 (2005), available at 2005 TNT 89-42 (LEXIS).

146. The CAP process is set out at INTERNAL REVENUE MANUAL, supra note $35, \S 8.24 .1$ ("Special Collections Appeals Programs Overview").

147. Id. at $\S 8.24 .1 .2 .7 .8$.

148. Id. at $\S 8.24 \cdot 1 \cdot 2.7 .10$ 
There are two main differences between CAP appeals and CDP appeals. First, taxpayers who go to CAP are generally at a later stage in the collection stream (most often in the CFf stage) where there is usually something much more individualized to complain about than an abstract threat to levy. Accordingly, taxpayers involved in CAP proceedings have a much better sense of what information they need to present to contest the levy or NFTL, allowing the Office of Appeals to obtain and review the relevant information much more quickly. That is what, in part, accounts for the second difference: CAP appeals generally are resolved in five business days whereas CDP appeals average 236 days. ${ }^{149}$ In the absence of any empirical data comparing CDP hearing outcomes with CAP hearing outcomes, one cannot conclude what, if any, value the longer CDP processing time adds to the classification task or whether it is commensurate with the increased potential for gamesmanship. I will return to this point when I discuss the costs of CDP.

\section{Judicial Review}

A taxpayer unhappy with a Notice of Determination must file a petition in Tax Court within thirty days of the Notice's issue date. ${ }^{150}$ The Tax Court uses one of two standards of review, depending on the issue appealed. First, for all challenges to the collection decision, the Tax Court reviews the administrative record to see whether the collection decision was an abuse of discretion. ${ }^{151}$ This is true for both challenges to the

149. 2005 TAXPAYER AdVOCATE REPORT, supra note 75, at 455 (based on internal information obtained from the Office of Appeals). My database shows that those CDP hearings from which taxpayers appeal to courts take, on average, 339 days. I discuss the longer processing time below.

150. See I.R.C. $\S 6330(d)(2000)$. Congress amended $\S 6330(d)$ in August 2006. Pension Protection Act of 2006, ch. 8, 120 Stat. 1019 (2006). Before Congress acted, $\S 6330$ (d) provided that appeals went to whatever court had jurisdiction over the underlying tax liability. I.R.C. $\S 6330$ (d) (2000). Thus, if the tax being collected was the type of tax over which the Tax Court would otherwise have jurisdiction (such as income, estate, or gift taxes), the taxpayer filed there. If the Tax Court would not otherwise have jurisdiction over the tax (such as employment tax liabilities and certain penalties), then the taxpayer had to file in federal district court. Taxpayers who filed in the wrong court had thirty days from the dismissal of the case to file in the correct court. See Render v. IRS, 309 F. Supp. 2d 938 (E.D. Mich. 2004) (rejecting the IRS's argument that the court was without jurisdiction to hear taxpayer's appeal because taxpayer had not waited for a Tax Court order dismissing the case before she refiled). As is typical with such taxpayer "victories," Ms. Render later lost on the "merits." Render v. IRS, 389 F. Supp. 2d 808 (E.D. Mich. 2005).

151. Goza v. Comm'r, 114 T.C. 176, 179 (2000) (relying on Conference Report language). For a time, a divided Tax Court allowed taxpayers to supplement the administrative record by introducing new evidence not submitted to the Appeals SO. It was reversed by the Eighth Circuit, which limited the abuse of discretion review to whatever record is produced. Robinette v. Comm'r, 439 F.3d 455, 462 (8th Cir. 2006), rev'g 123 T.C. 85 (2004); see also Olsen v. United States, 414 F.3d 144, 150 (1st Cir. 2005); Living Care Alternatives, Inc. v. United States, 411 F.3d 621, 631 (6th Cir. 2004). 
adequacy of CDP procedures as well as the merits of the collection decision. ${ }^{152}$ Second, for properly raised challenges to the liability decision, the Court will usually conduct a traditional adversarial trial de novo. ${ }^{153}$

\section{Continuing Jurisdiction}

Section $6330(\mathrm{~d})(2)(B)$ provides that the Office of Appeals retains jurisdiction over future collection decisions regarding the same unpaid liability that was protested in the CDP hearing. If the taxpayer "has exhausted all administrative remedies" and shows "a change in circumstances with respect to such person," then the taxpayer can ask the Office of Appeals to review the ongoing collection. ${ }^{154}$ There is not, however, any recourse to further judicial review.

Retained jurisdiction is a different concept from remand. The Tax Court and those district courts that have considered the matter have concluded that they have the ability to remand cases back to the Office of Appeals for further processing, while retaining the ability to review the subsequent decision. ${ }^{155}$ Also, the IRS has, at times, moved to remand to give the taxpayer additional process before submitting the decision to the court. $^{156}$

\section{THE FAILURE OF CDP}

"Judicial review of collection due process hearings presents a real problem for reviewing courts." 157

Tax collection requires distinguishing between taxpayers who can immediately pay the full amount due (but do not want to), and taxpayers who cannot so pay. The process is investigatory-or inquisitive-in nature and sorting "won't-pays" from "can't-pays" involves correctly applying the sorting policies created by Congress and the IRS. The premise underlying CDP was that IRS employees could not be trusted to correctly classify taxpayers as can't-pays or won't-pays. CDP promised to correct

152. See Cavanaugh v. United States, No. 03-250, 2004 WL 880442, at *6 (D.N.J. 2004) (holding that the SO's denial of a request for a face-to-face hearing and choice to proceed by telephone was an abuse of discretion); Sego v. Comm'r, 114 T.C. 604, 612 (2000).

153. Sego, 114 T.C. at 610 . If the taxpayer properly challenges his or her liability because he or she did not receive a Notice of Deficiency or otherwise did not have a prior opportunity to contest the assessed liability, the review is always de novo. Likewise, if the taxpayer challenges the liability decision by invoking the spousal relief rules in $\S 6015$ (b) or (c) the review is de novo. I.R.C. $\S 6015$ (2000). However, if the taxpayer seeks spousal relief under $\S 6015(\mathrm{f})$, the Court reviews the closed record for abuse of discretion. I.R.C. $§ 6015(\mathrm{f})$; see also Butler v. Comm'r, 114 T.C. 276, 283 (2000).

154. I.R.C. $\S 6330(\mathrm{~d})(2)(\mathrm{B})(2000)$.

155. See, e.g., MRCA Info. Servs. v. Comm'r, 145 F. Supp. 2d 194, 201 (D. Conn. 2000); Lunsford v. Comm'r, 117 T.C. 183, 189 (2003).

156. See, e.g., Ahee v. United States, No. CV-S-01-0211, 2002 WL 1023165, at*1 (D. Nev. Dec. 27, 2001); Rennie v. IRS, No. F-01-5712, 2001 U.S. Dist. LEXIS 18954, at *1 (E.D. Cal. Sept. 26, 2001).

157. Living Care Alternatives of Utica, Inc. v. United States, 411 F.3d 621, 635 (6th Cir. 2005). 
misclassification by mandating both internal review (by the Office of Appeals) and external review (by courts) to ensure the IRS got it right.

In this Part, I first present my thesis of why the CDP judicial review process cannot, in theory, add value to IRS collection decisions, and how the process harms taxpayers and hinders proper oversight of IRS collection activity. I then present the results of my empirical study of 976 decisions issued by the courts in the seven calendar years of 2000 through 2006 and discuss how they support or call into question my thesis.

\section{A. The Theory of CDP Failure}

Those who created CDP operated under a false understanding of the tax collection process. As a result, they tried to create an adversarial process check on perceived abuses. But a system that processes over 5.5 million collection accounts each year simply does not have the resources to support such an adversarial process check, either for internal or external review. As a result, the structure of tax collection tends to push, push, push at any attempted adversarial reform to bring it in line with the inquisitorial model. This is true for both internal review reforms and external review reforms.

As to the internal review, I have demonstrated above how the IRS has co-opted the required administrative "hearing" to make it part of the inquisitorial administrative process; taxpayers are still presumed to be won't-pays and must articulate-within the applicable internal operating rules-why they should be treated otherwise. As implemented, the internal review process is no different from any other part of the collection process, except that taxpayers may get access to a more experienced IRS employee who has more discretion to resolve the issues.

The external review story is similar, albeit more complex. At bottom, it is simply not possible for CDP judicial review to either catch or correct the IRS's abuse of taxpayers. Three intractable problems with interposing adversarial review on an inquisitorial process turn the great opportunity for a taxpayer's "day in court" into an empty promise. First, courts have no choice but to adopt a "record review" rule. This rule, however, prevents taxpayers from getting relevant information before the court, including, most importantly, information about changed circumstances, and so does little to solve either individualized or systemic abuse. Second, court review of the first collection decision comes too early in the collection process to add any value to the classification decision. At that stage, courts cannot add value to either the quantity or quality of the information necessary to determine whether a taxpayer is a can't-pay or a won't-pay. Finally, the inquisitorial collection process does not produce a "final agency action" within the standard administrative law meaning of that term until the final dollar is collected from the taxpayer. All decisions up to that point are interstitial; court review is simply looking at a freeze-frame of the video. Accordingly, judicial review is not proper until the tax is fully collected, at which time the Tax Code already provides a well understood structure for judicial review of tax liability, through the refund procedure, and of collection decisions, through the $\S 7433$ action for damages. I will address each of these three problems in turn.

\section{Record Review Rule Denies Relevant Information}

A court reviewing the IRS decision to levy or to file an NFTL has a choice: it can base its decision on the information available to the Service at the time the reviewed decision was made, or it can allow new information with which it can judge the merits 
of the decision. The former choice is called "record review" and is how courts typically review the actions of other agencies. ${ }^{158}$

Record review is "adversary process lite." Full-fledged adversary process-the proverbial "day in court"-promises the litigant the ability to frame the issues for decision, present supporting evidence, and test the veracity of an opponent's evidence through critical questioning and cross-examination. ${ }^{159}$ But "record review" denies litigants the ability to present the reviewing court with evidence that was not provided to the agency whose decision is under review. ${ }^{160}$ Instead, the court will only review "the record," which means whatever evidence and issues the litigant put before the agency and the agency put into its administrative files. The rationale for record review is closely tied to the rationale for the exhaustion doctrine: it preserves the agency's role as primary decision maker. To allow litigants the freedom to introduce new evidence to the court would allow them to circumvent the agency and, in effect, substitute the court for the agency as the tribunal to hear and determine a matter that Congress had delegated to the agency. ${ }^{161}$

Until 2006, the Tax Court rejected a record review rule for CDP cases. In Robinette v. Commissioner, a fractured Tax Court decided it would allow the taxpayer to introduce evidence that was not part of the administrative record. The seven-member plurality opinion boldly declared that "we are not limited by the Administrative Procedure Act (APA) and our review is not limited to the administrative record."162 The concurring opinions, however, sought to limit that statement, emphasizing that the Tax Court was not required to receive all new evidence and that taxpayers could not, with impunity, "refuse[] to comply with an Appeals officer's reasonable request for relevant evidence at the hearing." 163 Instead, the concurrences, joined by ten judges, limited the holding to times where the taxpayer "attempted to introduce relevant evidence at the Appeals Office hearing, but the Appeals officer refused to consider that evidence and failed to include it in the administrative record."164

The Tax Court's holding illustrates one of the problems with integrating broad precepts of administrative law principles into tax administration. More than almost any

158. See Fla. Power \& Light Co. v. Lorion, 470 U.S. 729, 744 (1985) ("The [Administrative Procedures Act] specifically contemplates judicial review on the basis of the agency record compiled in the course of informal agency action in which a hearing has not occurred.").

159. See Marvin E. Frankel, The Search for Truth: An Umpireal View, 123 U. PA. L. REV. 1031, 1036-41 (1975); Friendly, supra note 1, at 1291-92; Amalia D. Kessler, Our Inquisitorial Tradition: Equity Procedure, Due Process, and the Search for an Alternative to the Adversarial, 90 CORNELL L. REv. 1181, 1188-89 (2005).

160. See Camp v. Pitts, 411 U.S. 138, 142 (1973) ("[T] he focal point for judicial review should be the administrative record already in existence, not some new record made initially in the reviewing court."); United States v. Carlo Bianchi \& Co., 373 U.S. 709, 715 (1963) ("[I]n cases where Congress has simply provided for review, without setting forth the standards to be used or the procedures to be followed, this Court has held that consideration is to be confined to the administrative record and that no de novo proceeding may be held.") (italics in original); Tagg Bros. \& Moorhead v. United States, 280 U.S. 420, 443 (1930); 2 RICHARD J. PIERCE, JR., ADMINISTRATIVE LAW TREATISE $\S 11.6$ (4th ed. 2002) (collecting cases).

161. See Myers v. Bethlehem Shipbuilding Corp., 303 U.S. 41, 50 (1938).

162. Robinette v. Comm'r, 123 T.C. 85, 95 (2004), rev'd, 439 F.3d 455 (8th Cir. 2006).

163. Id. at 114 (Wells, J., concurring).

164. Id. at 116 (Thornton, J., concurring). 
other agency process, the CDP "hearing" process-particularly as transformed by the IRS as I describe above-looks far more like a part of the inquisitorial collection process than an adversarial hearing. The Tax Court's concern was that, whatever the merits of such a proceeding, the hearing did not give taxpayers an adequate opportunity to create a record for review. That intuition was best captured by Judge Wells in his concurrence: "If the Tax Court had no authority to develop a factual record in the instant case, there would not have been a sufficient record to determine whether [the SO] had abused his discretion."165

The Tax Court's concern in Robinette was neither foolish nor myopic. Judge Wells' statement reflects the Tax Court's understanding of its historic role in reviewing tax liability decisions for abuse of discretion. When taxpayers seek pre-assessment review in Tax Court of an IRS proposed liability, the Tax Court has-since its inceptionalmost always used a de novo standard of review, giving the taxpayer the standard adversarial process rights to introduce evidence, cross-examine, etc. ${ }^{166}$ Sometimes, however, the Court reviews an IRS liability decision for abuse of discretion. For example, if the IRS determines that a taxpayer's method of accounting for his or her tax does not "clearly reflect income" as required by $\S 446$ (b), the Tax Court reviews that determination under an abuse of discretion standard. ${ }^{167}$ Even here, however, the taxpayer can introduce new evidence to explain why the IRS abused its discretion. The Tax Court's focus is on getting to the right substantive result, and it has long been comfortable hearing new evidence at trial that the IRS may not have considered. ${ }^{168}$

The Tax Court was not the only trial court concerned about the status of the "record" in CDP cases, although its remedy of allowing a taxpayer to introduce evidence before the court was unique. In Mesa Oil, Inc. v. United States, the district court adopted a more traditional approach by placing the burden on the IRS to produce a record comprehensive enough for a reviewing court to make sense of. ${ }^{169}$ At issue in Mesa Oil was the adequacy of the SO's balancing determination. Recall that the SO is required to (1) verify the liability, (2) consider taxpayer arguments, and (3) balance the need for the NFTL or levy with the impact on the taxpayer. The district court in Mesa Oil was unhappy that the Notice of Determination simply recited the statutory

165. Id. at 114 (Wells, J., concurring).

166. See Barry v. Comm'r, 1 B.T.A. 156, 157 (1924) ("The record of the case made in the Internal Revenue Bureau is not before the Board except in so far as it may be properly placed in evidence by the taxpayer or by the Commissioner. The Board must decide each case upon the record made at the hearing before it, and, in order that it may properly do so, the taxpayer must be permitted to fully present any questions relating to his tax liability which may be necessary to a correct determination of the deficiency. To say that the taxpayer who brings his case before the Board is limited to questions presented before the Commissioner, and that the Board in its determination of the case is restricted to a decision of issues raised in the Internal Revenue Bureau would be to deny the taxpayer a full and complete hearing and an open and neutral consideration of his case.").

167. For an interesting discussion of the various times that the Tax Court engages in an abuse of discretion review of liability determinations, see Charles A. Boreck, Social Science Explanations for Disparate Outcomes in Tax Court Abuse of Discretion Cases: A Tax Justice Perspective, 33 CAP. U. L. REV. 623 (2005).

168. See Ewing v. Comm'r, 122 T.C. 32, 41 (2005) (Thornton, J., concurring) (listing examples), rev'd on other grounds, 439 F.3d 1009 (9th Cir. 2006).

169. No. Civ. A 00-B-851, 2000 WL 1745280 (D. Colo. Nov. 21, 2000). 
balancing test and gave no analysis for why the balancing test favored the IRS. The court believed that the record had to disclose the rationality of the decision or else court review would be a joke:

[T]here must be enough information contained in the documentation created by the IRS for a court to draw conclusions about statutory compliance and whether the [SO] abused his or her discretion. Here, the scant letters and Notice of Determination make those tasks difficult if not impossible. The government's own arguments illustrate this problem. It asserts, for example, that Mesa points to no evidence or argument offered at the due process hearing which was ignored by the [SO]. Yet the lack of a record makes it impossible to tell what was discussed at the hearing, and what factors were considered by the [SO] in making her Determination. Thus, the lack of a record erodes Mesa's statutory right to judicial review. ${ }^{170}$

While a few district courts followed Mesa Oil, the circuit courts have emphatically rejected both it and the Tax Court's approach. These courts have adopted-for understandable reasons - a very strong record review rule that significantly undermines the promise of CDP. Thus, the Eighth Circuit directly overruled the Tax Court's Robinette decision, holding that the reviewing court must confine itself to the record as presented by the agency. ${ }^{171}$ However, the circuit panel also created a kind of "heads I win, tails you lose" rule in favor of allowing the IRS-but not the taxpayer-to supplement the record:

Of course, where a record created in informal proceedings does not adequately disclose the basis for the agency's decision, then it may be appropriate for the reviewing court to receive evidence concerning what happened during the agency proceedings. The evidentiary proceeding in those circumstances, however, is not a de novo trial, but rather is limited to the receipt of testimony or evidence explaining the reasoning behind the agency's decision. ${ }^{172}$

The other circuits that have adopted the record rule have been even more emphatic in rejecting Mesa Oil's modest record review, with its accompanying remand remedy for perfecting incomplete records. In Living Care Alternatives of Utica, Inc. v. United States, the taxpayer argued that the record was inadequate to support the IRS's decision. ${ }^{173}$ There, the record consisted only of the parties' pleadings and the Notice of Determination itself. The Sixth Circuit held that the record was enough. The court concluded that in light of the historic pay-first rule and the informality of CDP

170. Id. at *7; accord Muhammad v. United States, No. C/A 0:02-2677-17BD, 2003 WL 21152978 , at * 4 (D.S.C. Jul. 15, 2003) (quoting Southmark Prime Plus, L.P. v. Falzone, 776 F. Supp. 888, 893 (D. Del. 1991) (remanding to the IRS because the record did not contain enough information for the court "to find that the Appeals Officer did not commit an abuse of discretion in rendering her decision, or that 'no relief could be granted to the Plaintiff under any set of facts that could be proved."). Note the placement of the default rule- the Appeals Officer abused his discretion unless the record shows sufficient justification.

171. Robinette v. Comm'r, 439 F.3d 455, 459 (8th Cir. 2006).

172. Id. at 461 (citations omitted) (emphasis added).

173. 411 F.3d 621, 629 (6th Cir. 2005). 
hearings, "Congress must have been contemplating a more deferential review of these tax appeals than of more formal agency decisions." "174 For courts to demand more than the "scant" record presented would mean that "the judiciary will inevitably become involved on a daily basis with tax enforcement details that judges are neither qualified, nor have the time, to administer."175

The strong record review rule presents real problems for taxpayers because they are simply stuck with the record. For example, in AllGlass Systems, Inc. v. Commissioner, the corporate taxpayers were on the hook for employment taxes and were represented by counsel. ${ }^{176}$ They timely requested a CDP hearing and proposed an Offer In Compromise (OIC) as a collection alternative. The SO asked for a personal financial statement from the taxpayers' principal owner. The owner's attorney did not meet the fifteen day deadline set by the SO who issued a Notice of Determination six weeks later that upheld the collection action against the companies. When the taxpayers tried to submit the requested information to the court in an effort to have the matter remanded, the court refused to even look at it, explaining:

As a consequence of taxpayers' failure to provide the requested information, [the SO] was faced with incomplete offers-in-compromise and therefore was unable to consider the offers as an alternative to the levy. Because of the deleterious effect it would have on the IRS's efforts to enforce the Revenue laws of the United States, taxpayers are not free to disregard administrative deadlines and, without cause, proceed at their own pace. Given these facts, the Court concludes that [the SO] sufficiently considered taxpayers' alternative collection offers, with the information available to her. ${ }^{177}$

AllGlass illustrates both the pressures that lead courts to adopt a strong record review rule and the difficulties such a rule presents for taxpayers. Worse, the IRS Office of Chief Counsel has instructed its attorneys to put forward only those documents "that support the motion for summary judgment" and no more. ${ }^{178}$ Thus unwary taxpayers may not realize--either during the hearing or after-the responsibility imposed on them in an adversarial system to ensure the completeness of the record created and sent forward for judicial review.

174. Id. at 625 .

175. Id. at 631; see also Olsen v. United States, 414 F.3d 144, 150-51 (1st Cir. 2005) (adopting a strong record review standard).

176. See AllGlass Sys., Inc. v. Comm'r, 330 F. Supp. 2d 540, 541 (E.D. Pa. 2004).

177. Id. at 547 (internal citations omitted) (emphasis added).

178. I.R.S. Chief Counsel Notice CC-2006-019, 60-61 (Aug. 18, 2006), available at $\mathrm{http}: / / \mathrm{www} . \mathrm{irs} . \mathrm{gov} / \mathrm{pub} / \mathrm{irs}-\mathrm{ccdm} / \mathrm{cc}-2006-019$.pdf. I do not suggest the IRS is trying to hide the record from court review. It is just that, as I show above, the "hearing" basically encompasses the entirety of the taxpayer account history. That is a lot of information to wade through. From the IRS's point of view, it makes sense to minimize the court's burden by simply providing the smallest amount of information necessary to support its decision. That the decision to minimize the record is administratively sound does not make it any less harmful to taxpayers. It is the taxpayer's responsibility to put into the record for review any other materials. As I argue below, that is well nigh impossible for most of the taxpayers to understand, much less accomplish. 
Despite the horrid effects of record review, CDP advocates claim that even this cursory court review adds theoretical value to the process in two ways. First, the mere possibility of review keeps the IRS employees honest. ${ }^{179}$ Second, record review allows courts to police the Service's overall collection process by shifting the court's focus from the correctness of the individual classification decision to the correctness of the administrative process resulting in that decision. ${ }^{180} \mathrm{I}$ shall address each in turn.

The "keeps them honest" claim is difficult to sustain when one realizes how rare and unusual it is, from an IRS employee's perspective, to have a court review a collection decision. For example, of the $15,822,443$ collection decisions made by the IRS between 2000 and 2006, fewer than 3,000 were likely to be reviewed by a court. ${ }^{181}$ Moreover, court review of any particular collection decision, when it happens, occurs only years after the decision, and there are several layers of management and the Office of Appeals review between the IRS employee who made the decision and the courts. So insulated-by both time and layers of bureaucracy - it would be very surprising to find any trickle-down effect of potential court review.

More fundamentally, the first claim misanalyzes the problem. The problem (misclassification) is not that nasty IRS employees work out their anger on hapless taxpayers. ${ }^{182}$ It is not personal. The misclassification problem arises from systemic decisions and bulk processing that roll over those who lack the resources to respond. It is the system that must be kept honest, not individual IRS employees.

The second claim at least focuses on the correct problem, but the remedy is wrong. Court review is neither necessary nor sufficient to police IRS collection policies. CDP proponents might cite to Crawford $v$. United States ${ }^{183}$ as a case that demonstrates how court review adds value to the IRS's systemic decisions. In that case, the district court held that the IRS abused its discretion in refusing to consider Mrs. Crawford's proposed collection alternative. ${ }^{184}$ She wanted the IRS to forbear collecting from her and instead go after her ex-husband, who was jointly liable for the unpaid tax. Mrs. Crawford said the state divorce decree had given her ex-husband both the responsibility and the resources to pay the tax. ${ }^{185}$ The district court remanded the case

179. See Leslie Book, Fix CDP, But Do Not Repeal It, A.B.A. SEC. OF TAX'N NEWSQUARTERLY, Fall 2004, at 13, 13.

180. Id. at 15 ("It is the review of agency action that provides systemic pressure for the agency to do the job right in the first place.... The focus of ... review should be (and is in other areas of the law) on what the agency did, rather than on wrestling, on an individualized basis, with the right answer ...."). The National Taxpayer Advocate has also recognized this second argument for court review and has proposed expanding court review to provide "the authority to review the entirety of the collection life cycle" so that "where the courts find that the IRS has abused its discretion, all taxpayers will benefit from the changes in procedures or additional training that result from such decisions." 2005 TAXPAYER ADVOCATE REPORT, supra note 75 , at 463 .

181. See notes $282-84$ and accompanying text.

182. This claim again betrays a nineteenth century vision of how the IRS operates. See Stanwood v. Green, 22 F. Cas. 1077 (S.D. Miss. 1870) (No. 13,300) and United States v. Fordyce, 25 F. Cas. 1143 (N.D. Ala. 1871) (No. 15,130) for examples of judicial review to check the excesses of a particular IRS agent named Stanwood.

183. 422 F. Supp. 2d 1209 (D. Nev. 2006).

184. Id. at 1214 .

185. Id. at 1210 . 
for "proper consideration" of her proposal, stressing it was doing so only because of the "limited circumstances" in which the third party was jointly liable. ${ }^{186}$

The district court's order issued in March 2006 ${ }^{187}$ Lo and behold, in December 2006 , the IRS published a policy in its IRM regarding requests to collect from third parties. ${ }^{188}$ The policy is both broader and narrower than the court's holding in Crawford. On the one hand, the policy permits taxpayers to suggest collection from third parties who are not jointly liable. On the other hand, the policy requires that the third-party assets either already be liquidated or be in the process of liquidation and sets a default period of 120 days for the third party to make payment. ${ }^{189}$

The argument that the institutional voice of the judiciary, represented by the Crawford opinion, caused a systemic change in collection policy is weak. It was not a necessary input for change. As I explain in more detail in Part IV, ${ }^{190}$ the more important institutional voices for systemic decisions are those of the Taxpayer Advocate Service, the Treasury Inspector for Tax Administration, and the General Accountability Office. Nor was the court's opinion sufficient to cause the change. Even if the court decision was one of the triggers, it only triggered a process, not the outcome. That process resulted in the following aggregate decision:

\begin{abstract}
The Settlement Officer is only required to consider taxpayer assets, not third-party assets, when evaluating a collection alternative. However, it may be appropriate in certain situations, based on the credible evidence presented, to consider the extent third party assets are available to pay the liability, and whether withholding levy while third-party assets are being liquidated may be a more efficient and less intrusive manner of collection. ${ }^{191}$
\end{abstract}

A second problem with the claim that court review can police systemic decisions is that the IRS is a bigger institutional player than any one court. The IRS must administer the tax law across the entire country, and it routinely runs up against "local" federal district courts with whose rulings it disagrees and refuses to implement. One can see evidence of this in almost every issue of the Internal Revenue Bulletin, where the IRS publishes its nonacquiescences to court decisions. Thus, a single district court decision, or even multiple circuit court decisions, will not "check" a tax administration position without the IRS agreeing to the check. ${ }^{192}$

186. Id. at 1214.

187. Id. at 1209.

188. INTERNAL REVENUE MANUAL, supra note $35, \S 8.22 .2 .4$. ("Requests to Collect from Third Parties").

189. Id.

190. See text accompanying notes 293-335.

191. INTERNAL REVENUE MANUAL, supra note $35, \S 8.22 .2 .4 .8 .1$ (emphasis in original). Even if the issue is framed as a question of "law" (as the court framed it in Crawford), it generally takes more than one trial court opinion to convince the decision makers within the IRS to change an institutional position. For example, it took the decisions of five different circuit courts over a three-year period before the IRS abandoned its systemic practice of reviving a tax liability when, due to a clerical error, it erroneously refunded a payment to the taxpayer. For a more complete description, see Bryan T. Camp, The Mysteries of Erroneous Refunds, TAX NOTES, Jan. 17, 2007, available at 2007 TNT11-55 (LEXIS).

192. See Camp, supra note 191 for one example where it took adverse decisions from five 
More fundamentally, the second claim looks only to the form of the process rather than the substance of the classification. Thus, the Crawford court was quick to emphasize that the IRS Office of Appeals need only consider Mrs. Crawford's proposal. In Brown v. Commissioner, the Tax Court went even further. ${ }^{193}$ There, the taxpayer had submitted an OIC, but the OIC was not made part of the record for court review. ${ }^{194}$ So instead of reviewing the substance of the taxpayer's offer to see whether the IRS properly rejected it, the Tax Court relied on the process used by the IRS in interacting with the taxpayer, as revealed by the SO's notes and affidavit. Thus, the court recited all the specific back-and-forths and concluded that the Office of Appeals "gave petitioner an opportunity to correct and complete financial information, yet petitioner failed to do so." 195 In essence, the SO swore to the court that the information he received was incomplete, and rather than independently reviewing the information itself, the court accepted the word of the SO. ${ }^{196}$

A more illustrative example of how the CDP record review rule elevates form over substance lies in the Tax Court's evolving approach to reviewing Notices of Determination, the decision document that the Office of Appeals issues that becomes the taxpayer's "ticket" to Tax Court review. Early on, the Tax Court allowed a taxpayer to challenge the validity of a Notice of Determination on the grounds that the IRS did not give the taxpayer a proper "hearing." ${ }^{197}$ That allowed taxpayers to obtain a court order stopping the collection action that was the subject of an invalid Notice of Determination.

The Tax Court soon abandoned a substantive review of the Notice of Determination in favor of a formal analysis. That is, it decided to presume all Notices of Determination were valid and not "go behind" them to see whether they were really so. ${ }^{198}$ If the taxpayer proved that the "hearing" was inadequate in some way then the court could remand the case to the IRS to correct the problem, but the court would not invalidate the collection decision. ${ }^{199}$ The result of this shift in review is that instead of halting collection, court disagreement delays it.

More importantly, the collection decision being reviewed just has to look good, not actually be good. If it does not look good enough, then the court's remand tells the agency to, in effect, "go back and make it look better." This was the essence of Justice Black's famous dissent in SEC $v$. Chenery Corp. ${ }^{200}$ A remand simply allows the agency to dress up its decision to look better to the court. ${ }^{201}$ The IRS just has to "consider" Mrs. Crawford's proposal and the court will most likely find no fault if the official

different courts of appeals before the IRS changed its position.

193. No. 16142-03S, 2004 WL 1775680 (Aug. 10, 2004).

194. Id. at *3.

195. Id.

196. See id. at *1-3. Mr. Brown is most likely what I call an inarticulate taxpayer who got tripped up by procedural rules. See infra text accompanying notes 207-19.

197. See, e.g., Meyer v. Comm'r, 115 T.C. 417 (2000).

198. See Lunsford v. Comm'r, 117 T.C. 159 (2001).

199. Id.

200. 318 U.S. 80, 95 (1943) (Black, J., dissenting).

201. See id. at 99 ("Of course, the Commission can now change the form of its decision to comply with the Court order."). This is precisely what happened. See SEC v. Chenery Corp., 332 U.S. 194 (1947) (Jackson, J., dissenting) ("The Court by this present decision sustains the identical administrative order which only recently it held invalid."). 
considering it swears in an affidavit that her proposal was rejected after due consideration. Thus, record review looks to form, not substance.

To sum up this first problem, CDP puts courts in something of a dilemma. On the one hand, to be effective, court review must take the approach of the Tax Court plurality in Robinette. ${ }^{202}$ Court review of a closed record does not encourage the agency to do a better job so much as it encourages the agency to create a better looking record. The National Taxpayer Advocate has argued, on this basis, for expanded court review: "Who really cares if the taxpayer has had several opportunities to ... [bring forward the information] and misses them-if the taxpayer is before us now, do we really want to collect a tax that is not, in fact, due?"203 The decision to limit judicial review to the record answers that rhetorical question with a resounding "yes." But that answer adds no value to tax administration. ${ }^{204}$

On the other hand, to allow taxpayers to introduce new evidence at the judicial review stage would make courts assume the agency's role and work the cases. Opening the record would put courts in the position of making the initial judgment as to whether a taxpayer is a true can't-pay or a clever won't-pay. Not only do courts lack the expertise of the agency employees to make a fair evaluation of the information, they also lack the resources to verify the information presented. The quality of information is a crucial aspect of making the right classification. And it is to that issue that I now turn.

\section{CDP Does Not Improve Information Quality}

Judicial review on a closed record might not be so bad if the administrative process produced a decent record. Proper classification depends upon proper information. As I have demonstrated above, one can conceptualize the entire collection process as the IRS's attempt to obtain and verify information from the taxpayer so as to make the correct classification decision. CDP neither helps the IRS acquire decent information to resolve unpaid accounts nor helps taxpayers explain their situation to the IRS and, ultimately, the reviewing court.

CDP first kicks in at the ACS stage because that is when the IRS seeks to file the first NFTL or make the first levy. By the ACS stage about two-thirds of taxpayers have already resolved their accounts either by fully paying or by convincing the IRS that they are can't-pays, thus entering into one of the collection alternatives. ${ }^{205}$ At least ninety-four percent of first levies and fifty-two percent of first NFTLs are issued automatically by $\mathrm{ACS} .^{206}$ Unresolved accounts in ACS are, by definition, owed by

202. Robinette v. Comm'r, 123 T.C. 85 (2004), rev'd, 439 F.3d 455 (8th Cir. 2006).

203. 2004 TAXPAYER ADVOCATE REPORT, supra note 52, at 459.

204. Remember, the taxpayer can theoretically bring a refund suit after fully paying the tax owed. See, e.g., Flora v. Comm'r, 357 U.S. 63 (1958); Phillips v. Comm'r, 283 U.S. 589, 59799 (1931) (finding that administrative collection of taxes comported with Fifth Amendment due process because taxpayers had a "prompt" postdeprivation action in the form of the refund suit).

205. Over two-thirds of the total amount collected on taxpayer delinquent accounts comes from the Notice stage and less than one-third comes from liens, levies, and offsets, labeled "additional actions" in the table. 2006 DATA BooK, supra note 9, at 41 tbl.16.

206. The National Taxpayer Advocate reports that, in the 2004 fiscal year, ninety-four percent of the 1.7 million CDP notices for first levies issued from ACS and fifty-two percent of 
taxpayers who are still classified as won't-pays, either because they have not responded to prior notices (I will call them nonresponsive taxpayers) or else have responded inadequately to move themselves into the can't-pay box (I will call them inarticulate taxpayers).

Conceptually, the ACS levies and NFTLs are effective at bringing in nonresponsive taxpayers. Putting aside the dedicated won't-pays, nonresponsive taxpayers are, logically, either low-functioning taxpayers who do not fully appreciate the consequences of a paper notice, or else taxpayers who are overwhelmed by life's demands and unable to adequately prioritize and respond to the notices. Levies and NFTLs help them prioritize and address the issues.

Levies and NFTLs, however, do little to help inarticulate taxpayers. Even when such taxpayers do respond, their organizational and expressive skills are so poor that they have a very difficult time explaining their situations. ${ }^{207}$ These are the types of taxpayers that bulk processing hurts the most. They have the most difficult time interacting with a bureaucracy and being heard. Their problem is often not so much the lack of an opportunity to explain their circumstances as it is the lack of their ability to (1) recognize the opportunity, (2) gather the necessary information, and (3) present the information necessary for an accurate classification.

CDP does not address the problems of either nonresponsive or inarticulate taxpayers. It is just another form sent to the taxpayer's last known address. It gives the taxpayer fewer than thirty days to jump through the proper bureaucratic hoops to request the CDP hearing. If the taxpayer misses the thirty-day deadline, the taxpayer gets an "equivalent" hearing, but no opportunity to invoke the adversarial process of court review.

As to nonresponsive taxpayers, there is no reason to believe those who did not respond to prior notices (whether out of pique or perplexity) will behave any differently toward another piece of paper. Unlike a levy, which will actually take money, freeze a bank account, or reveal their tax problems to a third party, the CDP notice does not raise the stakes. It is "same ole, same ole." As to inarticulate taxpayers, who may have indeed responded to prior notices but who have not convinced the IRS that they are can't-pays, giving them a thirty-day deadline does nothing to help them organize their thoughts, gather their materials, and present their cases. In sum, the CDP

the 0.5 million CDP notices for NFTLs came out of ACS. See 2005 TAXPAYER ADVOCATE REPORT, supra note 75, at 459 tbl.2.7.1. Combined, that means that eighty-four percent of all first levies and first NFTLs stem from the ACS stage.

207. Many sources suggest that many, if not most, of the taxpayers who fail to resolve their accounts during the Notice stage are of the type I call inarticulate. A 2006 GAO study made several findings which suggest that inarticulate taxpayers make up the largest group of those who invoke the CDP process. First, it found that the Office of Appeals was initiating more than twice as many contacts with the taxpayers as the taxpayers were initiating with the IRS. GAO 2006 CDP STUDY, supra note 31, at 20 tbl.3. This suggests that taxpayers needed considerable prompting to pursue the hearing. Second, it found that over thirty percent of the cases were closed because the taxpayer failed to respond to requests for information. Id. at 15 tbl.1.1. This suggests that a significant number of taxpayers were unable to gather and present the information needed to evaluate their claims of can't-pay. Third, although forty percent of taxpayers wanted to contest the merits of the tax liability decision, less than ten percent of those could even make the proper allegation (that they had not received a statutory Notice of Deficiency from the IRS) to enable a review of their liability. Id. at 27-28. This suggests that many taxpayers simply did not understand the scope and limitations of the CDP hearing. 
notice just gives nonresponsive taxpayers another opportunity to waste and inarticulate taxpayers another opportunity to babble. It is thus not surprising that in the one year that data is available, $98.8 \%$ of taxpayers receiving a CDP notice did not request a CDP hearing. ${ }^{208}$

The high nonresponse rate to CDP notices could support either the proposition that IRS classification decisions are right almost all of the time or the proposition that taxpayers generally agree with the presumption that they are "won't-pays." That is the reading suggested by the National Taxpayer Advocate, among others. ${ }^{209}$ Putting aside the inherent incredulity of the proposition that the IRS has an such an incredibly low error rate, a more nuanced reading of the statistics supports the claim that CDP does not give those taxpayers who disagree with the collection process either adequate notice of their peril or help for presenting the information that could correctly classify them. One sees this in looking at the relative response rate between ACS actions and field actions. Thus, although ninety-four percent of first levies issue out of ACS, only $0.86 \%$ of them trigger a CDP request, whereas over $4.2 \%$ of levies made by field personnel trigger a request for $\mathrm{CDP}$ hearing. ${ }^{210}$ While both response rates are low, it makes sense that the field response rate would be higher because it is in the field that the taxpayer will have encountered an actual, live IRS employee who presents a far more credible threat than just another bulk notice received in the mail.

The most plausible explanation for these very low response rates is that the population of taxpayers who receive CDP notices derives no benefit from the notices. The bare notice of this special hearing opportunity with the benefit of court review is insufficient to alarm these taxpayers into prioritizing their affairs. In addition, the thirty-day deadline for a written request does not help those who lack the ability to interact with the government in the first place. In both situations, CDP adds little value to the basic task of sorting out the can't-pays from the won't-pays so as to ensure proper treatment by the government. It does not help taxpayers make their case nor the IRS understand it.

208. 2005 TAXPAYER ADVOCATE REPORT, supra note 75, at 459 tbl.2.7.1 (reporting that of the 2,276,684 CDP notices issued in fiscal year 2004, only 28,133 resulted in a request for a CDP hearing). Note that a single taxpayer may be the recipient of more than one CDP notice because many taxpayers are delinquent for more than one tax period. There is no published data on how many taxpayers receive CDP notices per year, but TIGTA's 2005 Trends Report does report that the ratio of uncollected accounts per taxpayer for cases waiting action in the queue is three to one. See 2005 TRENDS REPORT, supra note 54, at 27 fig.13. Moreover, the National Taxpayer Advocate has stated that for fiscal year 2006 "taxpayers with delinquencies whose accounts were assigned to ACS for collection had an average of 1.9 delinquent tax periods, [and] taxpayers whose accounts were waiting in the ... [queue] to be assigned to field personnel had an average of 3.1 delinquent tax periods ..." 2006 TAXPAYER ADVOCATE REPORT, supra note 54, at 64 (footnotes omitted). Thus, the 2.276 million CDP notices in fiscal year 2004 probably affected between 750,000 and 900,000 taxpayers. However, since the 28,133 appeals are also counted on a per account basis and not on a per taxpayer basis, the ratio between CDP notices and appeals remains the same, whether counted as accounts or taxpayers.

209. 2004 TAXPAYER ADVOCATE REPORT, supra note 52, at 461 ("[T] he system is operating exactly as any due process review should. The vast majority of taxpayers work with the IRS or do not object to collection actions; but for those few taxpayers who do object, CDP is there.").

210. See 2005 TAXPAYER ADVOCATE REPORT, supra note 75, at 459 tbl.2.7.1. 
Lister v. Commissioner is a window into the world of inarticulate taxpayers and shows how court review adds no value to the information necessary to make a proper classification, even when the taxpayer manages to jump through all the necessary procedural hoops. ${ }^{211}$ Ms. Lister failed to file her 1993 and 1994 tax returns. ${ }^{212}$ Using third-party information, the IRS made a liability determination and sent her a Notice of Deficiency for each year. ${ }^{213}$ She did not seek the allowed pre-assessment review in Tax Court. Thus, after the IRS assessed the liability, Ms. Lister lost her ability to contest the liability decision without fully paying the tax first. Ms. Lister did, however, manage to respond to the single CDP notice issued for both years. ${ }^{214}$ She sent in the Form 12153 with this explanation of why the IRS should not collect the tax: "Claimant never received cash. Claimant received bills of credit. Claimant provides notable service. Claimant unable to meet cash demands. Claimant DNA is $75+$ years. Claimant did not file 1993 and 1994 1040A. Civil penalties don't apply. See 1040 \& Sched. R."215

Although the assigned Appeals SO tried to elicit more comprehensible information, Ms. Lister's "only contentions before the Appeals Office and before th[e] court ... were that she is disabled and unable to pay any liability and that she is entitled to a refund . . ." 216 When Ms. Lister appealed the Notice of Determination to the Tax Court, the IRS asked the court to impose sanctions against her under the authority of $\S$ $6673 .^{217}$ That section allows a court to impose up to $\$ 25,000$ in sanctions against any litigant who abuses the court's process by using it primarily to delay resolution of the case or persists in asserting frivolous arguments. ${ }^{218}$ The court refused to sanction Ms. Lister, characterizing her as merely clueless, not devious:

\begin{abstract}
We also note that the record fails to establish that all of petitioner's claims were frivolous or groundless. While petitioner's filings were confused, often unintelligible, and sometimes reminiscent of protester rhetoric, not all of the arguments contained in those filings were frivolous or groundless on their face. Petitioner's principal claim was that she is impoverished. In fact, she may well be. Unfortunately, petitioner did nothing to prove her financial condition at the section 6330 hearing before the Appeals Office. ${ }^{219}$
\end{abstract}

The Ms. Listers of the world are not protected from arbitrary IRS collection decisions by judicial review. While the IRS decision to classify them as won't-pays may or may not be correct, judicial review is not the way find out. If the legislators were truly serious about allowing taxpayers to invoke the adversarial process of court review, Congress would have adopted the Senate proposal to allow court review of all lien and levy decisions, not just the first levy or NFTL. I gave the practical reasons against that idea above. The next part explains how, under conventional notions of administrative

211. 85 T.C.M. (CCH) 774 (2003).

212. Id. at 774 .

213. Id.

214. Id. at 775 .

215. Id.

216. Id. at 177 .

217. Id.

218. See I.R.C. $\S 6673(2000)$.

219. Lister, 85 T.C.M. (CCH) at 778 (emphasis omitted). 
law, the interstitial nature of collection decisions makes such decisions inappropriate subjects for judicial review, no matter when and how they are made.

\section{CDP Are Decisions Not Proper Subject for Judicial Review}

The dynamic nature of the classification decisions and the high-volume, automated nature of the collection process are perhaps the most important reasons why adversarial judicial review adds no value to this branch of tax administration. Taxpayers start out as presumed won't-pays. To get into the can't-pay box, they must convince the relevant decision maker that they deserve a collection alternative. Even if they get a collection alternative, however, it is always conditional on future compliance, usually for five years. ${ }^{220} \mathrm{~A}$ taxpayer is always subject to reclassification, depending on the changing facts and circumstances of the taxpayer's life. The CDP provisions make certain lien and levy decisions subject to court review. But these decisions-whether they are the first or last in the series of decisions that make up the collection process-are not the proper subject for judicial review for three fundamental reasons: (1) they represent aggregate, not individual, decisions about taxpayers; (2) they are, at bottom, decisions about taxpayers but are reviewed as though they are decisions about taxpayer accounts; and (3) they are interstitial.

First, the decision reviewed by CDP is almost always an aggregate one. As I showed above, those who inserted CDP into the Tax Code assumed that the very first collection actions resulted from IRS employees deciding to levy specific property, such as a car. They thought that IRS employees misanalyzed information about a particular taxpayer or ignored a taxpayer's protests. So they fashioned a traditional remedy for situations in which one person abuses another-a court action allowing taxpayers "one opportunity to have an independent third party look at the first proposed levy action or the first actual Notice of Federal Tax Lien filing ....,221

The taxwriters fundamentally misunderstood how the IRS operates and, indeed, must operate, given that it processes over 5.5 million unpaid accounts each year. As I have shown, the initial decision to levy or file an NFTL is not an individualized classification decision; it is an aggregate decision. In fact, the ACS CDP notice represents the confluence of two great aggregate decisions: that all taxpayers are won't-pays until shown otherwise, and that the levies and NFTLs are needed to collect both dollars and information from the taxpayers who were either nonresponsive or inarticulate during the Notice stage. Thus, for all taxpayers whose accounts are processed beyond the Notice stage, this confluence of two aggregate decisions, decisions which have nothing to do with them individually, is their one and only opportunity to complain to a court that the IRS has misclassified them. It is at this point that CDP bares its paper teeth.

220. Both the Installment Agreement and OIC forms contain clauses in which the taxpayer agrees to timely file and pay all taxes for the term of the agreements (or five years for OICs). See I.R.S., FORM 9465: INSTALLMENT AGREEMENT REQUEST (2007), available at http://www.irs.gov/pub/irs-pdf/99465.pdf; I.R.S., FORM 656: OFFER IN COMPROMISE (2007), available at $\mathrm{http}: / / \mathrm{www}$.irs.gov/pub/irs-pdf/f656.pdf. The IRS monitors compliance closely and treats defaults as presumptive evidence that the taxpayer was really just a crafty won't-pay. See, e.g., Robinette v. Comm'r, 123 T.C. 85, 95 (2004), rev'd, 439 F.3d 455 (8th Cir. 2006).

221. 2004 TAXPAYER ADVOCATE REPORT, supra note 52, at 459 (emphasis added). 
The CDP remedy is simply not designed to review bulk processing decisions. The adversarial format of judicial review is designed to review individualized decisions to ensure that "a relatively small number of persons ... who were exceptionally affected, in each case upon individual grounds" have the opportunity to contest that decision as applied to them. ${ }^{222}$ In administrative law terms, ACS decisions to fire out a levy or an NFTL are the product of rules, not orders. The situation at the ACS stage is governed by Bi-Metallic, not Londoner. Until the taxpayer presents enough information for the IRS to make an individual classification decision, the taxpayer's complaint is, by definition, a systemic complaint- - a rant against the system. There is no consideration of whether the levy is appropriate for any particular asset of the taxpayer, such as a car. It's all just abstraction. It is not that the IRS is "right" to issue a levy during the ACS stage; it is simply that there are no good reasons to not do so based on the information available at the time.

Second, the decision reviewed by CDP is about collecting a liability. Court review is framed as whether or not the IRS abused its discretion in deciding to collect this liability. ${ }^{223}$ That is the wrong decision to be reviewing. As I have demonstrated, although the collection tools are used to collect dollars, they are also used to collect information from which the IRS can classify a taxpayer as a won't-pay or a can't-pay. So by reviewing the collection decision about a specific account and not the classification decision about a specific taxpayer, the court is reviewing the wrong decision. For example, if a taxpayer owes two years worth of taxes, then a court ruling that the IRS may not collect for one of those years, perhaps because the IRS has misclassified the taxpayer who is really a can't-pay, will in no way prevent the IRS from proceeding to collect the other year. ${ }^{224}$

Third, CDP requires courts to review only the first levy or NFTL. But those first decisions are not, by any means, the last. This dynamic nature of the collection process is the most intractable problem. Court review looks at only one frame in the video. Even if CDP were "reformed" to review the actual classification decisions when they occurred and on a per taxpayer basis, it would still run smack into this insurmountable obstacle to effective judicial review. ${ }^{225}$

222. The quote is Justice Holmes's famous tag line in Bi-Metallic Inv. Co. v. Colo. Bd. of Equalization, 239 U.S. 441, 446 (1915), and is commonly thought of as the great demarcation between what constitutes adjudicative action and what constitutes legislative action. Holmes was distinguishing what process was due to persons affected by legislative decisions (rules) from the process due to persons affected by adjudications. The latter was the subject of Londoner v. City and County of Denver, 210 U.S. 373 (1908). Interestingly, both Londoner and Bi-Metallic were tax cases.

223. One can look at almost any CDP case for examples of how the courts frame the question. See, e.g., Sampson v. Comm'r, No. 4170-05S, 2006 WL 1228593, at *1 (T.C. May 8, 2006) (stating that the issue is "whether [the IRS] abused [its] discretion in rejecting an offer-incompromise . . that petitioner submitted for the taxable year 2002").

224. See, e.g., Rivera v. Comm'r, 85 T.C.M. (CCH) 832 (2003); see also infra text accompanying notes $267-71$.

225. For example, Congress could provide narrowly tailored causes of action for each time the IRS rejects a collection alternative. This would at least put an individualized decision in front of a court: was the IRS correct in rejecting the taxpayer's Offer In Compromise or proposed Installment Agreement? Congress has done something similar for taxpayers who seek to undo the joint liability of a prior return. Section 6015(e) allows for judicial review of IRS 
Generally, courts review only final agency decisions. For example, section 704 of the Administrative Procedures Act (APA) provides that courts should review only "final" agency actions. ${ }^{226}$ Doctrinally, the issue is moot for CDP because the statutory scheme allows review of the first NFTL or levy decision. So, mine is not a doctrinal argument. Congress has spoken. But the reason that courts wait for agency actions to be final supports my claim that CDP court review is the wrong process at the wrong time.

To be a final agency action subject to judicial review, the action must be "the consummation of the agency's decisionmaking process . . .,227 That is, the test is applied from the agency's point of view. Simply because a decision imposes legal disabilities or liabilities does not alone make the decision final. ${ }^{228}$ The reason courts give for this requirement is that it allows the agency sufficient room to carry out its mission without excessive judicial entanglement. ${ }^{229}$ Even an interstitial decision which imposes significant costs on the plaintiff is not thereby made final. For example, in Nor-Am Agricultural Products, Inc. v. Hardin, the Seventh Circuit declined to review an emergency order issued by the Department of Agriculture that suspended a company's registration of a pesticide, thus preventing the company from using or selling the product. ${ }^{230}$ The company asked the federal courts to find that the agency had abused its discretion under the relevant statute, and both the district court and a panel of the Seventh Circuit did so. The Seventh Circuit heard the case en banc, however, and decided that the emergency order was neither a "final" order within the meaning of the organic statute nor a final agency action subject to judicial review within the meaning of the Administrative Procedure Act. ${ }^{231}$ It explained that the purpose of limiting judicial review to final orders was "to avoid delay and interference with agency proceedings by confining review to orders effectively terminating administrative adjudication. $" 232$ The emergency order was not final because the agency had procedures in place to continue the process. While from the plaintiff's point of view the decision was final because it would force the plaintiff out of business, the court applied the test for finality from the agency's view of finality, not the plaintiff's.

The aggregate collection decisions made during the ACS process are not final in the administrative law sense of final agency action. They are continually subject to modification. Levied property may be returned and NFTLs withdrawn. Rejections of collection alternatives are not final agency actions because taxpayers can come back at anytime with more or different information. The default presumption of won't-pay is

refusals to relieve spouses of joint liability. See I.R.C. $\S 6015(\mathrm{e})(2000)$. While that is not a collection decision, it is still an example of a targeted cause of action. But as I explain in the text, it would still not make sense because collection is such a moving target.

226. See I.R.C $\S 7421(2000)$.

227. Bennett v. Spear, 520 U.S. 154, 178 (1997) (emphasis added); see also Appalachian Power Co. v. EPA, 208 F.3d 1015, 1022 (D.C. Cir. 2000).

228. See Bennett, 520 U.S. at 177-78 (articulating a two-part test for determining the finality of agency actions in which "affecting legal relations" is the second part).

229. Richard J. PierCe, JR., Sidney A. Shapiro, \& Paul R. VerkuIL, AdministrattVe LaW AND PROCESS $\S 5.7 .1$ (4th ed. 2004) ("The requirement of final agency action as a prerequisite to judicial review is designed to avoid premature judicial involvement in the agency decision making process.").

230. 435 F.2d 1151 (7th Cir. 1970).

231. Id. at 1155 .

232. Id. at 1157 . 
subject to revision until the account is fully paid. And at that point, the taxpayer has the refund remedy.

The interstitial nature of the reviewed decision is highlighted by comparing it with the $\S 7433$ damage action. ${ }^{233}$ If an IRS employee willfully or negligently disregards any statute or regulation regarding collection of tax, $\S 7433$ allows a taxpayer to recover the greater of a statutory minimum or actual economic damages. ${ }^{234}$ In $\S 7433$ cases, a court reviews a discrete set of past actions taken by a specific IRS employee and judges whether those actions violated a law. ${ }^{235}$ The events being reviewed are over. What is done is done. In contrast, the actions subject to CDP review are not over; what is being reviewed is an intermediate point in the collection process which may or may not change in the future. Yogi Berra said it best: "It ain't over 'til it's over." ${ }^{236}$ And in collection, it ain't over until it's paid.

\section{Costs of CDP}

CDP's failure to live up to its promise is not benign. I count at least three costs to both the public at large and to taxpayers who are fooled into thinking that they will get their proverbial day in court. First, there is a resource cost, both within the IRS and the courts. Accepting the need for effective review of collection decisions, the CDP framework is suboptimal. Second, CDP has done doctrinal damage that has undermined the foundational role of the assessment in tax administration. Third, as it has developed, CDP threatens the symbolic legitimacy of both courts and the tax collection system. I shall discuss each in turn.

\section{i. Resource Costs}

The CDP drain on resources comes from two sources. First, many taxpayers who are correctly classified as won't-pays soak up agency and court resources that could be used to help other taxpayers or to resolve other pending litigation. While various studies have consistently reported that taxpayers who raise only frivolous, time-wasting arguments make up about five percent of administrative CDP cases, ${ }^{237}$ my study shows that they make up over thirty-seven percent of the 976 cases that resulted in court decisions between 2000 and the end of $2006 .{ }^{238}$ In both examples, this minority of taxpayers hogs a hugely disproportionate share of resources as agency or court

233. I.R.C. § 7433 (2000); see also Treas. Reg. § 301.7433-1 (as amended in 2003).

234. See Treas. Reg. $\S 301.7433-1$.

235. See generally Steve R. Johnson Code Sec. 7433: Damages Against the IRS for Wrongful Collection Actions, J. TAX. PRAC. \& Proc., Dec. 2006-Jan. 2007, at 23.

236. YOGI BERRA WITH TOM HORTON, YOGI: It AIN'T OVER ... 5 (1989).

237. See JOINT COMM. ON TAXATION, JCX-53-03, REPORT RELATING tO THE INTERNAL REVENUE SERVICE AS REQUIRED BY THE IRS REFORM AND RESTRUCTURING ACT OF 1998, at 15 (2003), available at http://www.house.gov/jct/x-53-03.pdf; GAO 2006 CDP STUDY, supra note 31 , at 17. The IRS has surmised that five percent of taxpayers hogged agency resources because "[a]ppeals personnel must often read lengthy frivolous submissions in search of any substantive issue that might be contained within the case file." Similarly, courts have to deal with even more of the same. Id.

238. See infra app. tbl.1. 
personnel slog through "lengthy frivolous submissions in search of any substantive issue that might be contained within the case file." 239 For example, in Satterlee $v$. United States, the court noted that the taxpayer's initial petition was "ninety eight pages long and difficult to comprehend at best." 240 The court diligently scoured the complaint for some substance and spent eight pages addressing it. ${ }^{241}$ Although in the great scheme of things this is not a large cost, it is a cost nonetheless.

The second cost is more direct and more substantial: delayed collection. In theory, delay costs both taxpayers and the government for the same reason: the time value of money. For every day that taxpayers delay collection, they owe additional interest and possible penalties on their taxes. For example, in Harris v. Commissioner, the petitioners properly filed and reported their tax liabilities in each of the years from 1995 to 1999 , but had not fully paid those years. ${ }^{242}$ Their unpaid taxes totaled $\$ 6,421$. However, by the time their OIC was denied on November 30, 2003, their liability for interest on their unpaid taxes totaled $\$ 7,122,{ }^{243}$ making their total liability more than double the amount of unpaid tax. The National Taxpayer Advocate has rightly noted that the accumulation of interest and penalties on those taxpayer accounts not resolved during the Notice stage will often equal or exceed the original delinquencies. ${ }^{244}$ While for tax protestors this accumulation of interest and penalties may be just the cost of their hobby, for the vast majority of taxpayers, the promise of CDP leads them further and further into debt.

The government also loses by delay. The accumulation of theoretical interest and penalties is useless if they are never collected. As the National Taxpayer Advocate notes, "delayed meaningful contacts on delinquent collection cases actually contribute to wasted resources by focusing them on inventories that are inflated by multiple delinquent tax periods . . ." 245 Just like in comedy, timing is everything in debt collection practice. It is the early creditor who usually worms the most money from the debtor. The IRS statistics in the following table tell the story; after three years, collections on each unpaid dollar reaches zero. ${ }^{246}$

Table 1. IRS Collection on an Unpaid Dollar Reaching Zero After Three Years

\begin{tabular}{|c|c|c|c|c|c|c|}
\hline Current & 1Month & 3 Months & 6 Months & 12 Months & 24 Months & 36 Months \\
\hline$\$ 1.00$ & $\$ 0.97$ & $\$ 0.72$ & $\$ 0.53$ & $\$ 0.28$ & $\$ 0.13$ & $\$ 0.00$ \\
\hline
\end{tabular}

\section{ii. Doctrinal Damage}

Court review of CDP threatens the sound development of the tax law in two ways. First, it seriously undermines the legal effect of the assessment. Recall that the tax

239. GAO 2006 CDP STUDY, supra note 31, at 17.

240. 432 F. Supp. 2d 941,944 (W.D. Mo. 2006).

241. See id. at $941-48$.

242. Harris v. Comm'r, 92 T.C.M. (CCH) 217 (2006).

243. Id.

244. See 2006 TAXPAYER AdVOCATE RePORT, supra, note 54, at 65-66.

245. Id. at 69 .

246. The table is created using data from 2004 TAXPAYER ADVOCATE REPORT, supra note 52, at 233 tbl.1.15.1 (footnotes omitted). 
assessment represents the culmination of an administrative process to determine a taxpayer's liability. When the IRS disagrees with the taxpayer's self reported liability, it issues a Notice of Deficiency, and the taxpayer may obtain pre-assessment judicial review by going to the Tax Court. But once the assessment is made, the strong pay-first rule takes over and a taxpayer who wishes to contest the assessed liability must first fully pay the liability before seeking a refund. Traditionally, therefore, taxpayers who self report their liability and whose returns are accepted by the IRS have no rights to argue for a change in an adversary forum without first fully paying the assessed liability. In short, the assessment performs the function of a judgment.

CDP undermines this role of the assessment by permitting all taxpayers who have not received a Notice of Deficiency to contest their liability through CDP, including taxpayers who self reported the liability and accordingly never received a Notice of Deficiency. This is the Tax Court's plain language interpretation of $\S 6330$ in one of the more notable taxpayer "victories" out of the 976 judicial decisions found ${ }^{247}$ Under this reading, CDP threatens the historic pay-first rule and provides taxpayers a way to end run the Anti-Injunction Act. ${ }^{248}$ Even the National Taxpayer Advocate recognizes this problem and has asked Congress to limit post-assessment court review of liability to a review of whether the IRS properly considered a taxpayer's request for an audit reconsideration. $^{249}$

The second source of doctrinal damage is the adversary process of court review, which increases the risk that bad collection policy will become bad law. For example, recall that the IRS refused to consider Mrs. Crawford's proposal that it first collect from her husband because even though they both owed the tax, she was the one who was supposed to pay. ${ }^{250}$ Whether or not the IRS should consider such a request is a matter of collection policy beyond the scope of this Article. Doing so might or might not make sense. But because the issue came up in an adversarial context where the government attorney (an attorney from the Department of Justice and not even from the IRS) was called upon to zealously advocate for his client, the government took the position that the statutory definition of "collection alternatives" must, as a matter of law, be read to exclude proposals such as Mrs. Crawford's. ${ }^{251}$ What should be a policy call becomes, in the courts, a statutory call.

247. See Montgomery v. Comm'r, 122 T.C. 1 (2004).

248. See I.R.C. § 7421(a) (2000).

249. See 2004 TAXPAYER ADVOCATE REPORT, supra note 52, at 461-63 ("Providing a second opportunity to go to court to a taxpayer who, for whatever reason, has already had one opportunity to challenge the underlying tax liability in Tax Court and missed it, diminishes the meaning of the Notice of Deficiency and pre-assessment review."); see also Danshera Cords, Collection Due Process: The Scope and Nature of Judicial Review, 73 U. CIN. L. REV. 1021, $1044-45$ (2005).

250. See supra text accompanying notes 183-96.

251. See Crawford v. United States, 422 F. Supp. 2d 1209 (D. Nev. 2006). For an excellent, thoughtful essay on the proper ethical role of government counsel, see Michael Hatfield, Fear, Legal Indeterminacy, and the American Lawyering Culture, 10 LEWIS \& CLARK L. REV. 511 (2007). It is, of course, possible that the government position was not simply a litigation position and that the Office of Appeals had sought guidance from the Office of Chief Counsel, which had concluded that the statute barred consideration of third-party payments in evaluating collection options. But that would be very strange, especially considering the CDP regulations were deliberately crafted to emphasize the broad range of alternatives that the Office of Appeals 
Another example of this effect of adversarial court review is Parker $v$. Commissioner, which, like Crawford, is another taxpayer "victory" and one which CDP advocates believe shows how judicial review checks IRS systemic abuses. ${ }^{252}$ While I count Parker as a taxpayer victory, the court's review did not uncover a systemic problem, much less fix it. Worse, the case shows how a bad collection policy might get set in law. I read Parker as a cautionary tale.

In Parker, the taxpayer sent in the proper form to request a hearing. ${ }^{253}$ The IRM instructs SOs to generally schedule hearings within thirty days and to give taxpayers fourteen days to respond to information requests. ${ }^{254}$ Treasury Regulation $\S 301.6320-1$ provides that if the taxpayer requests a face-to-face hearing, the taxpayer must be given the hearing "at the Appeals Office closest to [the] taxpayer's residence." 255 In Parker, the SO violated both directives, giving the taxpayer less than eight days to arrange to drive 180 miles to a hearing, even though there was an Appeals Office where the taxpayer lived. ${ }^{256}$ The taxpayer did not make the hearing, but managed to fax a document to the SO on the scheduled day of the hearing. The document explained that he could not make the meeting, had not had time to prepare, and wanted a face-to-face hearing in his city of residence. The taxpayer and the SO then talked on the phone. The SO heard enough, and, ignoring the taxpayer's request for a face-to-face hearing, issued the Notice of Determination approving collection action. ${ }^{257}$

In court, the IRS attorney raised a ludicrous ex post argument that the taxpayer had waived a face-to-face hearing because he had not explicitly asked for one on his initial request for a $\mathrm{CDP}$ hearing. The court properly rejected that argument and remanded the case to the Office of Appeals to give the taxpayer a face-to-face hearing. ${ }^{258}$ There was not, however, any systemic error. The aggregate collection decisions reflected in the regulations and IRM instructions were fine; as a result of the case, the IRS did not have to change one word in its regulations or the IRM. The problem was not that there was a bad operating procedure so much as it was that the IRS attorney-under the pressure of an adversary system—put out a silly ex post argument that taxpayers waive their right to a face-to-face hearing if they do not explicitly request one on the initial form. The adversary system often produces ex post defenses that, if successful, then become entrenched rules of law. Far from adding value, this case shows again the potential downside of the adversarial process. A different court, with less understanding of tax procedure, might well have bought the argument and thus entrenched an operating rule that nowhere appears in the regulations or IRM. Parker represents the potential cost of $\mathrm{CDP}$ to the system.

could consider. See Treas. Reg. $\S 301.6330-1(\mathrm{e})(3)$ (as amended in 2006).

252. See Parker v. Comm'r, 88 T.C.M. (CCH) 327 (2004). In her 2005 Annual Report, the National Taxpayer Advocate cites Parker as a case showing how "[j]udicial review is an essential component of CDP rights because in some instances the IRS collection system demonstrates ... [t] he desire to obtain efficiencies of scale at the expense of providing taxpayers with a reasonable CDP hearing ..." 2005 TAXPAYER ADVOCATE REPORT, supra note 75 , at $457-58 \& 458$ n. 70 .

253. See Parker, 88 T.C.M. (CCH) at 327.

254. See INTERNAL REVENUE MANUAL, supra note 35 , at $\S 8.22 .2 .2$.

255. Treas. Reg. $\S 301.6320-1$ (d)(2), Q \& A D7 (as amended in 2006).

256. Parker, 88 T.C.M. $(\mathrm{CCH})$ at 327.

257. See id.

258. See id. 


\section{iii. Symbolic Dilution}

Our society and culture, and particularly our legal system, have long elevated and celebrated the idea and ideal of the individual. ${ }^{259}$ Scholars recognize that adversarial process furthers that ideal in two important ways. First, it allows justice to be administered on a retail, not wholesale, level, and in a manner that respects the individual's autonomy. ${ }^{260}$ Second, it serves as a symbol of the proper administration of justice. ${ }^{261}$ I have demonstrated above how CDP court review fails the first purpose: it does not help secure the information necessary for the proper classification of taxpayers, and it rarely reviews a truly individualized agency decision about a particular taxpayer.

CDP proponents claim that Collection Due Process adds value, if for no other reason than because it provides taxpayers with a symbol that the system cares about them. ${ }^{262}$ The very use of the term "Collection Due Process" and the rhetoric used by the taxwriters in 1998 plays up the symbolic function: taxpayers get their day in court. But a symbol which is a cynical, empty, and false promise becomes pernicious and destructive. ${ }^{263} \mathrm{CDP}$ perverts courts as symbols of justice and transforms them instead into symbols of taxpayer manipulation and government oppression.

On the taxpayer side, there is one population of taxpayers who delight in CDP: those who use the process to delay payment or to promote their syphilitic politics. They might be can't-pays or they might be won't-pays, but they refuse to give up the information from which a decision can be made.

On the government side, the most egregiously cynical aspect of CDP is that it reviews only liens and levies, leaving improperly classified can't-pays vulnerable to the Service's third great collection tool: setoffs. Setoffs do not trigger CDP "rights." Setoffs happen automatically whenever the IRS computers sniff out a past-due tax

259. See generally Kermit L. HALL, THE MAGIC MiRROR: LAW IN AMERICAN HISTORY (1989) (emphasizing the growth of law as growth of individual rights against the state); PERRY MILLER, THE LIFE OF THE MiND IN AMERICA: FROM THE ReVOLUTION to THE CIVIL WAR BoOKS ONE THROUGH THREE (1965) (introducing and defending the "head/heart" dichotomy).

260. See Camp, supra note 2, at 17-20 (discussing the differences between the inquisitorial and adversarial systems).

261. See generally Jon C. Dubin, Torquemada Meets Kafka: The Misapplication of the Issue Exhaustion Doctrine to Inquisitorial Administrative Proceedings, 97 COLUM. L. REV. 1289 (1997); Mark Fenster, The Birth of a "Logical System": Thurman Arnold and the Making of Modern Administrative Law, 84 OR. L. REv. 69 (2005); Jerry L. Mashaw, The Management Side of Due Process: Some Theoretical and Litigation Notes on the Assurance of Accuracy, Fairness, and Timeliness in the Adjudication of Social Security Claims, 59 CORNELL L. REV. 772 (1974).

262. See, e.g., Danshera Cords, How Much Process Is Due? I.R.C. Sections 6320 and 6330 Collection Due Process Hearings, 29 VT. L. REv. 51, 102 (2004) ("Without a consistent process that comports with our notions of 'due process,' public confidence in the fairness, equality, and effectiveness of the tax collection system may be reduced. This risk may pose a significant threat to our system of tax collection. Taxpayers are far less likely to comply with the tax law if they believe that the tax law is unfair or that they are not afforded the same rights as others.").

263. Steve R. Johnson, The Dangers of Symbolic Legislation: Perceptions and Realities of the New Burden-of-Proof Rules, 84 lowa L. REV. 413, 415 (1999) (describing recent tax law provisions as a "pernicious exercise in symbolic legislation"). 
liability or other approved debt against which the refund may be applied. ${ }^{264}$ Yet it is the setoff of Earned Income Tax Credits (EITCs) that can cause many low income taxpayers the most problems. ${ }^{265}$ If ever there was a case to be made for pre-deprivation "hearings" of the adversarial type, it is for EITC taxpayers. Many have the "brutal need" for the credit, which is the replacement-in the form of a refundable tax creditfor the same type of welfare payments that the Supreme Court decided were important enough to require a pre-deprivation hearing. ${ }^{266}$ To the extent one believes in CDP's effectiveness, omitting these collection actions from review is outrageous; it diminishes even the symbolic value of CDP as a protector of innocent taxpayers unjustly treated by the IRS.

But wait, it gets worse. Recall that a court reviews only collection decisions about tax periods and not decisions about taxpayers. But those collection decisions are really a judgment about whether a taxpayer is a can't-pay or a won't-pay. Accordingly, if a taxpayer is faced with collection on multiple tax liabilities but can only get to court on one of them, a decision by the court that the IRS abused its discretion to collect that liability from that taxpayer is good for nothing. The IRS can still collect on the other tax period. Even if the taxpayer gets both tax periods before the court, the court may well issue a "split decision" finding for the taxpayer on one year and for the IRS on another year.

The case of Rivera v. Commissioner illustrates the cost. ${ }^{267}$ It was a "split decision" because the court disallowed collection on some of the taxpayer's accounts but allowed collection to proceed on others. ${ }^{268}$ Victory it may have been, but mostly it was a waste of everyone's time for the following reasons.

John Rivera did not file tax returns for many years. The IRS investigated and assessed tax liabilities against him for the years 1977-92, 1994, and 1997 for a total of $\$ 175,000$, with approximately $\$ 106,000$ stemming from the $1977-1983$ period and the remaining $\$ 69,000$ from the other years. Rivera had a face-to-face CDP hearing during which the SO suggested several collection alternatives to him, but Rivera never sent in the forms or information necessary to process any collection alternative. Eventually, a year after he requested his CDP hearing, the SO issued a Notice of Determination and

264. As the IRS explains on its Web site, "you may not get all of your refund if you owe certain past-due amounts, such as federal tax, state tax, a student loan, or child support. The IRS will automatically apply the refund to the [amounts] owed." I.R.S., Refund Inquiries, http://www.irs.gov/faqs/faq/0, id=199566,00.html.

265. See, e.g., Bartman v. Comm'r, 87 T.C.M. (CCH) 1213 (2004), aff'd in part, vacated in part, 446 F.3d 785 (8th Cir. 2006) (describing how one taxpayer's EITC of $\$ 3000$ was setoff when the newly divorced and unemployed taxpayer had less than $\$ 5000$ gross income). Since the IRS collected by setoff, the taxpayer had no recourse to CDP. Id. Not only does the IRS automatically setoff refunds against past tax liabilities reflected in the IRS records, but in another bulk processing decision, it also will automatically hold refunds if its records show that the taxpayer did not file a return in any one of the five prior years. INTERNAL REVENUE MANUAL, supra note $35, \S 25.12 .1 .1$. The taxpayer must then contact the IRS and show a legitimate reason for the non-filing in order to get the refund.

266. See Goldberg v. Kelly, 397 U.S. 254 (1970). Whether EITCs are "property" to the extent of triggering a constitutional due process analysis is beyond the scope of this Article. I happen to think that a good case can be made that they are.

267. 85 T.C.M. (CCH) 832 (2003).

268. See id. at 835 . 
Rivera went to have his day in court. ${ }^{269}$ The main decision by the court was that the IRS had improperly assessed Rivera for the years 1977-1983. As a result, the court barred the IRS from collecting any of those liabilities and remanded the case for further proceedings with respect to those years. ${ }^{270}$ The court spent six pages reviewing the liability decision but then took only one sentence to decide that the IRS did not abuse its discretion in collecting the other assessed liabilities. ${ }^{271}$

What did Rivera "win"? First, he won delay. Rivera successfully delayed collection of all liabilities for some 1,200 days, from February 1, 2000, the date of the CDP notice, until May 14, 2003, ninety days after the Tax Court decision. If nothing else, CDP taxpayers always "win" delay as shown by Figures 1 and 2 in the Appendix.

Rivera also won the reduction of his liabilities from $\$ 175,000$ to $\$ 69,000$ (until such time as the IRS properly reassessed the liabilities disallowed). Whether or not that is a "victory" depends on whether or not Rivera had the money to pay the $\$ 175,000$. If Rivera was truly a won't-pay, then delaying collection of $\$ 106,000$ is certainly a "victory" for him. However, that kind of taxpayer manipulation is hardly a "victory" for good tax administration. Quite the opposite, such a "victory" is an abomination. A flush Rivera should be made to pay the assessments and then litigate in a refund suit. Make Rivera fulfill his duty to report his financial transactions by bearing the burden to show that he overpaid his taxes in a refund suit. Make Rivera, and not law-abiding taxpayers, suffer the consequence of his poor record-keeping and non-compliance with his legal obligation to file returns and pay taxes.

But what if Rivera was truly just an inarticulate can't-pay? ${ }^{272}$ Where's the victory now? Now the IRS goes after him for $\$ 69,000$ instead of $\$ 175,000$. Big deal. Recall that CDP does not review the IRS classification of Rivera-as-taxpayer, it just reviews the decisions about a particular liability. To the IRS, he is still a won't-pay. The system rolls on and inarticulate taxpayers are crushed. So the IRS still levies his wages, it still seizes his car or other personalty, it still files a Notice of Federal Tax Lien, which damages his credit and impedes his ability to transfer assets. In short, it still intrudes on his life in a most unpleasant way. CDP has done nothing to help Rivera if he was improperly classified.

Assuming Rivera was really an inarticulate can't-pay, CDP is worse than useless. Mr. Rivera spent time, energy, emotion, and faith thinking he could "have his day in court." He got it, but it did not help him whatsoever. Rivera thus illustrates the cost of CDP to taxpayers. On the one hand, taxpayers properly classified as won't-pays ought not to have CDP because it simply delays the proper collection of tax at the expense of compliant taxpayers. On the other hand, improperly classified taxpayers need much,

269. See id.

270. See id.

271. See id. Since Rivera had not filed returns for those years, there was no limitation period for the IRS to assess. See generally I.R.C. §6501(c) (2000).

272. The record suggests that Rivera may have been an inarticulate taxpayer who needed a voice. See Rivera, 85 T.C.M. (CCH) at 832 (suggesting that the face-to-face conference seemed to define some issues, but that Rivera did not follow up). After he filed his petition to the Tax Court, the IRS sent him copies of Form $\mathbf{4 3 4 0}$ for all the tax periods at issue asking Rivera to admit to the truth of them. Id. at 833 . Rivera failed to respond. Id. These failures to respond and Rivera's failure to get counsel suggest that Rivera may not have had the resources to articulate his position. 
much more than what CDP gives them in order to truly have a meaningful opportunity to be heard. Part IV sketches some ideas toward the latter.

\section{B. The Study and Its Results}

The numbers support my theoretical critiques. To study the efficacy of judicial review, I gathered into a database all court decisions issued during the study period that reviewed a taxpayer appeal from a CDP hearing. ${ }^{273}$ The review period ran from the first court decision issued in January 2000 through the end of December $2006 .^{274}$ During this review period, 976 court orders addressed appeals by taxpayers from the administrative CDP process. A summary of my basic data appears in Table 1 of the Appendix. My study addressed four areas: (1) how often do taxpayers prevail in court and to what effect; (2) what effect, if any, does representation by counsel have on outcomes; (3) how many taxpayers abuse the court process by raising frivolous arguments; and (4) how much time does court review add to the collection process. ${ }^{275} \mathrm{I}$ present my findings in that order.

\section{Courts Overturn Only One-in-a-Million Collection Decisions}

To study how taxpayers fare in court, I coded cases where a taxpayer appealed from a Notice of Determination and where the court did not completely affirm the IRS decision as a taxpayer "win." Using those criteria, I counted sixty-three taxpayer wins among the 976 cases reviewed. ${ }^{276} I$ then divided the wins into three types: (1) those where the court rejected the merits of the IRS decision at issue; (2) those where the court found error in the procedure that produced the IRS decision at issue and remanded the case to the IRS to do over; and (3) those where the court's decision was interstitial-where the taxpayer had survived an IRS motion to dismiss or motion for summary judgment, and where I could find no further recorded activity in the case. ${ }^{277}$

273. My assistants searched three electronic databases to find evidence of opinions: LEXIS, Westlaw, and Tax Analysts. In addition, if upon reading a case my assistants found evidence of another court decision that had not been picked up by any of those services (such as a reported appellate decision referencing a trial court decision), they tracked it down on PACER. Once again, I must thank my assistant Lee Franks for his prodigious assistance in this matter. He was truly the Oscar Peterson of Excel and performed the heavy lifting for data input and quality control. He also rendered many of the charts and graphs and, most importantly, gave thought and care to his work. I would also like to thank my prior research assistants Ariya McGrew, Peter Hall, and John Valdez for all their help in setting up the database and doing the initial data entry. Naturally, I remain responsible for any errors.

274. The first case was Diefenbaugh v. Weiss, No. 3:99 MC 7029, 2000 WL 202705 (N.D. Ohio Jan. 6, 2000), aff'd, No. 00-3344, 2000 WL 1679510 (6th Cir. Nov. 3, 2000).

275. I initially gathered data to compare outcomes as between district courts, which handled approximately forty percent of all CDP appeals, and the Tax Court, which handled the remaining sixty percent. Note that neither the Court of Federal Claims, nor any bankruptcy court, issued any decision reviewing a CDP hearing during the review period. However, since all CDP appeals must now be taken to the Tax Court, I have not analyzed this data in this Article.

276. See infra app. tbl.2 for a listing of these cases.

277. I did not count cases as "win" cases where a subsequent decision showed that the 
The sixty-three wins broke into twenty-seven "merit" decisions, twenty-six "procedural" decisions, and ten "interstitial" decisions. Finally, I looked at whether the IRS decision at issue was one about the taxpayer's liability or about collection alternatives. Of the sixty-three wins, twenty-six concerned IRS liability decisions and thirty-seven involved IRS collection decisions.

Pegging the number of wins at sixty-three of 976 (or 6.5\%) both understates and overstates the benefit to taxpayers of CDP court review. The number understates the benefits because the 976 reported outcomes probably cover less than half of the court cases filed. In its 2006 study of CDP administrative hearings, the General Accountability Office estimated that approximately two percent of administrative decisions were appealed in fiscal year 2004. ${ }^{278}$ Given that the IRS Office of Appeals has closed approximately 149,311 administrative hearings since 1999 , it is reasonable to expect some 3,000 cases to have been appealed to courts for review. ${ }^{279}$ While the

taxpayer had lost on remand. See Newstat v. Comm'r, No. 16989-02L, 2004 WL 2075172 (T.C. Sept. 16, 2004) (upholding an IRS collection decision for one year, but remanding the case a second year for a new CDP hearing). The remand in Newstat produced the same collection decision and the court upheld it. Newstat v. Comm'r, No. 16989-02L, 2005 WL 3068347 (T.C. Nov. 10, 2005); see also Ahee v. United States, No. CV-S-01-0211-KJD LRL, 2002 WL 10223165 (D. Nev. Dec. 27, 2001) (where the government moved for the remand to give a taxpayer a face-to-face hearing). The same court later upheld the resulting decision to collect. Ahee v. United States, No. CV-S-01-0211-KJD LRL, 2002 WL 31061637 (D. Nev. July 22, 2002). Nor did I count as a "win" cases like Burt, Inc. v. IRS, No. 2:05-CV-301, 2006 WL 2797744 (N.D. Ind. Sept. 28, 2006) (where the taxpayer survived an IRS Motion for Summary Affirmance). The same court later awarded the IRS a Motion for Summary Judgment. Burt, Inc. v. IRS, No. 2:05-CV-301, 2007 WL 952009 (N.D. Ind. Mar. 27, 2007). In addition, I did not count cases like Dorn v. Comm'r, 119 T.C. 356 (2002) (where the taxpayer survived a Motion to Dismiss when the court decided it had jurisdiction to review the IRS decision to collect by jeopardy levy). Petitioner ultimately lost the case on the merits. Dorn v. Comm'r, No. 624000L, 2003 WL 21500028 (T.C. July 1, 2003). To the same effect, compare Parker v. Comm'r, 117 T.C. 63 (2001) (establishing that the tax court had jurisdiction to review), with Parker v. Comm'r, 90 T.C.M. (CCH) (2005) (upholding the IRS collection decision). Finally, I did not include as a "win" one case that was later reversed on appeal. Robinette v. Comm'r, 123 T.C. 85 (2004), rev'd, 439 F.3d 455 (8th Cir. 2006). In sum, unless I could find an adverse final outcome, I counted all remands and interstitial victories as taxpayer "wins."

278. GAO 2006 CDP STUDY, supra note 31 , at 4 . The GAO studied 208 of the 32,241 CDP administrative hearings closed by the IRS Office of Appeals in fiscal year 2004. Id. at 2.

279. This number was a bit tricky to find. First, I looked at the GAO 2006 CDP STUDY, supra note 31, at 12 fig.2, which reports that the Office of Appeals closed 126,200 hearings between fiscal year 2000 and fiscal year 2005. The 2005 TAXPAYER ADVOCATE REPORT, supra note 75, at 459 tbl.2.7.1, reports that the 2,276,684 CDP Notices issued in fiscal year 2004 generated 28,113 requests for CDP hearings. The report does not say, however, how many CDP requests were made during any other time period. Id. The $2006 \mathrm{GAO}$ study reports the number of CDP administrative case closures per year through fiscal year 2005, but does not report the number of requests. GAO 2006 CDP STUDY, supra note 31 , at 12 fig.2. Given that a CDP case takes an average of 300 days to process in the Office of Appeals, the GAO figure of 27,900 case closures in fiscal year 2005, id., correlates nicely with the Taxpayer Advocate's report of 28,133 CDP requests in fiscal year 2004. 2005 TAXPAYER ADVOCATE REPORT, supra note 75, at tbl.2.7.1. Accordingly, I used the number of case closures reported by the GAO for fiscal year 2000 through fiscal year 2005 , and then took an average to project a value for fiscal year 2006. Since the number of administrative CDP cases has been fairly steady since fiscal year 2002, it 
lack of a reported outcome in sixty percent of the cases might be mostly due to taxpayers not pursuing the matter, it is also quite possible that some taxpayers derive additional benefit because filing suit brings into the picture a new set of decision makers: IRS and DOJ attorneys. To that extent, CDP acts to provide taxpayers another chance to negotiate, to provide more information, or to present the same information to new eyes.

However, to the extent that the promise of CDP was to provide an external check on abusive collection decisions by agency personnel, the ratio of sixty-three wins per 976 decided cases woefully overstates the benefit of CDP court review. The numerator should be far smaller and the denominator should be far, far larger.

The numerator of sixty-three overstates the effectiveness of CDP court review in two important ways. First, thirteen of those decisions are "split decisions" like the Rivera case discussed above. ${ }^{280} I$ would submit that "split decisions" are of little help to taxpayers because the IRS gets the green light to continue the very types of collection actions complained of. Second, another seven are cases where CDP provides a duplicative avenue to court review. That is, these seven taxpayers would have been able to obtain equivalent court review even without CDP, so CDP added no value to them. ${ }^{281}$ That brings the numerator down to forty-three cases, including those where the taxpayer simply "won" a remand or just survived an interstitial motion. If one eliminates those, then the numerator comes down to sixteen cases where one can conclusively say that a court found that the IRS had made an incorrect liability or collection decision.

The denominator is also wrong. The promise of CDP was to provide court review of IRS collection decisions. The proper denominator should therefore be the universe of IRS collection decisions. Between fiscal year 2000 and fiscal year 2006, the IRS took

seems reasonable to assume similar numbers over the course of the calendar year compared to the fiscal year. Accordingly, I apply the two percent estimate to the number of hearings closed.

280. See supra text accompanying notes $267-72$.

281. These cases include two where the taxpayer was also in bankruptcy and sought a ruling that the IRS was thereby prohibited from proceeding with any CDP hearing during the bankruptcy. This issue could just as well be raised before the bankruptcy court, as the taxpayer did in In re Parker, 279 B.R. 596 (Bankr. S.D. Ala. 2002). Two other cases involved the taxpayer's claim of entitlement to innocent spouse relief under $\S 6015$, which the taxpayer could have just as well raised through the court review provisions in $\$ 6015(\mathrm{e})$. For a discussion of the interplay between the CDP provisions in $\$ \S 6320$ and 6330 and the Innocent Spouse provisions in $\$ 6015$, see Bryan T. Camp, The Equal Protection Problem in Innocent Spouse Procedures, TAX NOTES TODAY, July 18, 2006, available at 2006 TNT 137-C (LEXIS). Finally, three cases involved taxpayers seeking court review of the liability for the Trust Fund Recovery Penalty (TFRP) imposed by $\S 6672$. This is a penalty imposed on a responsible person for failure to properly pay withholding taxes of his or her employees. While there is no pure prepayment court review, taxpayers have to only pay one employee's withholding for one quarter to get into court. See, e.g., Fidelity Bank v. United States, 616 F.2d 1181, 1182 n.1 (10th Cir. 1980) (taxpayer paid $\$ 381$ to gain review of assessed penalty of over $\$ 36,000$ ). Once a taxpayer pays the withholding, the IRS will cease collection of the entire liability pending the outcome of judicial review. See I.R.C. $\S 6672$ (c) (2000); INTERNAL REVENUE MANUAL, supra note 35, $\S$ 5.7.7.6.2. Accordingly, the CDP provisions are simply a duplicate method for taxpayers who want to contest their TFRP liability. Notice, however, that I did not count as duplicative those cases where a taxpayer sought relief from a collection decision regarding the TFRP, only those where a taxpayer contested a liability decision. 
$15,822,443$ discrete collection actions. ${ }^{282}$ During that same period the Office of Appeals considered and closed an estimated 149,311 requests for an administrative CDP hearing. ${ }^{283}$ Of those, probably 3,000 or so resulted in petitions filed in district court or tax court. ${ }^{284}$ The table below sets out the potential figures.

Table 2. Potential Numerators and Denominators

\begin{tabular}{|l|c|c|l|l|}
\hline $\begin{array}{l}\text { Potential } \\
\text { Numerators }\end{array}$ & All Wins & $\begin{array}{l}\text { Wins less Splits } \\
\text { and Duplicates }\end{array}$ & $\begin{array}{l}\text { Wins less Splits, } \\
\text { Duplicates, and } \\
\text { Procedural } \\
\text { Victories }\end{array}$ & \\
\hline & 63 & 43 & 16 & \\
\hline $\begin{array}{l}\text { Potential } \\
\text { Denominators }\end{array}$ & $\begin{array}{l}\text { All Recorded } \\
\text { Court Decisions }\end{array}$ & $\begin{array}{l}\text { Probable Court } \\
\text { Petitions }\end{array}$ & $\begin{array}{l}\text { Administrative } \\
\text { Hearings Held }\end{array}$ & $\begin{array}{l}\text { Collection } \\
\text { Decisions }\end{array}$ \\
\hline & 976 & 3,000 & 149,311 & $15,822,443$ \\
\hline
\end{tabular}

Thus, if one asks "how often does the taxpayer win decided cases?" the proper ratio would be sixty-three wins out of 976 decisions, or $6.5 \%$ of the time. However, if one asks "how often will a collection decision be overturned by a court?" the proper ratio is sixteen to $15,822,443$, or $0.0001 \%$. In other words, courts do not disturb $99.999 \%$ of collection decisions made. That equals a ratio of one decision overturned to 988,903 collection decisions made. It is not a stretch to call that ratio one in a million. I submit that the latter question is the correct one because the promise of CDP was to provide judicial oversight of the claimed IRS abuse of taxpayers.

Note that I do not claim that the IRS commits error in only one in a million cases. In fact, I have little doubt that the IRS erroneously classifies can't-pays far, far more often than that. The point is that the adversarial process of court review is inherently ineffective to police the bulk processing of collection accounts and these numbers strongly support allowing those judicial resources to be used elsewhere.

\section{Represented Taxpayers Are Three Times as Likely to Prevail}

The second finding of my study also supports the argument that CDP adds little value to taxpayers. Taxpayers represented themselves in 741 of the 976 cases reviewed, a ratio of seventy-six percent. Yet only $4.5 \%$ of pro se taxpayers were able to convince a court that the IRS committed error, while $12.7 \%$ of represented taxpayers

282. This figure is the sum total of cases reported by the IRS in 2003 and 2006 for the years 2000-2006. I.R.S., DEP'T OF THE TREASURY, 2003 DATA BOOK 27 tbl.16, available at http://www.irs.gov/pub/irs-soi/03databk.pdf; 2006 DATA BooK, supra note 9, at 41 tbl.16. Each table breaks the collection decisions into NFTLs filed, levies issued, and seizures made. Furthermore, each table provides data for the three years prior to the year being reported. Recall that most of these collection actions were not individualized decisions. For example, ninety-four percent of all levies were the product of aggregate decisions made at the ACS stage. See supra text accompanying notes 205-07.

283. See supra note 279 and accompanying text.

284. The GAO estimated that approximately two percent of the taxpayers who requested an administrative hearing during fiscal year 2004 later sought court review. GAO 2006 CDP STUDY, supra note 31 , at 4. 
gained some sort of relief or survived a dispositive motion, as the following table illustrates.

Table 3. Taxpayer Legal Representation and Outcomes in CDP Cases

\begin{tabular}{|l|c|c|c|c|}
\hline Representation & Number of Cases & Percent of All Cases & Number of Wins & Win Percent \\
\hline Pro se & 741 & 75.9 & 33 & 4.5 \\
\hline $\begin{array}{l}\text { With } \\
\text { Representation }\end{array}$ & 235 & 24.1 & 30 & 12.7 \\
\hline Total & 976 & 100 & 63 & 6.5 \\
\hline
\end{tabular}

This finding is ambiguous. On the one hand, it supports a hypothesis that, in an adversary process, professional representation helps the taxpayer find "voice." Professionals are far less likely to goof up technical rules of pleading, such as failing to raise all arguments in the administrative hearing. ${ }^{285}$ The case of Brown $v$. Commissioner illustrates this point. ${ }^{286}$ There, the taxpayer failed to raise in his pleading "a spousal defense or make a valid challenge to the appropriateness of respondent's intended collection actions. These issues are now deemed conceded." ${ }^{287}$ Mr. Brown got tripped up by Tax Court Rule 331(b)(4), which provides that a taxpayer's petition must raise all issues and "[a]ny issue not raised in the assignments of error shall be deemed to be conceded. Each assignment of error shall be separately lettered." Even if Mr. Brown had raised these issues during the administrative process, and even if $\mathrm{Mr}$. Brown had carefully ensured that the proper record got before the Tax Court, Mr. Brown also needed to be sure to mention these issues in his pleading. This first hypothesis assumes that all claims have roughly equal merit, but that only those who can afford representation can get their message across. The others have no choice but to go it alone because they cannot afford to hire a professional voice.

On the other hand, the finding might support an argument that legal professionals perform a screening function. Taxpayers whose cases have merit are more likely to find someone to represent them, and taxpayers who seek to raise only frivolous claims are less likely to find representation. I cannot rule out this hypothesis entirely, especially when one considers the high percentage of frivolous claims made on appeal to courts. However, in its study of administrative CDP hearings, the GAO noted that "most individuals were lower-income taxpayers with varied liability amounts."288 Specifically, it found that fifty-four percent of CDP requests came from taxpayers

285. One of the main technical pleading rules provides that a taxpayer may not seek court review of an issue that the taxpayer did not mention during the administrative hearing. Treas. Reg. § 301.6330-1(f)(2) (2006); see also Bourbeau v. Comm'r, No. 6896-02L, 2003 WL 1918920 (T.C. Apr. 22, 2003). While normally it is pro se taxpayers who commit this error, counsel can do so as well. See Bruce v. Comm'r, No. 24303-05L, 2007 WL 1793448 (T.C. June 21,2007 ) (refusing to consider a taxpayer's request for penalty abatement because, while the taxpayer appeared to raise an issue of liability in his request for CDP hearing, "petitioner's representative stated at the hearing that no such challenge to the amount of assessment existed. Accordingly, in this proceeding we do not consider petitioner's underlying tax liability.").

286. No. 16142-03S, 2004 WL 1775680 (T.C. Aug. 10, 2004).

287. Id. at *3.

288. GAO 2006 CDP STUDY, supra note 31, at 25. 
whose adjusted gross income was less than $\$ 50,000 .{ }^{289}$ I submit that this finding makes the first hypothesis more plausible than the second.

\section{Frivolous Cases Account for One-Third of All Cases}

Many CDP commentators and participants were concerned that CDP would serve to fuel the fires of taxpayers who sought to raise only ideological arguments. In its early years, CDP was indeed a "boon to tax protestors and a pain to everyone else." $" 290 \mathrm{My}$ data show that political tax protestors were the main users of CDP in 2002 and 2003. In 2002, 100 of the 204 court decisions (forty-nine percent) labeled the taxpayer arguments as "frivolous" or "tax protestor" arguments. In 2003, it was 100 out of 190 cases (fifty-two percent) that did so. But the data, as detailed in the graph below, shows a decreasing percentage of cases attributable to this group in later years. ${ }^{291}$ The decline directly correlates with the rise in court-imposed monetary sanctions. The strong correlation between imposition of sanctions and decrease in protestor cases detailed in my graph suggests that imposition of court sanctions is effective, at least as to a relatively small and well-connected community like political tax protestors.

Figure 1. CDP Cases and Sanctions

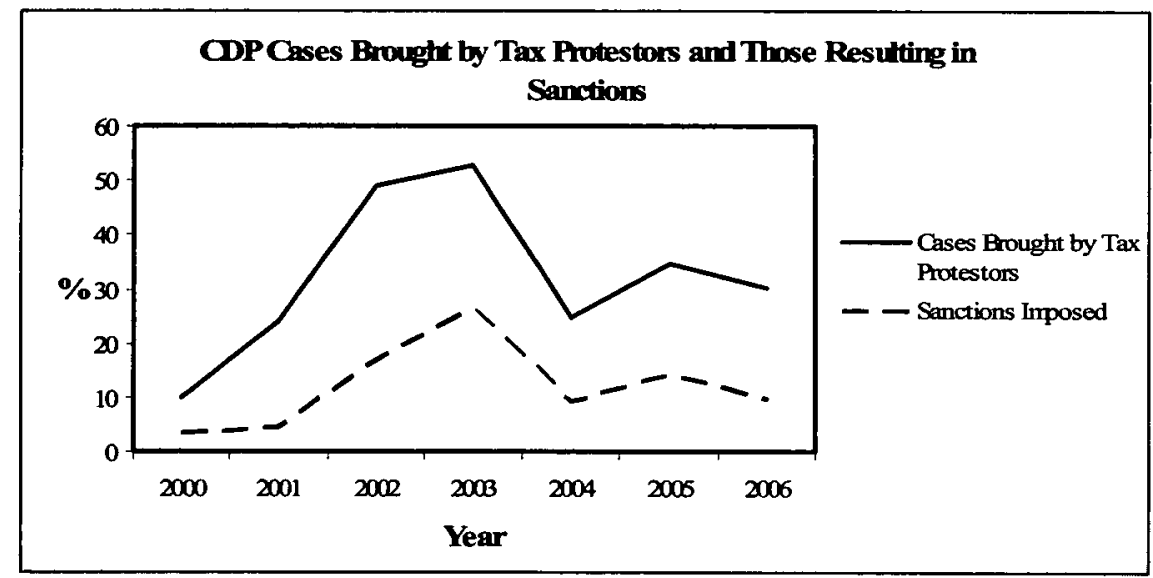

4. Collection "Delay" Process

My last finding is that CDP might as well be called "Collection Delay Process." Court review adds substantially to the delayed collection of accounts that should be collected, and the delay occasioned by court review is only getting worse over time.

Recall that when a taxpayer timely requests a CDP Hearing, the taxpayer stops the IRS from using two of its three great administrative collection tools: the NFTL and the levy. To determine the delays attributable to each stage in CDP, I took from the decisions the following three dates: (1) the date on which the IRS issued the CDP notice ("Notice" date); (2) the date on which the IRS Office of Appeals issued its

289. Id.

290. Camp, supra note 2, at 122.

291. See infra app. tbl.1 for the data used in making this graph. 
Notice of Determination that formed the basis for the court appeal ("Determination" date); and (3) the date of a trial court's final order disposing of the case before it ("Disposition" date). Not all cases yielded all three data points, even after searching PACER. The following table shows the results and the number of cases on which the results are based.

Table 4. Mean Processing Time in Days

\begin{tabular}{|l|c|c|c|c|c|c|c|c|}
\hline $\begin{array}{l}\text { Year } \\
\text { (Total cases decided that year) }\end{array}$ & $\begin{array}{c}2000 \\
(30)\end{array}$ & $\begin{array}{c}2001 \\
(46)\end{array}$ & $\begin{array}{c}2002 \\
(204)\end{array}$ & $\begin{array}{c}2003 \\
(190)\end{array}$ & $\begin{array}{c}2004 \\
(171)\end{array}$ & $\begin{array}{c}2005 \\
(179)\end{array}$ & $\begin{array}{c}2006 \\
(156)\end{array}$ & $\begin{array}{c}\text { Avg. } \\
\text { Days }\end{array}$ \\
\hline Notice to Determination & 201 & 314 & 315 & 332 & 402 & 357 & 372 & 328 \\
& $(10)$ & $(23)$ & $(122)$ & $(133)$ & $(125)$ & $(149)$ & $(97)$ & \\
\hline Determination to Disposition & 324 & 407 & 436 & 486 & 558 & 566 & 627 & 486 \\
& $(15)$ & $(30)$ & $(155)$ & $(153)$ & $(145)$ & $(149)$ & $(122)$ & \\
\hline Notice to Disposition & 511 & 703 & 762 & 840 & 956 & 936 & 1,010 & 817 \\
& $(17)$ & $(29)$ & $(135)$ & $(146)$ & $(130)$ & $(137)$ & $(110)$ & \\
\hline
\end{tabular}

My data show that the administrative portion of CDP delays collection by an average of 328 days, and court review (up to trial court disposition) adds an average of 486 days. ${ }^{292}$ As the following graphs demonstrate, moreover, not only is the delay attributable to the courts greater than that attributable to the administrative hearing process, but it is growing at a more rapid rate.

Figure 2. CDP Processing Times

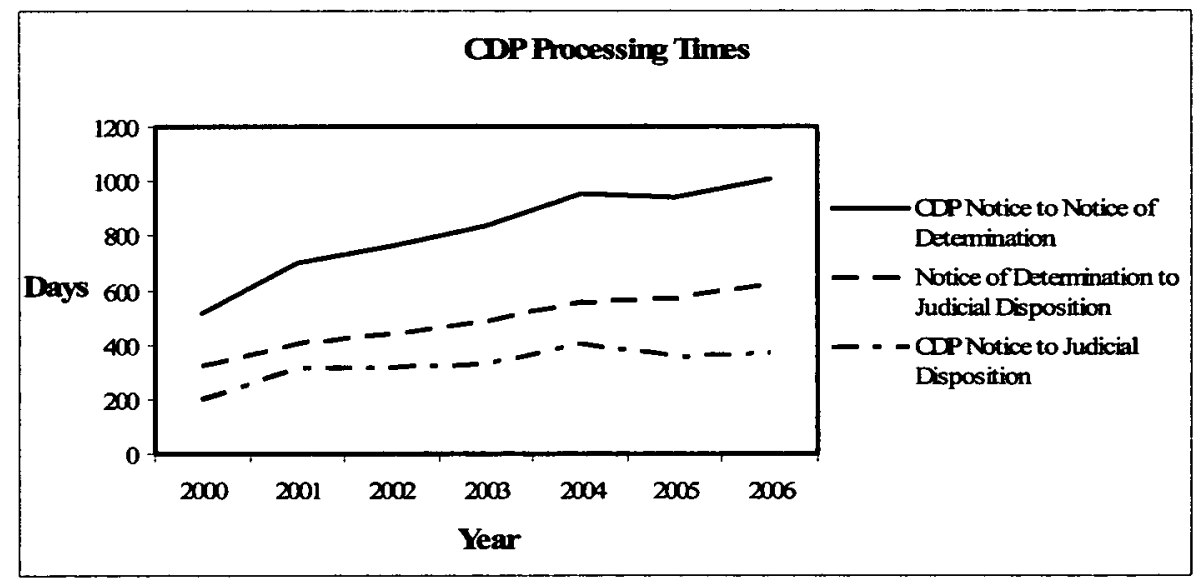

292. See infra app. tbl.2. This figure is consistent with figures presented by researchers who have studied this subject in the past. In a study of fiscal year 2001 CDP cases, the Taxpayer Advocate found an average CDP appeals processing time of 300 days. NAT'L TAXPAYER ADVOCATE, I.R.S., 2003 ANNUAL REPORT TOCONGRESS 47 (2003). In a study of fiscal year 2004 CDP cases, the GAO found an average cycle time of 314 days for cases involving nonresponsive taxpayers - those who were either completely unresponsive to all contact attempts initiated by the Office of Appeals, as well as those who ultimately failed to provide the information requested by the Office of Appeals. GAO 2006 CDP STUDY, supra note 31, at 27. 
This data supports the critique given above in Part II.A.4 that that CDP entails resource costs to both taxpayers and the government.

\section{The Rule of LAW AND INQUISITORIAL DUE PROCESS}

"II]n America the law is king. For as in absolute governments the King is law, so in free countries the law ought to be king; and there ought to be no other."293

This Part examines the claims by CDP proponents that adversarial judicial review of IRS collection decisions is necessary to, or at least advances, rule of law principles. After unpacking the claims, I shall explain how my study refutes them, and then I shall suggest how an inquisitorial-grounded process of tax collection conforms more to mainstream notions of rule of law and due process than does an adversarial-grounded process.

\section{A. Rule of Law Claims}

The phrase "rule of law" contains some deep ambiguities. ${ }^{294}$ For example, theorists have historically disagreed over whether the idea necessarily contains moral content, is morally neutral, or is a useless social construct. ${ }^{295}$ However, modern mainstream theorists appear to agree on at least two core components of the concept. ${ }^{296}$ First, the

293. Thomas Paine, Common Sense, reprinted in Thomas Paine: Collected Writings 1 , 34 (Eric Foner ed., 1996) (1776) (emphasis in original).

294. See generally BRIAN TAMANAHA, ON THE RULE OF LAW: History, POlTtCS, THEORY (2004) (reviewing historical conflicts over meanings associated with rule of law).

295. Compare, e.g., LON M. FULLER, THE MORALITY OF LAW (1964) (arguing that moral content inheres in the rule of law), and JOSEPH RAZ, THE AUTHORITY OF LAW: ESSAYS ON LAW AND MORALITY (1984) (arguing that rule of law has no necessary connection to systems of morals), with Gary Peller, The Metaphysics of American Law, 73 CAL. L. REV. 1151 (1985) (arguing that rule of law is an empty phrase, used as a rhetorical device by the powerful to subjugate the powerless). For an example of the contemporary debate see Hamish Stewart, Incentives and the Rule of Law: An Intervention in the Kramer/Simmonds Debate, 51 АM. J. JURIS. 149 (2006) (recounting and participating in an ongoing debate between two particular theorists). I am somewhat puzzled by this debate, which seems little more than exercises in boxdrawing, at least to my admittedly untrained eye. After all, few would disagree with either of the following statements: (1) the United States legal system followed the rule of law from 1789 through 1865; and (2) during that time period, the laws that treated certain categories of humans as property were immoral, even though democratically enacted and impartially enforced. See generally A.E. Keir Nash, Reason of Slavery: Understanding the Judicial Role in the Peculiar Institution, 32 VAND. L. REV. 7 (1979) (demonstrating the impartiality and formalism of slave law application). To claim that immoral legal systems cannot "qualify" as following the rule of law, it seems to me that one must reject one of those propositions. If one cannot, then one must concede that even systems imposing immoral obligations or conferring immoral benefits may do so per the rule of law. Since that is unsatisfactory, one must then create another analytical box to decry the immoral legal regime. See RAZ, supra, at 307 ("[c]onformity to the rule of law is a virtue, but only one of the many virtues a legal system should possess.").

296. I leave out the deconstructionists, like Professor Peller, from any further consideration since their main purpose is to remind us why all theories are ultimately social constructs. While 
legal rules of the state, properly enacted, must apply with equal force and effect to all members of the state, regardless of their position in the societal power structure. ${ }^{297}$ This is the idea encapsulated by the phrase "no person stands above the law." Second, the legal system must contain structural mechanisms to prevent the arbitrary administration of the laws by individuals, whether acting as dictators, kings, or bureaucrats. ${ }^{298}$ This idea is often expressed as an antithesis, contrasting the rule of law with the rule of mere mortals. Both of these common concepts find concrete expression in our own legal system through the Fifth Amendment of the Constitution of the United States, which requires "due process" before the government may deprive a citizen of life, liberty, or property. ${ }^{299}$

CDP proponents say that judicial review of IRS tax collection decisions is necessary to either preserve or promote these procedural aspects of the rule of law. The rhetoric of the commentators echoes the rhetoric of the congressional taxwriters discussed above in Part I. For example, Les Book claims that, prior to CDP, "Congress and the Supreme Court ... exempted the IRS from procedural regularity and external checks on agency discretion, both of which are associated with rule of law principles. ${ }^{, 300}$ As a consequence, he says, the IRS had "almost absolute discretion in collecting taxes and considering the merits of taxpayer requests for collection alternatives." ${ }^{301}$ Thus, Professor Book concludes that both the administrative hearings and their judicial review "comprise a step in the progression of the rule of law ...."302 CDP is necessary for "procedural regularity" and is a necessary "external checks on agency discretion" to prevent the arbitrary administration of the tax collection laws by IRS employees. ${ }^{303}$

Similarly, Danshera Cords claims that "judicial review is one of the most important aspects of CDP." 304 She asserts that "[w] here different taxpayers are afforded different rights based on arbitrary factors, such as the area in which they live or whether they have been assessed income tax deficiencies or penalties that require consideration by the district court, the notion of due process is lessened." ${ }^{305}$ While Professor Cords does not explicitly justify her conception of judicial review as necessary to preserve or

that is all well and good, it does not help figure out which social constructs are preferable or possible.

297. See FULLER, supra note 295 , at 81 (describing the congruence between official action and declared rule as one of the eight elements of a legal system that conforms to a "rule of law"); RAZ, supra note 295, at 210-13; TAMANAHA, supra note 294, at 114-19 (asserting this idea to be "a thread that has run for over 2,000 years, often frayed thin, but never completely severed ...").

298. See FULLER, supra note 295 , at 81 (locating in courts the task of preventing "the lawless administration of the law"); RAZ, supra note 295, at 216-17 (discussing the importance of an independent judiciary); TAMANAHA, supra note 294, at 122-26.

299. U.S. Const. amend. V; see Lawrence M. Friedman, Law, Lawyers, and Popular Culture, 98 YALE L.J. 1579, 1603 (1989) ("Lawyers are taught and trained to regard 'due process' as the very essence of fairness and the rule of law."). Of course, "due process" is itself a conceptual box of many colors (and mixed metaphors).

300. Book, supra note 3, at 1161 .

301. Id. at 1162 .

302. Id. at 1161 .

303. Id.

304. Cords, supra note 249 , at 1024.

305. Cords, supra note 262, at 107. 
promote rule of law values, her articles on CDP emphasize the necessity of procedural regularity and national uniformity and she frequently adverts to "due process."306

Finally, Nina Olson, the National Taxpayer Advocate, has been a staunch proponent of judicial review of CDP hearings. In each of her Annual Reports to Congress since 2003, she has reported that the CDP regime has been the number one tax issue litigated in federal court. Ms. Olson considers this a good thing, because "over time, the true value of CDP judicial review would emerge. ${ }^{307}$ Her specific claim is that court review "brings IRS collection practices, and the attendant judicial oversight, within established administrative law and practice." ${ }^{308}$ Similarly to Professor Cords, Ms. Olson is not explicit on just what "established administrative law" benefits are conferred on tax administration by judicial review of CDP hearings. She instead jumps from broad generalizations to specific cases. For example, in her 2006 Annual Report she claims that

each of the 195 cases decided during the period under review tells an important story. Because the filing of a lien and levying upon property are some of the most intrusive actions the IRS can take against a taxpayer, each case provides information about how taxpayers and the IRS behave and how problems can be avoided. ${ }^{309}$

Ms. Olson does not explain why judicial review is necessary for tax administrators to learn either the "important story" or the "information about how taxpayers and the IRS behave."

Taken together, it is fair to characterize these claims as focusing on the procedural aspects of rule of law principles. The repeated contention is that without judicial oversight, the IRS will act contrary to rule of law principles because it will act with absolute discretion. The IRS will treat similarly situated taxpayers differently based on "arbitrary factors," such as where they live. The strong claim is that judicial oversight of tax collection decisions is necessary to conform tax administration to rule of law principles. The weak claim is that judicial oversight "furthers" rule of law principles. Both claims are empty.

306. Professor Cords's latest article reiterates both her assertion that judicial review is necessary and her concern that it can add value only if done properly. See Danshera Cords, Administrative Law and Judicial Review of Tax Collection Decisions, 52 ST. Lous U. L.J. 429, 477 (2008) (asserting that "[a] consistent approach to judicial review of tax collection decisions will benefit taxpayers and tax collection administration"). Her approach is to limit court involvement to a review of the record in existence at the time of the administrative hearing. $I d$. Her article, however, neither addresses the problems that I identify above, nor explains why judicial review is a necessary component of procedural regularity. Professor Cords simply assumes that judicial review is intrinsically good.

307. 2006 TAXPAYER ADVOCATE REPORT, supra note 54, at 556.

308. Id. at 557 .

309. Id. at 561 . 


\section{B. Refutation of Claims}

My study of CDP's role in the tax collection process refutes the claim that judicial review of tax collection decisions is either necessary or helpful for tax administration to be consistent with rule of law principles. This is so for three reasons.

First, my study shows how CDP proponents mistake the problem. A proper rule of law analysis requires a full appreciation of the bulk processing nature of modern tax administration. Professor Book notes that the IRS has almost absolute discretion in making collection decisions but does not acknowledge that the most important collection decisions are made as to entire populations of taxpayers and not individual taxpayers. As explained in Part $I$, the single most important aggregate decision is to label all delinquent taxpayers as won't-pays. Since taxpayers have the information, it is reasonable to make them come forward with that information to show the IRS that they are can't-pays and not won't-pays. When they do, the IRS employee's decision is then bounded by complex sets of rules and requirements, set out in the relevant parts of the Internal Revenue Manual. For example, if a taxpayer wants to avoid a levy by obtaining an Offer In Compromise, the taxpayer must follow rigid processing rules and strict eligibility rules. ${ }^{310}$ Those rules are aggregate decisions and leave little room for discretion on the part of the IRS employee. While it is correct to say that, as an institution, the IRS has "absolute discretion," it is incorrect to make that same claim about individual IRS employees.

The problem is not that either employees or the IRS act lawlessly. Ironically, it is precisely because tax administration is so rule-bound that hardship occurs. When the rule of law becomes the law of rules, taxpayers suffer. Take levies for example. Congress properly enacted $\S 6331$ to empower the IRS to levy on a delinquent taxpayer's property or rights to property within thirty days of the IRS sending notice and demand for an unpaid tax. The IRS operationalized the levy power by deciding, in the aggregate, to give taxpayers not one, not two, not three, but four or even five notices and demands for payment before sending out levies. No one could reasonably argue that either the statute or its implementation were inconsistent with the rule of law. Every delinquent taxpayer is treated the same-everyone is presumed to be a won't-pay and everyone who does not respond gets hit with a levy, regardless of his or her geographic location or his or her status in the societal power structure. There has been no credible evidence presented suggesting that IRS employees abuse individual taxpayers during the tax collection process. ${ }^{311}$

The rhetoric that judicial review is needed to promote rule of law values thus mistakes the problem by confusing arbitrary results with incorrect results. It is undoubtedly true that some taxpayers are misclassified and, as a consequence, suffer hardship. But the mere misclassification of a taxpayer is not the same as an abuse of discretion by an employee of the IRS. The problem is not that the IRS or individual employees are abusing discretion in the moral sense of the term "abuse." The problem is simply the error that inevitably occurs in any administrative system. A taxpayer has always been able to contact the IRS, both before and after a levy is issued, to ask for

310. See generally INTERNAL REVENUE MANUAL, supra note 35, at ch. 5.8; GAO OIC STUDY, supra note 72.

311. For an in-depth discussion of the failure of evidence see Camp, supra note 2, at 80-81; see also Cords, supra note 262, at 52. 
and receive a decision about his or her ability to pay. All that the administrative hearing provisions of CDP add to the tax collection system is a single additional opportunity to have a more experienced IRS employee apply those rules to the information presented by the taxpayer.

The question thus becomes whether judicial review of this single additional tax classification decision is either necessary or helpful in promoting the rule of law. Once the question is properly framed, the second reason why judicial review does not further rule of law values becomes evident: courts are not being asked to create legal rules or settle disputed points of law - to say what the law is - but are instead asked to identify and correct erroneous classifications. They are performing neither the function of lawgivers nor of original fact-finders. My study shows how courts become simply another layer of decision makers who work the case-and do so rather poorly. Because they are far removed from the field and work with only a skimpy paper record, their decisions, whether in favor of the taxpayer or not, are inherently more arbitrary than the decisions being reviewed. In the role of a super caseworker, they lose their ability to promote the rule of law much as an appellate court does when deciding an appeal on a "totality of the circumstances" standard. Justice Scalia explains:

\begin{abstract}
To reach such a stage [where the appellate judge decides the case on the totality of the circumstances] is, in a way, a regrettable concession of defeat-an acknowledgement that we have passed the point where "law," properly speaking, has any further application. And to reiterate the unfortunate practical consequences of reaching such a pass when there still remains a good deal of judgment to be applied: equality of treatment is difficult to demonstrate and, in a multi-tiered judicial system, impossible to achieve; predictability is destroyed; judicial arbitrariness is facilitated; judicial courage is impaired. ${ }^{312}$
\end{abstract}

The third way in which my study refutes any claim that judicial review promotes rule of law values lies in the small number of taxpayers who even try to obtain court review. Courts cannot adequately police the exercise of agency discretion if they are not presented with the opportunity to review the discretion in the first place. In the CDP context, this means that taxpayers must take the initiative to file a court petition after the IRS refuses to reclassify them as can't-pays. My study shows not only that the most miniscule percentage of eligible taxpayers seek judicial review in the first place, but also explains why that is so: the combination of lack of resources and lack of ability stymie the very taxpayer who might benefit the most from yet another level of review. When courts are reversing only about one out of 1,000,000 collection decisions, it is fair to say that judicial review adds nothing to the rule of law.

\title{
C. Inquisitorial Due Process
}

The main concern of CDP proponents is an important one: taxpayers should be properly classified so that they receive the proper treatment. We all want the IRS to reach the "right" result for each taxpayer. In the context of tax collection, that means we want the IRS to administer its collection programs so that taxpayers are properly

312. Antonin Scalia, The Rule of Law As a Law of Rules, 56 U. CHI. L. REv. 1175, 1182 (1989). 
classified. CDP proponents, however, might want more. They might argue that judicial review is "due" taxpayers, not because the rule of law demands it, but because our conception of justice demands it. This last section explores that idea.

As discussed above, the demand for judicial review is not justified by rule of law principles. Nor, as my study shows, can the demand for judicial review rest on instrumentalist grounds: courts are simply a very poor structural mechanism to ensure that the IRS reaches the right result. However, there might be a moral claim based on a concept of justice that always requires adversarial process as part of the process "due" taxpayers. Such a claim would rest on what Professor Jerry Mashaw calls the "moral judgment" model of justice. ${ }^{313}$ CDP proponents demand an adversarial review mechanism not simply to correct errors, but also to pass judgment on the process and the parties. In his study of the Social Security Administration's processing of disability claims, Jerry Mashaw contrasted that model of justice with what he called the "bureaucratic rationality" model. ${ }^{314}$

These models have different goals and operational structures. Briefly, the bureaucratic rationality model seeks to distinguish can't-pays from won't-pays as efficiently as possible (i.e., more outcomes per unit of resources used to generate the outcomes). The goal is simply to discover whether the taxpayer has sufficient assets to pay the liability in full. In contrast, the moral judgment model seeks to determine "the deservingness of some or all of the parties in the context of certain events, transactions, or relationships that give rise to a claim." ${ }^{315}$ In Professor Mashaw's study, the moral judgment called for was the deservingness of injured workers to Social Security Disability payments. In the context of tax collection the judgment called for is the deservingness of taxpayers to be free from coercive collection or, put another way, the deservingness of the IRS to collect (if it can) from the taxpayer.

The choice of process reflects the choice of goals. The bureaucratic rationality model chooses a process that seeks to develop the most relevant information at the least cost. The scope of what information is relevant is relatively narrow and focuses on assets. This model relies on the integrity of prior processes that have produced the tax liability determination. In contrast, the moral judgment model seeks to maximize a "contextualized exploration of individual deservingness" 316 in which, in the words of $\S$ 6330 , the taxpayer may raise "any relevant issue relating to the unpaid tax or the proposed levy." ${ }^{317}$ Not surprisingly, this conception of justice leads to an emphasis on adversarial process, as Mashaw demonstrates. ${ }^{318}$

313. Jerry L. MaShaw, Bureaucratic Justice: Managing SOCIaL DisabiltTy Claims 2931 (1983).

314. Id. at $25-26$.

315. Id. at 30.

316. Id.

317. I.R.C. $\S 6330(\mathrm{c})(2)(\mathrm{A})(2000)$.

318. MASHAW, supra note 313, at 30. The struggle over administration of Social Security Disability claims illustrates the resiliency and power of the idea that adversarial process is a necessary component of the administrative state. Professors Paul Verkuil and Jeffrey Lubbers have documented twenty-five years worth of failed attempts to remove or reduce the role of adversary process in making or reviewing Social Security Administration disability determinations. See Paul Verkuil \& Jeffrey Lubbers, Alternative Approaches to Judicial Review of Social Security Disability Cases: A Report to the Social Security Advisory Board, 44 ADMIN. 
The CDP debate can be seen as a debate about these two concepts of justice. I have previously explored how those who created CDP sought to shift the tax administration paradigm from an inquisitorial one to an adversarial one. ${ }^{319}$ In Mashaw's terms, that is simply another way of stating that CDP derives from a moral judgment view of tax administration where certain taxpayers deserve to be relieved of IRS collection action. Mashaw's study demonstrates how the different models were in tension within the Social Security Administration and how that agency resolved the tension in favor of bureaucratic rationality. My study of the IRS response to the CDP provisions shows much the same result. As demonstrated in Part II, the IRS has gone far in suppressing the adversarial features implicit in CDP, and in administering CDP through what I call an inquisitorial paradigm and what Mashaw calls a bureaucratic rationality model.

The central promise of due process is the opportunity to be heard at a "meaningful time and in a meaningful manner." 320 The Supreme Court long ago decided that the rule of law embodied in the Due Process Clause does not require the government to give taxpayers a pre-deprivation hearing regarding tax collection. ${ }^{321}$ Only after a properly assessed tax is collected may the taxpayer invoke judicial process.

This promise of "meaningful" not only has a legal dimension, however, but also a moral one. It is, in essence, an issue of "voice." Distrust of the bureaucracy-of the Borg collective-inheres in American culture, which celebrates the autonomy of the individual in so many ways, one of which is the reliance on adversarial process. ${ }^{322}$ Indeed, just as Judge Friendly noted in the quotation that started this Article, the traditional check on agency discretion has been through the adversarial process provided by courts or administrative law systems modeled on the adversarial process paradigm. ${ }^{323}$ Because this paradigm depends on the litigants to provide the needed information, one must be either exceptionally adept at gathering and presenting evidence, or be able to hire someone to do it on his or her behalf.

Ironically, the adversarial check of judicial review is simply unavailable to the class of taxpayers we should worry about the most: the inarticulate can't-pays. ${ }^{324}$ By definition, they do not have the ability to gather the information necessary to trigger the exercise of discretion, much less to trigger a meaningful review. By definition, they do not have the money to hire someone to do it for them. ${ }^{325}$ These are serious barriers to voice. Nor are taxpayer assistance clinics able to serve anywhere close to a reasonable number of taxpayers. Not only do they serve only a small fraction of taxpayers in need but their assistance often comes too late in the process-when the

L. REV. 731 (2003).

319. See Camp, supra note 2.

320. Armstrong v. Manzo, 380 U.S. 545, 552 (1965).

321. Phillips v. Comm'r, 283 U.S. 589 (1931).

322. I discuss these ideas further in Camp, supra note 2, at 18-20. See also MASHAW, supra note 313, at 223 ("Bureaucracy is probably the most important of our negative symbols." (quoting THURMAN W. ARNOLD, THE SYMBOLS OF GOVERNMENT 209 (1941))).

323. See generally Henry J. Friendly, supra note 1 (reviewing the historical developments and understandings of the term "hearing" with respect to administrative agencies).

324. I do not worry about won't-pays: they do not have a claim to voice. And articulate can't-pays are generally able to interact with the bureaucracy well enough to be heard.

325. See infra app. tbl.1 (indicating that seventy-six percent of CDP cases are argued pro se). 
taxpayer's only remaining hope is judicial review-to matter. ${ }^{326}$ In short, adversarial process is not effective for the inarticulate or the poor. We owe them a better system.

The better approach to overseeing the tax collection classification decisions is to improve the inquisitorial process model used in tax collection. Like other bureaucracies, the tax bureaucracy is governed by rules. Tax administration in general, and tax collection in particular, must process taxpayers, returns, and accounts in bulk. To do that, the IRS uses systems of processes. Those systems are built on rules and, whether executed by humans or machines, rules are inherently both under- and overinclusive. ${ }^{327}$ In the tax collection context, the main rule is that delinquent taxpayers start out and remain won't-pays until the taxpayer provides the information to the right bureaucrat at the right time to be reclassified. Thus, the moral question, if you will, is how best to give taxpayers voice to help IRS employees properly mitigate the overand under-inclusive effect of rules in classifying taxpayers.

There are several ways to improve the system, both to reduce the need for taxpayers to prove their status as can't-pays and to help taxpayers interact with IRS employees when they do have to speak up. First, the IRS can use bulk processing to classify some groups of taxpayers as presumptive can't-pays. The algorithms that drive the queue already do this on the back end. The IRS could do it on the front end. For example, taxpayers who received the Earned Income Tax Credit (EITC) in a given year might be treated as presumptive can't-pays and automatically be placed in the status of "currently not collectible."

Second, the National Taxpayer Advocate has made the wonderful suggestion that the IRS kick certain groups of taxpayers into automatic audit reconsideration processes. ${ }^{328}$ Automatic audit reconsideration would occur in cases where there may be reason to distrust the assessment process (i.e., the liability determination), such as cases where the IRS has prepared a substitute for return and has had no contact from the taxpayer regarding the liability proposed on the substitute for return. Improving the taxpayer's voice in the tax determination process improves the accuracy of the collection process. In addition, it reduces the number of cases where the IRS is trying to collect taxes not actually owed.

Third, functions within the IRS that help give taxpayers voice in the system should be strengthened (i.e., funded), to help taxpayers gather and present the information necessary for the IRS systems to make the correct collection decision. The Offices of Appeals and the Taxpayer Advocate do this, the former on the individualized retail level and the latter on both the individual level and systemic level. ${ }^{329}$

326. In fiscal year 2008, the IRS funded 154 clinics. Hearing on Internal Revenue Service FY 2009 Budget Request Before the S. Comm. on Finance Serv. and General Gov't Comm. on Appropriations, 110th Cong. 17 (2008) (written statement of Nina Olson, National Taxpayer Advocate). About half of the clinics are located in law schools and service far fewer taxpayers than nonacademic clinics. The Tax Clinic at Texas Tech, for example, assisted approximately thirty-four taxpayers in calendar year 2007.

327. See generally Cass R. Sunstein, Problems with Rules, 83 CAL. L. REV. 953 (1995).

328. 2005 TAXPAYER ADVOCATE REPORT, supra note 75 , at 463 . The National Taxpayer Advocate actually suggests this idea be codified. $I d$. This would be an unhappy result since statutory provisions prevent an agency from reforming its practices as time and technology bring about new opportunities to imprave administration.

329. For a detailed review of the history and function of these offices, see Camp, supra note 
It is critically important that these two internal components remain internal and resist assuming an institutionally adversarial posture to the rest of the IRS. That is, many commentators believe that the concepts of tax "enforcement" and tax "service" are at opposite ends of the pole. ${ }^{330}$ This is a false dichotomy. As Ms. Olsen has repeatedly stressed, "taxpayer rights and higher rates of tax compliance can coexist and do not reflect opposing values." ${ }^{331}$ Inquisitorial due process is not necessarily about consolidation or dispersion of authority; it is as much or more about information management and evaluation. ${ }^{332}$

By virtue of their internal position within the agency, the Taxpayer Advocate Service and the Office of Appeals add multiple layers of value-value which cannot be replicated by any type of outside agency. First, taxpayers tend both to respond better and feel better about requests for information when the requests come from an Appeals Officer or from a Taxpayer Advocate, who they perceive are in positions to give immediate relief or help. ${ }^{333}$ This improves outcomes not only by improving quality of information in a way that cannot be matched by either the judiciary or any outside reviewing entity, but also by increasing taxpayers' respect for the system.

Second, the Office of Appeals and the Taxpayer Advocate are uniquely positioned as internal components to act as cultural counterweights to the enforcement mentality that makes it so difficult for collection employees to maintain the necessary perspective to carry out the IRS mission and not succumb to the false dichotomy between taxpayer rights and taxpayer compliance. One of the most valuable services these components provide to other IRS functions is education about better practices, both for gathering taxpayer information and processing it. In short, they can help field employees become better listeners.

Third, these offices add symbolic value. Professor Mashaw is the latest in a long list of scholars who note that bureaucracies have no effective symbolism to allay popular distrust. ${ }^{334}$ Both the Office of Appeals and the Taxpayer Advocate Service could provide such symbolism. The symbolism should not be architectural, such as housing the two functions in different physical facilities. That would diminish their ability to be

2 , at $93-103$.

330. See, e.g., Testimony Before the Joint Congressional Review on the Strategic Plans and Budget of the IRS, 109th Cong. (2005) (written testimony of Raymond T. Wagner, Jr., Chairman, IRS Oversight Board) (discussing "shifts in customer service and enforcement"); Practices and Procedures of the Internal Revenue Service: Hearing Before the S. Comm. on Finance, 105th Cong. 23 (1997) (statement of Joseph F. Lane, Chairman, Nat'l Gov't Relations Comm., The Nat'l Ass'n of Enrolled Agents) (suggesting that we "divide the IRS into two separate agencies, one for the taxpayer service, and the other for tax law compliance"); Gov'T ACCOUNTABILITY OFFICE, ASSESSMENT OF FISCAL YeAR 2006 BUDGET REQUEST 24 (2005), available at http://www.gao.gov/new.items/d05566.pdf (describing the "swinging pendulum, where enforcement gains are achieved at the cost of taxpayer service and vice versa"); Alvin Lurie, Killed with Kindness or How We Stopped Hating the IRS, 100 TAX NOTES 593 (July 28, 2003) (arguing enforcement should be the primary mission of the IRS); William Stevenson, IRS's Primary Focus on Service is the Right Way to Go, 99 TAX Notes 1850 (June 23, 2003).

331. 2004 TAXPAYER ADVOCATE REPORT, supra note 52, at 227.

332. See Camp, supra note 2, at 5-17.

333. See 2004 TAXPAYER ADVOCATE REPORT, supra note 52, at 460 ("Often Appeals Officers are more helpful and successful in eliciting information from and conversing with the taxpayer than [field IRS] employees.").

334. See MASHAW, supra note 313, at 222-27. 
internal cultural counterweights. Instead, the symbolism should arise from highly visible actions. For example, the Taxpayer Advocate has made a clever suggestion: that Congress give the Taxpayer Advocate Service the ability to provide de minimis "apology" payments to taxpayers who have been aggrieved by the system. ${ }^{335}$ Such payments, especially if prominently promoted in the media, would provide highly visible public reassurance that someone was watching out for the interests of the "people" against the "bureaucracy." Such authority should also be vested in the Office of Appeals.

Strengthening the ability of both the Office of Appeals and the Taxpayer Advocate to amplify and fine tune taxpayer voices within the collections system will be far more effective than judicial review at providing taxpayers a process that is meaningful, in all senses of the word. It would, at the same time, add value to tax administration by improving the classification decisions. It would answer the clamor for adversarial process. It would, in short, be a step towards a notion of inquisitorial due process. 


\section{APPENDIX}

To analyze how court review might add value, I ventured to extract the following variables from the cases: (1) whether the unpaid assessment was from a deficiency or a self reported liability; (2) whether the taxpayer was represented by counsel or acted pro se; (3) whether the trial court's disposition was appealed (and the result); (4) which type of court (Tax Court or District Court) performed the review; (5) whether the taxpayer raised frivolous, tax protestor-type arguments; (6) whether any court imposed sanctions on the taxpayer; (7) whether the taxpayer or government prevailed (any case where the government did not prevail was counted as a taxpayer victory, even if it was simply the court denying a dispositive motion); (8) whether the taxpayer's complaint was about the merits of the tax assessment or the collection procedure or both; (9) the date of the CDP notice; (10) the date of the Notice of Determination or other administrative disposition; and (11) the date of the trial court disposition and, if applicable, the appellate court disposition. The following table notes my basic findings.

Table 1. Basic CDP Statistics

\begin{tabular}{|l|c|c|c|c|c|c|c|c|}
\hline Year & 2000 & 2001 & 2002 & 2003 & 2004 & 2005 & 2006 & Total \\
\hline Records & 30 & 46 & 204 & 190 & 171 & 179 & 156 & 976 \\
\hline Deficiency & 15 & 9 & 82 & 76 & 52 & 69 & 48 & 351 \\
\hline Pro Se & 20 & 34 & 174 & 150 & 118 & 137 & 108 & 741 \\
\hline Appealed & 3 & 7 & 26 & 36 & 24 & 18 & 3 & 117 \\
\hline Opinion Type & & & & & & & & \\
\hline Tax Court & 10 & 12 & 19 & 16 & 20 & 13 & 14 & 104 \\
\hline Tax Court Memos & 7 & 13 & 80 & 92 & 66 & 77 & 61 & 396 \\
\hline Special Trial Judge & 0 & 1 & 7 & 9 & 28 & 26 & 23 & 94 \\
\hline District Court & 12 & 20 & 97 & 73 & 57 & 63 & 57 & 379 \\
\hline Bankruptcy Court & 1 & 0 & 1 & 0 & 0 & 0 & 0 & 2 \\
\hline Claims Court & 0 & 0 & 0 & 0 & 0 & 0 & 1 & 1 \\
\hline Protestor & 3 & 11 & 100 & 100 & 42 & 62 & 47 & 365 \\
\hline Lack of Jurisdiction & 13 & 18 & 92 & 66 & 21 & 29 & 30 & 269 \\
\hline Sanctions & 1 & 2 & 34 & 50 & 16 & 26 & 15 & 144 \\
\hline Taxpayer Victory & 3 & 1 & 5 & 4 & 21 & 18 & 11 & 64 \\
\hline Complaint & & & & & & & & \\
\hline Procedural & 10 & 9 & 44 & 49 & 71 & 42 & 78 & 303 \\
\hline Liability & 16 & 34 & 130 & 106 & 38 & 50 & 31 & 405 \\
\hline Both & 4 & 3 & 27 & 34 & 62 & 86 & 47 & 263 \\
\hline
\end{tabular}


Table 2 Key

Win Type Column
$\mathrm{M}=$ Win on the Merits
$\mathrm{P}=$ Win on Procedure
$\mathrm{I}=$ Interstitial Win
$\mathrm{L}=$ IRS Error in Liability Decision
$\mathrm{C}=$ IRS Error in Collection Decision
For example, "PC" means a procedural win in a
collection decision where the IRS was in error.
Notes Column
TP $=$ Taxpayer
SJ $=$ Summary Judgment
TRFP = Trust Fund Recovery Penalty $(\$ 6672)$
OIC = Offer In Compromise
SOL $=$ Statute of Limitations

Table 2. Taxpayer "Victories" Sorted by Year of Decision, Then by Taxpayer Name

\begin{tabular}{|c|c|c|c|}
\hline Case Citation & $\begin{array}{l}\text { Win } \\
\text { Type }\end{array}$ & Pro Se & Notes \\
\hline $\begin{array}{l}\text { Butti v. Comm'r, } 91 \text { T.C.M. } \\
\text { (CCH) } 967 \text { (2006). }\end{array}$ & PC & Yes & Remand to allow TP to contest liability \\
\hline $\begin{array}{l}\text { Calafati v. Comm'r, } 127 \text { T.C. } 219 \\
(2006) \text {. }\end{array}$ & PC & No & IRS had to give TP face-to-face hearing \\
\hline $\begin{array}{l}\text { Crawford v. United States, } 422 \text { F. } \\
\text { Supp. 2d } 1209 \text { (D. Nev. 2006). }\end{array}$ & PC & No & TFRP \\
\hline $\begin{array}{l}\text { Gerhart v. United States, No. 04- } \\
\text { CV-04942, } 2006 \text { U.S. Dist. LEXIS } \\
54549 \text { (E.D. Pa. May 24, 2006). }\end{array}$ & IC & Yes & TFRP; TP survived Motion to Dismiss \\
\hline $\begin{array}{l}\text { Harris v. Comm'r, } 92 \text { T.C.M. } \\
\text { (CCH) } 217 \text { (2006). }\end{array}$ & MC & Yes & IRS abused discretion by rejecting the OIC \\
\hline $\begin{array}{l}\text { Manko v. Comm'r, } 126 \text { T.C. } 195 \\
(2006) .\end{array}$ & ML & No & IRS failed to issued necessary deficiency \\
\hline $\begin{array}{l}\text { Moore v. Comm'r, } 92 \text { T.C.M. } \\
\text { (CCH) } 131 \text { (2006). }\end{array}$ & $\mathrm{PC}$ & No & $\begin{array}{l}\text { Remand for new hearing because of ex parte } \\
\text { taint }\end{array}$ \\
\hline $\begin{array}{l}\text { Oman v. Comm'r, } 92 \text { T.C.M. } \\
(\mathrm{CCH}) 372(2006) \text {. }\end{array}$ & $\mathrm{MC}$ & Yes & $\begin{array}{l}\text { Remand for clarification and further } \\
\text { consideration }\end{array}$ \\
\hline $\begin{array}{l}\text { Pineda v. Comm'r, No. 3081-05S, } \\
2006 \text { WL } 469652 \text { (T.C. Feb. } 27 \text {, } \\
\text { 2006). }\end{array}$ & $\mathrm{PC}$ & Yes & $\begin{array}{l}\text { Split; IRS must consider installment agreement } \\
\text { or other collection alternative on remand }\end{array}$ \\
\hline $\begin{array}{l}\text { Sampson v. Comm'r, No. } 4170 \text { - } \\
\text { 05S, 2006 WL } 1228593 \text { (T.C. May } \\
8,2006 \text { ). }\end{array}$ & PC & Yes & $\begin{array}{l}\text { Remand to consider using a future income } \\
\text { agreement as part of taxpayer's OIC }\end{array}$ \\
\hline $\begin{array}{l}\text { Sherer v. Comm'r, } 91 \text { T.C.M } \\
\text { (CCH) } 759 \text { (2006). }\end{array}$ & PL & Yes & No liability for taxpayer \\
\hline
\end{tabular}




\begin{tabular}{|c|c|c|c|}
\hline Case Citation & $\begin{array}{l}\text { Win } \\
\text { Type }\end{array}$ & Pro Se & Notes \\
\hline $\begin{array}{l}\text { Bennett v. Comm'r, No. } 6291 \text { - } \\
\text { 03S, 2005 WL } 1405977 \text { (T.C. June } \\
\text { 16, 2005). }\end{array}$ & ML & Yes & Split; TP won partial Innocent Spouse relief \\
\hline $\begin{array}{l}\text { Beverly v. Comm'r, No. } 10774- \\
\text { 03L, 2005 WL } 544842 \text { (T.C. Mar. } \\
7,2005 \text { ). }\end{array}$ & MC & Yes & Duplicate Relief: Automatic Stay violation \\
\hline $\begin{array}{l}\text { Bo v. Comm'r, } 89 \text { T.C.M. (CCH) } \\
1474 \text { (2005). }\end{array}$ & ML & Yes & Split; TP won some abatements, not others \\
\hline $\begin{array}{l}\text { Dibble v. United States, No. 1:05- } \\
\text { CV-201, } 2005 \text { WL } 3556073 \text { (W.D. } \\
\text { Mich. Dec. 29, 2005). }\end{array}$ & IC & Yes & Split; TP partially survived dismissal \\
\hline $\begin{array}{l}\text { Electro, Inc. v. Comm'r, No. } 04 \text { - } \\
113-\mathrm{KI}, 2005 \text { WL } 43870 \text { (D. Or. } \\
\text { Jan. } 7,2005 \text { ). }\end{array}$ & IC & No & TP survived dismissal \\
\hline $\begin{array}{l}\text { Freije v. Comm'r, } 125 \text { T.C. } 14 \\
\text { (2005). }\end{array}$ & MC & Yes & $\begin{array}{l}\text { Remand to recalculate liabilities in light of } \\
\text { improper assessments and application of } \\
\text { payments }\end{array}$ \\
\hline $\begin{array}{l}\text { Garage v. United States, No. Civ. } \\
04-1133 \text { (HAA), } 2005 \text { WL } \\
3610064 \text { (D. N.J. Nov. 22, 2005). }\end{array}$ & $\mathbf{P C}$ & No & $\begin{array}{l}\text { Remand for face-to-face hearing; same attomey } \\
\text { as Cavanaugh v. United States, No. 03-250, } \\
2004 \text { WL } 880442 \text { (D.N.J. Mar. 23, 2004), } \\
\text { which had the same outcome }\end{array}$ \\
\hline $\begin{array}{l}\text { Hayes v. Comm'r, No. 7699-02L, } \\
2005 \text { WL } 697962 \text { (T.C. Mar. 28, } \\
\text { 2005). }\end{array}$ & ML & Yes & $\begin{array}{l}\text { Split; TP won one year, IRS won two years; } \\
\text { similar to Rivera v. Comm'r, No. 2401-01L, } \\
2003 \text { WL } 345341 \text { (T.C. Feb. 14, 2003) }\end{array}$ \\
\hline $\begin{array}{l}\text { Hendricks v. Comm'r, No. } 11416 \text {, } \\
2005 \text { WL } 758043 \text { (T.C. Apr. 5, } \\
\text { 2005). }\end{array}$ & ML & No & Duplicative Relief: Innocent Spouse \\
\hline $\begin{array}{l}\text { Jackson v. Comm'r, No. } 525-04 \text { S, } \\
2005 \text { WL } 342102 \text { (T.C. Feb. 14, } \\
\text { 2005). }\end{array}$ & ML & Yes & $\begin{array}{l}\text { Split; TP won abatement of some interest; IRS } \\
\text { could collect other interest, penalties }\end{array}$ \\
\hline $\begin{array}{l}\text { Johnson v. Comm'r, No. } 20594 \\
\text { 03S, 2005 WL } 883701 \text { (T.C. Apr. } \\
\text { 18, 2005). }\end{array}$ & IC & Yes & Homeless TP survived SJ \\
\hline $\begin{array}{l}\text { Lites v. Comm'r, } 90 \text { T.C.M. } \\
\text { (CCH) } 191(2005) \text {. }\end{array}$ & PC & No & $\begin{array}{l}\text { Split; no abatement but remand for Appeals to } \\
\text { consider installment offer }\end{array}$ \\
\hline $\begin{array}{l}\text { Mesa Oil, Inc. v. United States, } \\
467 \text { F.3d } 1252 \text { (10th Cir. 2006). }\end{array}$ & $\mathrm{PC}$ & No & Split; TP won new hearing \\
\hline $\begin{array}{l}\text { Julian W. Mandody, } 89 \text { T.C.M. } \\
\text { (CCH) } 1445 \text { (2005). }\end{array}$ & IC & Yes & $\begin{array}{l}\text { TP survived SJ motion; allowed to introduce } \\
\text { new evidence; pre-Robinette }\end{array}$ \\
\hline $\begin{array}{l}\text { Norris v. Comm'r, } 90 \text { T.C.M. } \\
\text { (CCH) } 381 \text { (2005). }\end{array}$ & MC & Yes & IRS must restore Installment Agreement \\
\hline $\begin{array}{l}\text { Richard v. Comm'r, No. 1216- } \\
\text { 03S, 2005 WL 2591956 (T.C. Oct. } \\
\text { 13, 2005). }\end{array}$ & ML & No & SOL; assessment late because no fraud \\
\hline
\end{tabular}




\begin{tabular}{|c|c|c|c|}
\hline Case Citation & $\begin{array}{l}\text { Win } \\
\text { Type }\end{array}$ & Pro Se & Notes \\
\hline $\begin{array}{l}\text { Smith v. Comm'r, } 124 \text { T.C. } 36 \\
(2005) \text {. }\end{array}$ & MC & No & Duplicative Relief: Automatic Stay Violation \\
\hline $\begin{array}{l}\text { Zapara v. Comm'r, } 124 \text { T.C. } 223 \\
(2005) .\end{array}$ & ML & Yes & $\begin{array}{l}\text { IRS must credit TP for value of seized stock as } \\
\text { of the day the IRS should have sold it but did } \\
\text { not }\end{array}$ \\
\hline $\begin{array}{l}\text { Borges v. United States, } 317 \text { F. } \\
\text { Supp. 2d } 1276 \text { (D.N.M. 2004). }\end{array}$ & PL & No & Duplicative Relief: TFRP \\
\hline $\begin{array}{l}\text { Cavanaugh, No. 03-250, } 2004 \text { WL } \\
880442 \text { (D.N.J. Mar. 23, 2004). }\end{array}$ & PC & No & $\begin{array}{l}\text { Remand for new hearing; same attomey as } \\
\text { Garage v. United States, No. Civ. 04-1133 } \\
\text { (HAA), 2005 WL } 3610064 \text { (D.N.J. 2005) }\end{array}$ \\
\hline $\begin{array}{l}\text { Chavez v. United States, No. } \\
\text { Civ.EP-03-CA-303(KC), } 2004 \text { WL } \\
1124914 \text { (W.D. Tex. May 18, } \\
\text { 2004). }\end{array}$ & $\mathrm{MC}$ & No & TFRP \\
\hline $\begin{array}{l}\text { Chocallo v. Comm'r, No. } 12695- \\
\text { 02L, 2004 WL } 1435478 \text { (T.C. June } \\
\text { 28, 2004). }\end{array}$ & PL & Yes & $\begin{array}{l}\text { Remand to allow TP to contest liability (TP } \\
\text { succeeded on remand) }\end{array}$ \\
\hline $\begin{array}{l}\text { Cooper v. Comm'r, } 87 \text { T.C.M. } \\
\text { (CCH) } 1033 \text { (2004). }\end{array}$ & IC & No & TP survived SJ \\
\hline $\begin{array}{l}\text { Cox v. United States, No. CIV-04- } \\
\text { 0085-F, } 2004 \text { WL } 3080342 \text { (W.D. } \\
\text { Okla. Nov. 12, 2004). }\end{array}$ & PC & No & TFRP \\
\hline $\begin{array}{l}\text { Creel v. Comm'r, } 419 \text { F.3d } 1135 \\
\text { (11th Cir. 2005). }\end{array}$ & ML & No & IRS could not collect penalties, interest \\
\hline $\begin{array}{l}\text { Haws v. Comm'r, No. 19830-02S, } \\
2004 \text { WL } 728916 \text { (T.C. Apr. } 6 \text {, } \\
\text { 2004). }\end{array}$ & $\mathrm{PC}$ & No & $\begin{array}{l}\text { Remand to determine whether prior installment } \\
\text { agreement covering tax year to be collected had } \\
\text { been terminated }\end{array}$ \\
\hline $\begin{array}{l}\text { Fowler v. Comm'r, No. 6650-02L, } \\
2004 \text { WL } 1559188 \text { (T.C. July 13, } \\
\text { 2004). }\end{array}$ & $\mathrm{MC}$ & Yes & $\begin{array}{l}\text { Split; IRS should have accepted OIC, but could } \\
\text { still file NFTLs }\end{array}$ \\
\hline $\begin{array}{l}\text { Hudson v. IRS, No. 03-CV-172, } \\
2004 \text { WL } 1006266 \text { (N.D.N.Y. } \\
\text { Mar. 25, 2004). }\end{array}$ & ML & No & $\begin{array}{l}\text { Split; TP won abatement of interest on TFRP; } \\
\text { IRS won right to collect reduced TFRP liability }\end{array}$ \\
\hline $\begin{array}{l}\text { Israel v. Comm'r, } 86 \text { T.C.M. } \\
\text { (CCH) } 23 \text { (2003). }\end{array}$ & ML & Yes & $\begin{array}{l}\text { Split; IRS had not properly assessed one tax } \\
\text { year; IRS got green light for two other years }\end{array}$ \\
\hline $\begin{array}{l}\text { Molina v. Comm'r, No. } 4026-03 \text { L, } \\
2004 \text { WL } 2538097 \text { (T.C. Nov. 10, } \\
\text { 2004). }\end{array}$ & ML & Yes & Reduced liability \\
\hline $\begin{array}{l}\text { Montgomery v. Comm'r, } 122 \text { T.C. } \\
\text { l (2004). }\end{array}$ & PL & No & Remand to allow TP to contest liability \\
\hline $\begin{array}{l}\text { Pollack v. United States, } 327 \text { F. } \\
\text { Supp. 2d } 907 \text { (W.D. Tenn. 2004). }\end{array}$ & IC & No & $\begin{array}{l}\text { Split; TP survived SJ as to collection decision } \\
\text { but lost } \mathrm{SJ} \text { as to liability decision }\end{array}$ \\
\hline
\end{tabular}




\begin{tabular}{|c|c|c|c|}
\hline Case Citation & $\begin{array}{l}\text { Win } \\
\text { Type }\end{array}$ & Pro Se & Notes \\
\hline $\begin{array}{l}\text { Ramirez v. Comm'r, No. } 14154 \text { - } \\
\text { 02S, } 2004 \text { WL } 766432 \text { (T.C. Apr. } \\
\text { 14, 2004). }\end{array}$ & $\mathrm{PC}$ & Yes & Remand: IRS must reconsider OIC \\
\hline $\begin{array}{l}\text { Ratke v. Comm'r, No. } 9641-01 \text { L, } \\
2004 \text { WL } 585810 \text { (T.C. Mar. 25, } \\
\text { 2004). }\end{array}$ & $\mathrm{ML}$ & No & $\begin{array}{l}\text { IRS bound by prior settlement agreement as to } \\
\text { liability }\end{array}$ \\
\hline $\begin{array}{l}\text { Robertson v. Comm'r, No. 5221- } \\
\text { 03, } 2004 \text { WL } 2153937 \text { (T.C. Sept. } \\
\text { 27, 2004). }\end{array}$ & IL & Yes & $\begin{array}{l}\text { Split; TP lost SJ on four tax periods but } \\
\text { survived SJ on fifth tax period to allow TP to } \\
\text { contest self reported liability }\end{array}$ \\
\hline $\begin{array}{l}\text { Law Offices of Neal Sanders v. } \\
\text { Comm'r, No. 02-2060, 2004 WL } \\
838058 \text { (W.D. Pa. Mar. 9, 2004). }\end{array}$ & $\mathbf{I L}$ & No & $\begin{array}{l}\text { Split; TP count one dismissed, but TP survived } \\
\text { SJ; TFRP }\end{array}$ \\
\hline $\begin{array}{l}\text { Skrizowski v. Comm'r, } 88 \text { T.C.M. } \\
\text { (CCH) } 336 \text { (2004). }\end{array}$ & MC & No & $\begin{array}{l}\text { IRS must remove nominee liens; TP also won } \\
\text { remand for IRS to consider OIC }\end{array}$ \\
\hline $\begin{array}{l}\text { Thorpe v. Comm'r, No. 6209-03S, } \\
2004 \text { WL } 1658385 \text { (T.C. July 26, } \\
\text { 2004). }\end{array}$ & PL & Yes & $\begin{array}{l}\text { Duplicate Relief: Innocent Spouse; TP won } \\
\text { remand }\end{array}$ \\
\hline $\begin{array}{l}\text { Zelaya v. Comm'r, No. } 16148- \\
\text { 03S, 2004 WL } 2727777 \text { (T.C. Dec. } \\
1,2004 \text { ). }\end{array}$ & ML & Yes & $\begin{array}{l}\text { Court found TP's signature on duplicate refund } \\
\text { check to be forged; no liability }\end{array}$ \\
\hline $\begin{array}{l}\text { Harrell v. Comm'r, No. } 4063-02 L \text {, } \\
2003 \text { WL } 22137919 \text { (T.C. Sept. } \\
\text { 17, 2003). }\end{array}$ & PC & No & $\begin{array}{l}\text { Remand to allow TP a second chance to accept } \\
\text { an IRS modification to proposed Installment } \\
\text { Agreement }\end{array}$ \\
\hline $\begin{array}{l}\text { Keene v. Comm'r, } 121 \text { T.C. } 8 \\
\text { (2003). }\end{array}$ & $\mathrm{PC}$ & Yes & Remand to allow TP to record hearing \\
\hline $\begin{array}{l}\text { Rivera v. Comm'r, No. 2401-01L, } \\
2003 \text { WL } 345341 \text { (T.C. Feb. 14, } \\
\text { 2003). }\end{array}$ & PC & Yes & $\begin{array}{l}\text { Split; TP got remand for some years, not for } \\
\text { others }\end{array}$ \\
\hline $\begin{array}{l}\text { Tatum v. Comm'r, No. 1126-01L, } \\
2003 \text { WL } 1918914 \text { (T.C. Apr. 22, } \\
\text { 2003). }\end{array}$ & PL & No & Remand to allow TP to contest liability \\
\hline $\begin{array}{l}\text { Erickson v. United States, No. C- } \\
\text { 01-20798-JE, } 2002 \text { U.S. Dist. } \\
\text { LEXIS } 8963 \text { (T.C. Mar. 14, 2002). }\end{array}$ & PC & Yes & Remand for new hearing \\
\hline $\begin{array}{l}\text { Hoffman v. Comm'r, } 119 \text { T.C. } 140 \\
(2002) .\end{array}$ & ML & No & $\begin{array}{l}\text { SOL barred assessment of tax sought to be } \\
\text { collected }\end{array}$ \\
\hline $\begin{array}{l}\text { Moraldi v. United States, No. CV- } \\
\text { S-01-1296 RLH RJJ, } 2002 \text { WL } \\
1482296 \text { (D. Nev. May 10, 2002). }\end{array}$ & IL & No & Duplicative Relief: TP survived SJ; TFRP \\
\hline $\begin{array}{l}\text { Silver v. Smith, No. 01-CV-6193L, } \\
2002 \text { WL } 31367926 \text { (W.D.N.Y. } \\
\text { Sept. 5, 2002). }\end{array}$ & $\mathbf{P C}$ & Yes & $\begin{array}{l}\text { Split; TP won remand for new CDP hearing on } \\
\text { one tax period; IRS got green light to collect } \\
\text { two others; like Rivera }\end{array}$ \\
\hline $\begin{array}{l}\text { Wright v. Comm'r, No. } 6240-01 \text { L, } \\
2002 \text { WL } 31875118 \text { (T.C. Dec. } 26 \text {, } \\
2002 \text { ). }\end{array}$ & ML & Yes & $\begin{array}{l}\text { Reduced liability; this case was vacated and } \\
\text { remanded by Wright v. Comm'r, } 381 \text { F.3d } 41 \\
\text { (2d Cir. 2004) }\end{array}$ \\
\hline
\end{tabular}




\begin{tabular}{|l|l|l|l|}
\hline Case Citation & $\begin{array}{l}\text { Win } \\
\text { Type }\end{array}$ & Pro Se & Notes \\
\hline $\begin{array}{l}\text { Tkac v. Comm'r, No. 3556-00S, } \\
\text { 2001 WL 1922701 (T.C. Nov. 14, } \\
\text { 2001). }\end{array}$ & ML & Yes & $\begin{array}{l}\text { Split; TP got IRS to concede income tax } \\
\text { liability but not frivolous return penalties; } \\
\text { example of collateral benefit of court hearing: } \\
\text { IRS attorney reviews case }\end{array}$ \\
\hline $\begin{array}{l}\text { Mesa Oil, Inc. v. United States, } \\
\text { No. Civ.A. 00-B-851, 2000 WL } \\
\text { 1745280 (D. Colo. Nov. 21, 2000). }\end{array}$ & PC & No & $\begin{array}{l}\text { Remand for new hearing to produce a record } \\
\text { sufficient for court review }\end{array}$ \\
\hline $\begin{array}{l}\text { Meyer v. Comm'r, 115 T.C. 417 } \\
\text { (2000). }\end{array}$ & MC & Yes & $\begin{array}{l}\text { Voided Collection Action; pre-Lunsford; } \\
\text { overruled by 117 T.C. 159 (2001); abrogated } \\
\text { by 117 T.C. 204 (2001) }\end{array}$ \\
\hline $\begin{array}{l}\text { MRCA Info. Servs. v. United } \\
\text { States, 145 F. Supp. 2d 194 (D. } \\
\text { Conn. 2000). }\end{array}$ & PC & No & $\begin{array}{l}\text { Remand for new hearing with different Appeals } \\
\text { Officer }\end{array}$ \\
\hline
\end{tabular}

Figure 1 demonstrates that a higher proportion of CDP cases in Tax Court are pro se compared to those that went to district courts. The main reason for this is that district courts had jurisdiction over the employment tax cases where business taxpayers are far more likely to be represented by counsel.

Figure 1: Pro Se Cases

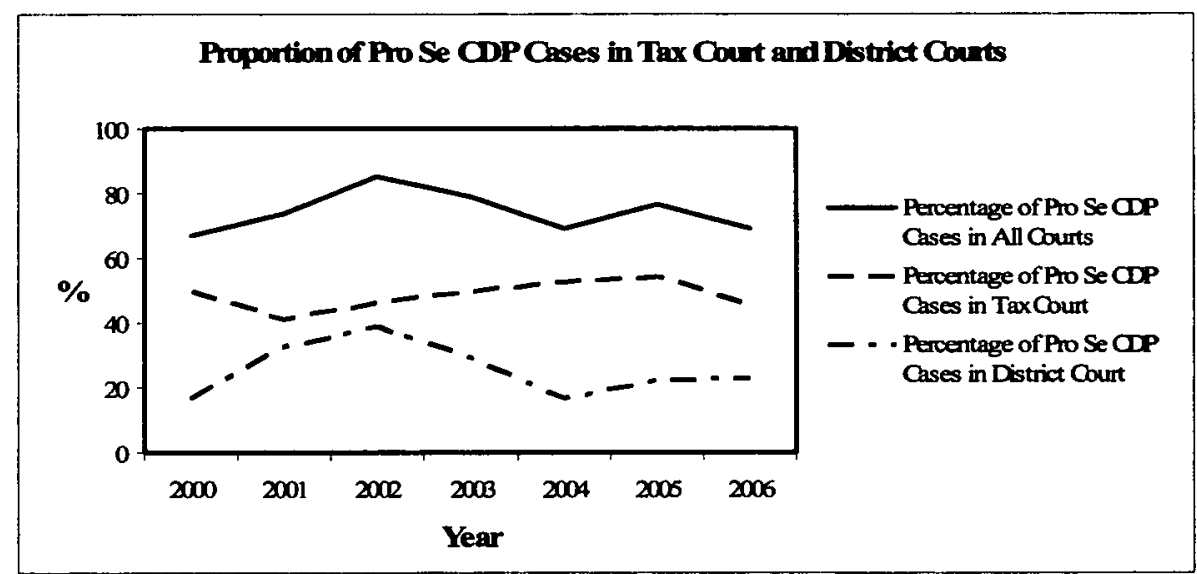

Although CDP is meant to protect taxpayers from abusive collection decisions, it allows a taxpayer to contest a tax liability whenever the taxpayer did not have a prior opportunity to do so. ${ }^{336}$ The Tax Court, in Montgomery $v$. Commissioner, ${ }^{337}$ held that even where the taxpayer had self reported a liability, the taxpayer could contest the same in a CDP hearing because, by definition, the taxpayer had not had a prior opportunity to contest it. Accordingly, it is not surprising to see many taxpayers attempt to contest their liability either as the sole issue or in conjunction with a protest about how the IRS is proceeding to collect it.

336. See I.R.C. $\S 6330(\mathrm{c})(2)(\mathrm{B})(2000)$.

337. 122 T.C. $1,36(2004)$. 
Figure 2. Types of Issues Raised

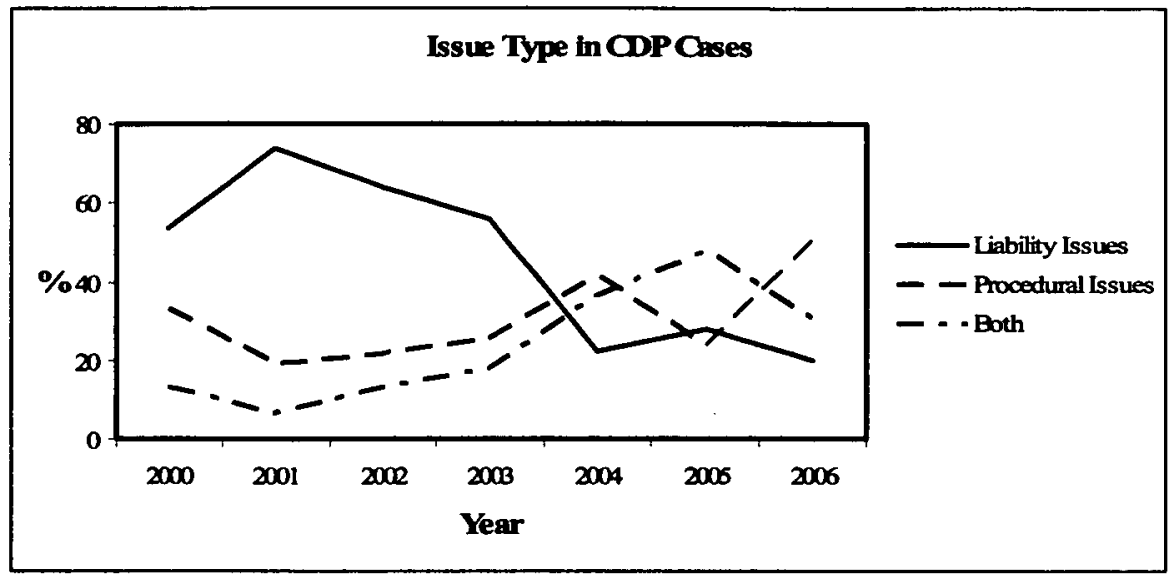

The following figure tracks how many of the cases decided in a given year were appealed to a circuit court, which is not the same as the number of appeals lodged in a given year. The data shows a decreasing number of CDP taxpayers taking their trial court losses up on appeal. This decrease correlates with the decrease in tax protestor cases.

Figure 3. Appeals to Circuit Courts of Appeal

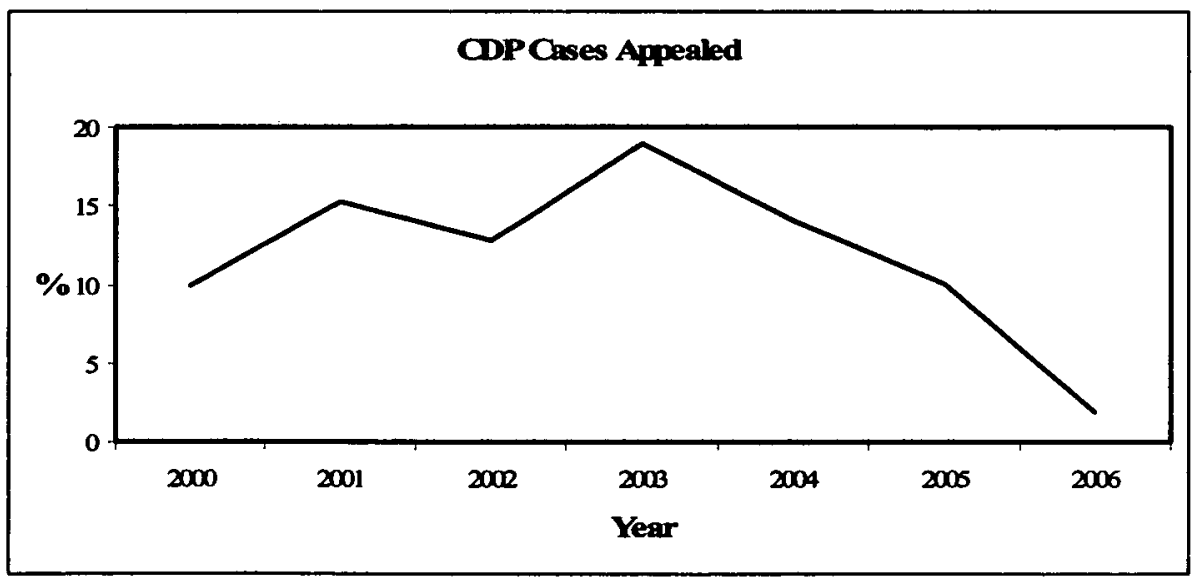

